\title{
Current Advances in the Treatment of BRAF-Mutant Melanoma
}

\author{
Hima Patel ${ }^{1,+}$, Nour Yacoub ${ }^{2,+}$, Rosalin Mishra ${ }^{1} \mathbb{D}$, Aaron White $^{3} \mathbb{D}$, Long Yuan ${ }^{1}$, \\ Samar Alanazi ${ }^{1}$ and Joan T. Garrett ${ }^{1, *}$ \\ 1 James. L. Winkle College of Pharmacy, University of Cincinnati, Cincinnati, OH 45243, USA; \\ patel2h2@mail.uc.edu (H.P.); mishrarn@ucmail.uc.edu (R.M.); yuanlg@mail.uc.edu (L.Y.); \\ alanazsa@mail.uc.edu (S.A.) \\ 2 College of Medicine, Northeast Ohio Medical University, Rootstown, OH 44274, USA; nyacoub@neomed.edu \\ 3 College of Medicine, University of Cincinnati, Cincinnati, OH 45243, USA; white3ai@mail.uc.edu \\ * Correspondence: garrejn@ucmail.uc.edu \\ + These authors contributed equally to this work.
}

Received: 7 January 2020; Accepted: 14 February 2020; Published: 19 February 2020

\begin{abstract}
Melanoma is the most lethal form of skin cancer. Melanoma is usually curable with surgery if detected early, however, treatment options for patients with metastatic melanoma are limited and the five-year survival rate for metastatic melanoma had been 15-20\% before the advent of immunotherapy. Treatment with immune checkpoint inhibitors has increased long-term survival outcomes in patients with advanced melanoma to as high as 50\% although individual response can vary greatly. A mutation within the MAPK pathway leads to uncontrollable growth and ultimately develops into cancer. The most common driver mutation that leads to this characteristic overactivation in the MAPK pathway is the B-RAF mutation. Current combinations of BRAF and MEK inhibitors that have demonstrated improved patient outcomes include dabrafenib with trametinib, vemurafenib with cobimetinib or encorafenib with binimetinib. Treatment with BRAF and MEK inhibitors has met challenges as patient responses began to drop due to the development of resistance to these inhibitors which paved the way for development of immunotherapies and other small molecule inhibitor approaches to address this. Resistance to these inhibitors continues to push the need to expand our understanding of novel mechanisms of resistance associated with treatment therapies. This review focuses on the current landscape of how resistance occurs with the chronic use of BRAF and MEK inhibitors in BRAF-mutant melanoma and progress made in the fields of immunotherapies and other small molecules when used alone or in combination with BRAF and MEK inhibitors to delay or circumvent the onset of resistance for patients with stage III/IV BRAF mutant melanoma.
\end{abstract}

Keywords: melanoma; metastatic; resistance; BRAF; immunotherapy

\section{Introduction}

Melanoma is the uncontrollable division of melanocytes located within the deep layer of the epidermis [1]. Although invasive melanoma is the third most common type of skin cancer, it is the most serious compared to its other two counterparts- basal cell carcinoma and squamous cell carcinoma. The American Cancer Society estimates that in 2019 there will be 96,480 new cases of melanoma diagnosed accompanied by 7,230 expected deaths. The five-year survival rate for metastatic melanoma has been 15-20\% [2], although these statistics are rapidly improving with the success of immune checkpoint inhibitors. Treatment with immune checkpoint inhibitors demonstrated substantial clinical efficacy along with long-term survival outcomes in patients with advanced melanoma [3-5]. There are several clinical trials such as KEYNOTE-002, CheckMate067 and CheckMate064, which validate these findings, as detailed in Table 1. 
An important risk factor for melanoma is exposure to direct and chronic ultraviolet (UV) radiation which, increases the risk for DNA damage and leads to genetic changes. Familial history is also one of the risk factors for developing melanoma, with cyclin-dependent kinase inhibitor 2A (CDKN2A) and cyclin-dependent kinase 4 (CDK4) being the most common heritable mutations [1]. Germ-line polymorphisms of the melanocortin-1 receptor (MC1R) also confers susceptibility due to its ability to control the level of skin pigmentation in response to UV radiation $[2,6]$.

The molecular changes occurring in the progression of melanoma serve as points for therapeutic interference. Typically, the preliminary change of a melanocyte into a benign nevus remains controlled and is non-cancerous. However, some molecular changes can lead to overactivation of growth regulatory pathways, such as the mitogen-activated protein kinase (MAPK) signaling pathway [2]. The MAPK pathway is crucial in relaying extracellular signals in order to keep a balance of growth/proliferation and apoptosis within the cell. A mutation within MAPK pathway leads to uncontrollable growth and ultimately develops into cancer [7]. The most common driver mutation that leads to this characteristic overactivation in the MAPK pathway is the B-RAF mutation [2]. Raf is a family of oncogenic serine-threonine protein kinases within the MAPK pathway with three isoforms: A-RAF, B-RAF, and C-RAF $[7,8]$. B-RAF-mutant melanoma accounts for nearly 50\% of metastatic melanoma cases. Substitution of valine (V) for glutamic acid (E) at amino acid position 600 (V600E) represents $84.6 \%$ of the B-RAF mutations. A second common substitution of valine (V) for lysine $(\mathrm{K})$ at amino acid position 600 (V600K), representating 7.7\% of the B-RAF mutations [9]. B-RAF mutant melanoma is typically found in younger patients and is characterized by a superficial spreading tumor or nodular tumor that can be found in areas without chronic sun exposure. It has a higher chance of metastasizing into brain along with a shorter survival time as compared to the non-BRAF mutant melanoma. A B-RAF mutation alone may not contribute to the development of melanoma; but accompanying driver mutations in tumor suppressor genes are commonly indispensable leading to the development of malignant melanoma [9].

Several studies have addressed the need for molecular testing with respect to B-RAF mutations in order to tailor the best course of treatment available for each patient. $[9,10]$. Treatment options include surgery, immunotherapy, targeted therapy, chemotherapy, inclusion in a clinical trial and radiation [11]. Stage I and II melanoma can typically be surgically excised in concert with a sentinel lymph node biopsy if there is concern for metastasis. Stage III and IV melanoma require more systemic interventions due to the aggressiveness of the tumor and increased tumor burden [8]. The current standard of care for a patient diagnosed with B-RAF mutant metastatic melanoma is to first consider eligibility for a metastasectomy. Regardless of qualifications for the metastasectomy, the next step is to design a treatment regimen with either checkpoint inhibition immunotherapy or a molecularly targeted therapy $[9,10]$.

Current targeted therapies include a combination of B-RAF and MEK inhibitors. Vemurafenib was the first FDA-approved B-RAF inhibitor in 2011, followed by approval of dabrafenib in 2013 [8]. The most recent FDA-approved B-RAF inhibitor is encorafenib, approved in 2018 [12]. In parallel with the discovery and use of B-RAF inhibitors opened up the avenue for development of MEK inhibitors, targeting a molecule downstream of the B-RAF protein. The first MEK-inhibitor, trametinib, was approved by FDA in 2013, followed by approval of cobimetinib in 2015 [8]. Another recently FDA-approved MEK inhibitor was binimetinib [12]. Current combinations of BRAF and MEK inhibitors that have demonstrated improved patient outcomes include dabrafenib with trametinib, vemurafenib with cobimetinib or encorafenib with binimetinib [13]. Treatment with BRAF and MEK inhibitors has met with some challenges as patient responses began to drop due to the development of resistance to these inhibitors which paved the way for development of immunotherapies and other small molecule inhibitor approaches to address this.

Current immunotherapies include the anti-cytotoxic T-lymphocyte antigen 4 antibody (anti-CTLA-4) and two anti-programmed death protein 1 antibodies (anti-PD1) [8]. Current preclinical and clinical trials are underway to determine the efficacy and benefits of combining immunotherapy 
treatment regimen alone or in combination with BRAF and MEK inhibitors for treatment of patients with BRAF mutant melanoma [13-16]. New avenues exploring the possible combination therapies of BRAF/MEK inhibitors with immunotherapy drugs are being tested. Combination therapies are not only limited to MAPK pathway targeted therapies plus immunotherapy but have expanded to include other molecules such as AXL and ROS that have a role in the development of drug resistance. These have emerged as alternative treatment options for treating metastatic melanoma patients. Preclinical and clinical trials evaluating the efficacy of various PI3K and CDK4/6 inhibitors in combination with BRAF and MEK inhibitors are also initiated [17-22].

This review focuses on the current landscape of resistance with the chronic use of BRAF and MEK inhibitors in BRAF -mutant melanoma and progress made in the fields of immunotherapies and other small molecules when used alone or in combination with BRAF and MEK inhibitors to delay or circumvent the onset of resistance for patients with stage III/IV melanoma.

\section{Mechanisms of Resistance}

The development and use of the BRAF targeted inhibitors, Vemurafenib and dabrafenib, has improved the treatment arena for patients with metastatic melanoma. However, over half of patients treated with these single agent inhibitors begin to show signs of tumor recurrence within 6 to 7 months of treatment $[23,24]$. Several mechanisms of drug resistance have been proposed. There are two general types of resistance-primary resistance/intrinsic resistance and secondary or acquired resistance. Intrinsic resistance refers to those patients who do not respond to any type of BRAF inhibitor therapy and accounts for approximately 15\% of patients [25]. Acquired resistance, refers to those patients who show tumor regression after an initial positive response to therapy and this is commonly observed in most melanoma patients [26].

\subsection{Intrinsic Resistance}

PTEN is a negative regulator of phosphoinositde 3-kinase (PI3K) and loss of PTEN can lead to an upregulation of the PI3K/Akt pathway whose activation can explain tumor resistance [27,28]. Loss of PTEN alone does not confer a resistance state; it is typically accompanied with Akt phosphorylation and activation [26,29]. Cyclin D1 amplification (CCND1) is observed in about 15-20\% of all BRAF-mutant melanoma [30,31]. CCND1 alone can accelerate the resistance in BRAF-mutant melanoma and is intensified when there is both cyclin D1 overexpression along with a cyclin dependent kinase-4 (CDK4) mutation [32].

Neurofibromin-1 (NF1) is a tumor suppressor and a negative regulator of RAS. Loss of NF1 is typically seen in $14 \%$ of melanoma cases and leads to activation of RAS and other downstream pathways including the MAPK and PI3K-Akt [26,33]. Loss of NF1 can also mediate resistance to RAF and MEK inhibitors [34].

RAC1 is part of the Rho family of small GTP binding proteins. Mutations in RAC1 are found in $4-9 \%$ of patients and is the third "hotspot" mutation in melanoma, following BRAF and NRAS [35-37]. RAC1 mutation status is being considered a biomarker for resistance to RAF inhibitor therapy [35]. It has been shown that pre-existing mutations in MEK1 can confer resistance to RAF inhibitor therapy [38].

\subsection{Acquired Resistance}

Starting from the cell surface, several receptor tyrosine kinases (RTK) converge onto parallel pathways such as the MAPK and the PI3K-Akt pathway [39]. Upregulation of RTKs has been shown to directly activate the MAPK pathway via RAS activation [30]. Additionally, upregulation of specific RTKs such as the insulin like growth factor 1 receptor (IGFR1), platelet derived growth factor receptor $\beta$ (PDGFR $\beta$ ) can activate the PI3K-Akt pathway in a non-ERK dependent manner [40,41]. Epigenetic changes affecting epidermal growth factor receptor (EGFR) have been shown to also induce the PI3K-Akt pathway in melanoma resistant cells [42]. Dual activation of these pathways strongly contributes to drug resistance, as these pathways promote cell survival and proliferation. 
NRAS activating mutations are present in approximately 15-20\% of melanomas [43]. Q61 mutations in NRAS keeps it constitutively active in the 'RAS-GTP' state [44]. The activated mutant NRAS can activate the MAPK pathway via induction of dimerization of CRAF and BRAF [45].

Treatment with BRAF inhibitors will only inhibit the mutant monomer in BRAF mutant melanoma cells [46]. This plays an important role in the ability for these cells to maintain RAF dimerization which in turn keeps MAPK signaling active. A phenomenon known as the 'BRAF-inhibitor Paradox' describes the event in which the BRAF inhibitor blocks MAPK signaling in mutant cells but activates the MAPK pathway in non-mutant cells by allowing the drug-free RAF protein to be transactivated and dimerize [47]. RAF dimerization can be fulfilled through a variety of mechanisms including alternative BRAF splicing, amplification of BRAF, and expression of different RAF isoforms such as CRAF overexpression [48-51]. Resistance to RAF inhibition include activation of HGF and its receptor MET which lead to the reactivation of the MAPK and PI3K-AKT pathways [52]. Screening for the presence of RAF inhibitor resistance genes, found in a high percentage of patients can help improve treatment outcomes especially when used in conjunction with appropriate therapeutic combinations [53].

Secondary mutations in both MEK1 and MEK2 have also been linked to acquired resistance in melanoma cell lines [54]. The resistance to MEK inhibitors is attributed to mutations in MEK1/2 which lead to constitutive activation of MEK1/2 or a mutation in the drug binding site [55]. MAPK reactivation occurs via secondary mutations in MEK1 (Q56P or E203K) which help reactive the MAPK pathway downstream [56]. Additionally, BRAF amplification along with KRAS mutations can be contributing factors to MEK1/2 inhibitor resistance [57].

The RTK AXL has also been identified as a player in both intrinsic and acquired resistance. Patients relapsed of BRAF and MEK inhibitors overexpress AXL as an adaptive response [58]. Non-genomic mechanism of acquired resistance include high expression of transcriptomic alterations and intra-tumoral immunity which involves cytolytic T-cell inflammation [59].

Combination therapy using BRAF and MEK inhibitors has also shown signs of resistance. Proposed mechanisms of resistance include BRAF gene amplification, BRAF splice-variants and mutations in MEK2 [60]. Resistance to BRAF and MEK inhibitors exists by combining or augmenting the mechanisms related to single agent BRAF inhibitor resistance. The overexpressed BRAFV600E and MEK mutants interact via the regulatory interface of BRAFV600E, R662 [61]. Acquired resistance to combination targeted therapy has other factors contributing to it, including whether the patient had received inhibitor monotherapy prior to the combination therapy or is 'monotherapy naïve' [62].

Many recent advancements in the treatment of metastatic melanoma have been in the field of immunotherapy. There are proposed mechanisms of resistance to BRAF and MEK inhibitor therapy involving immune system molecules. Cancer cells, in general, aim to avoid immune recognition by downregulating surface receptors that participate in co-activation of $\mathrm{T}$ cells as well as upregulating negative feedback pathways, such as the immune checkpoint inhibitor receptors programmed cell death protein (PD-1) and T-lymphocyte associated protein-4 (CTLA-4). PD-1 and CTLA-4 are localized on the T-cells [63]. It is documented that after 2 weeks of treatment with BRAF and MEK inhibitors, melanoma cells have been able to downregulate melanoma differentiation antigens (MDA) surface expression, decrease $\mathrm{T}$ cell activity, and surface display of increase immune checkpoint inhibitory receptors [64,65]. This manipulation of key immune system regulators gives melanoma cells yet another way to bypass drug resistance. The rationale to combine an immune checkpoint inhibitor therapy with targeted therapy is that the treatment with a BRAF and MEK inhibitor renders the tumor microenvironment more immunoresponsive [66].

The sequence of treatment for a patient with targeted therapy and immune therapy is not well established. Starting a patient on a BRAF inhibitor or anti-PD1 inhibitor is effective regardless of the treatment order, but more randomized controlled trials are required to address and establish the superiority and sequencing of one therapy over the other [67,68]. Studies have also shown that the efficacy of immunotherapy is improved in previously untreated patients compared to patients who have single agent immunotherapy failure or failure to targeted therapy [69]. Despite showing 
exceptional clinical efficacy, treatment with immune checkpoint inhibitors has met some difficulties with respect to development of innate and acquired resistance [70,71]. Various clinical trials evaluating immune therapies such as Toll-like receptor 9 (TRL9) agonists, neoantigen vaccines and oncoloytic viruses alone or in combination with immune checkpoint inhibitors are underway. Combination of these therapies may help combat resistance to immune checkpoint inhibitors [72-77].

\section{Therapies}

Figure 1 summarizes the therapies in pre-clinical and clinical phases, described in this review to treat patients with metastatic melanoma.

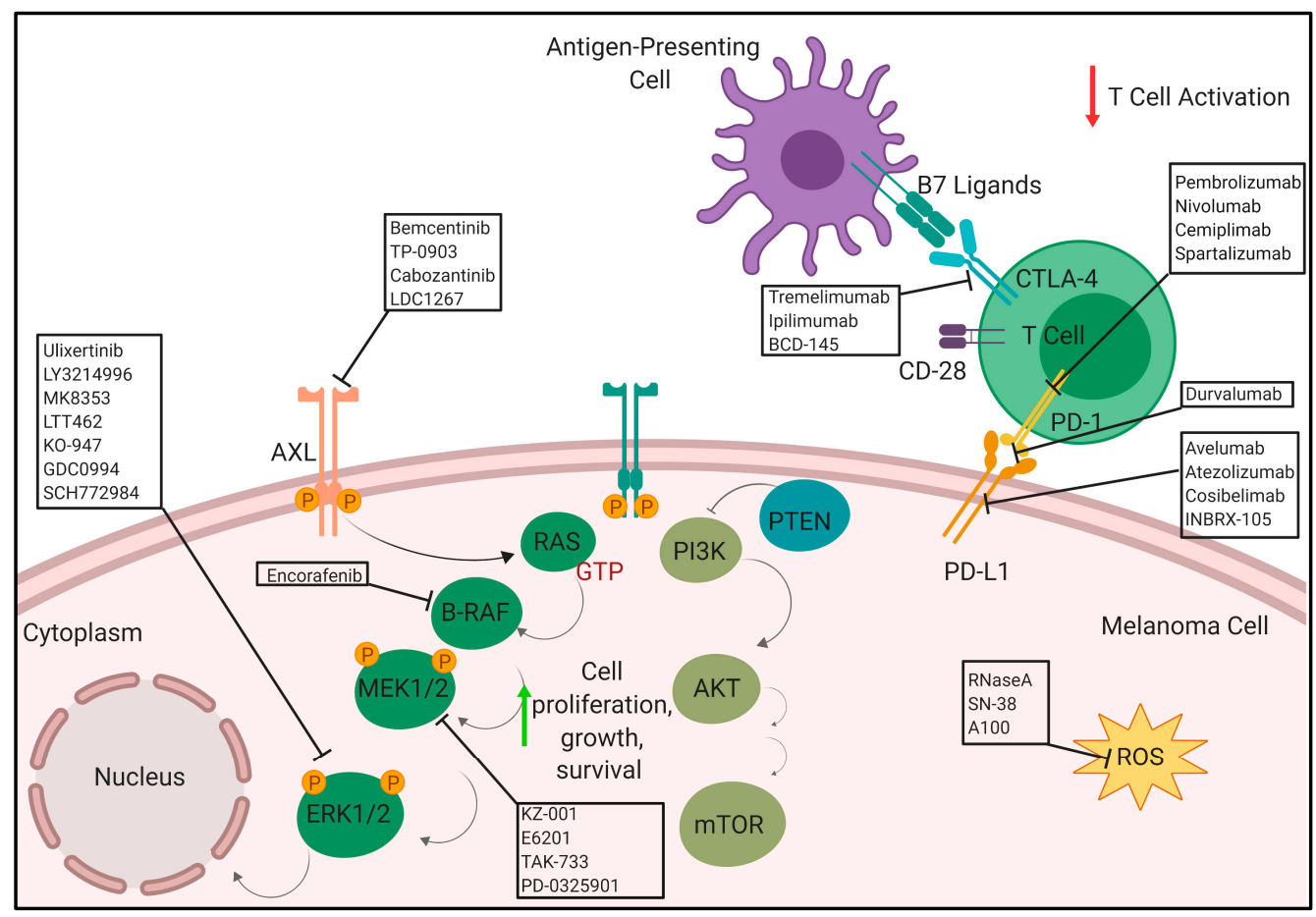

Figure 1. Novel therapies in pre-clinical and clinical phases (Anti PD-1/anti-PD-L1, anti CTLA-4, AXL inhibitors. BRAF inhibitors. ERK inhibitors and ROS activated prodrugs) to treat patients with metastatic melanoma (created with BioRender; www.biorender.com).

\section{Anti-PD-1/PD-L1}

The immunogenic nature of melanoma was utilized to develop several immunotherapeutic treatment strategies especially with regards to the programmed cell death (PD-1) receptor and its ligand, PD-L1. Antibodies targeting the PD-1 axis has shown significant promise in the clinic for treatment of metastatic melanoma either as a monotherapy or in combination with Ipilimumab. There are several ongoing clinical trials using anti-PD1 and anti-PD-L1 antibodies. Programmed cell death protein 1 (PD-1) is an inhibitory receptor expressed on the surface of the cancer cells that inhibits the immune system via suppressing the T-cell activity. Anti-PD-1 monoclonal antibodies block the PD-1 receptor which maintains T-cells in activated state to suppress the tumor growth [78]. There are several anti-PD-1/PD-L1 monoclonal antibodies including pembrolizumab (Keytruda ${ }^{\circledR}$ ), nivolumab (Opdivo ${ }^{\circledR}$ ), avelumab (Bavencio ${ }^{\circledR}$ ), durvalumab (Imfinzi ${ }^{\circledR}$ ), cemiplimab (Libtayo ${ }^{\circledR}$ ), atezolizumab (Tecentriq ${ }^{\circledR}$ ), cosibelimab and INBRX-105 in several stages of clinical trial in melanoma. Pembrolizumab, nivolumab and nivolumab in combination with ilpilimumab (anti-CTLA-4 inhibitor) have been approved by FDA for treatment of melanoma. 


\subsection{Pembrolizumab/Lambrolizumab/MK-3475/SCH 900475/Keytruda}

This is a humanized monoclonal antibody targeting the PD1 receptor in the lymphocytes. It was developed by Merck and approved for treatment of metastatic melanoma in 2017 [79].

\subsection{Nivolumab/ONO-4538/BMS-936558/MDX1106/Opdivo}

This is a human IgG4 anti-PD-1 monoclonal antibody. Nivolumab works as a checkpoint inhibitor that inhibits T-cell activation. [80]. It was developed by Medarex and Ono Pharmaceutical, and is marketed by Bristol-Myers Squibb (BMS) and Ono. Nivolumab was approved by the FDA for melanoma in 2014 [81,82].

\subsection{Avelumab/MSB0010718C/Bavencio}

This is a humanized monoclonal antibody developed by Merck and Pfizer that targets the PD-L1. It has been approved by FDA for treatment Merkel-cell carcinoma, an aggressive type of skin cancer [83]. It blocks the PD-1/PD-L1 receptor/ligand complex formation leading to suppression of CD8+ T cells action [84]. There is a current clinical trial (NCT01772004) investigating the safety, tolerability, pharmacokinetics and clinical activity of avelumab in melanoma [85].

\subsection{Durvalumab/MEDI4736/Imfinzi}

This is monoclonal antibody that blocks the interaction of PD-L1 with the PD-1 and CD80 (B7.1) molecules developed by Medimmune/AstraZeneca [86,87]. A phase I clinical trial (NCT02586987) is ongoing evaluating the safety and efficacy of selumetinib (AZD6244 Hyd-sulfate) in combination with durvalumab (MEDI4736) along with tremelimumab in patients with advanced solid tumours, including melanoma [88].

\subsection{Atezolizumab/MPDL3280A/Tecentriq}

This is a fully humanized engineered monoclonal antibody of IgG1 isotype against PD-L1 developed by Genentech [89,90]. There is an active ongoing phase II trial (NCT02303951) which includes the combination of vemurafenib, cobimetinib and atezolizumab in stage III/IV advanced melanoma patients [91]. Another phase III study (NCT02908672) compares the efficacy of atezolizumab in combination with cobimetinib and vemurafenib versus placebo control plus cobimetinib and vemurafenib in unresectable and advanced melanoma patients with BRAFV600 mutation [92].

\subsection{Spartalizumab/PDR001}

Spartalizumab (PDR001) is a humanized monoclonal antibody against the negative immuno-regulatory human cell surface receptor programmed death-1 (PD-1, PCD-1) was developed by Novartis. This suppresses T-cell activation as it binds to PD-1 on activated T-cells and inhibits the interaction with its ligands, (PD-L1, PD-1L1) and (PD-L2, PD-1L2) [93]. A phase I/lb (NCT03891953) study evaluating the efficacy of spartalizumab in combination with DKY709 (immunomodulatory agent) in patients with advances solid tumors including melanoma is ongoing [94]. A phase II PLATforM (NCT03484923) study evaluating the efficacy and safety of spartalizumab in combinations with LAG525 (monoclonal antibody targeting LAG-3), capmatinib (MET inhibitor), canakinumab (monoclonal antibody targeting IL-1 $\beta$ ) and ribociclib (CDK4/6 inhibitor) is ongoing in previously treated unresectable or metastatic melanoma [95]. A phase III COMBI-i study (NCT02967692) comparing the combination of spartalizumab, dabrafenib and trametinib versus dabrafenib and trametinib in previously untreated patients with unresectable or metastatic BRAFV600 mutant melanoma is initiated [96]. 


\section{Anti-CTLA-4}

In addition to PD-1, another immune checkpoint inhibitor, cytotoxic T-lymphocyte antigen 4 (CTLA-4), is important in melanoma. It is found on the surface of regulatory T cells (Treg) and activated T cells [97]. CTLA-4 competes with CD28, another receptor expressed on the surface of $T$ cells, to interact with its two ligands CD80 and CD86, collectively known as the B7 ligands. When CTLA-4 binds with the B7 ligands, commonly found on antigen presenting cells (APC), it results in an immunosuppressive response, which is the inhibition of $\mathrm{T}$ cell activation via transendocytosis of CD80 and CD86 from their surfaces $[98,99]$. Typically, $\mathrm{T}$ cell activation requires co-stimulation from the CD28-B7 ligand interaction and the TCR-MHC interaction [100]. However, CTLA-4 has a stronger affinity for the B7 ligands, making it a good immune checkpoint inhibitor that keeps the immune response from turning into an autoimmune one [97]. CTLA-4 is expressed on tumor cells, infiltrating Tregs, and exhausted, activated $\mathrm{T}$ cells [101]. Tumor cells, therefore, take advantage of this natural immunosuppressive system in order to prevent an immune response against them. This provides a therapeutic approach which involves anti-CTLA-4 therapy. There are currently three main anti-CTLA-4 antibodies under preclinical and clinical trials for the treatment of melanoma: Tremelimumab, Ipilimumab (Yervoy), and BCD-145.

\subsection{Tremelimumab/Ticilimumab/CP 675.206}

This human monoclonal antibody against CTLA-4 was developed by AstraZeneca [102]. A phase I active, clinical trial (NCT02141542) is -evaluating tremelimumab in combination with MEDI3617 (human anti-angiopoietin 2 monoclonal antibody) for unresectable Stage III/IV melanoma patients [103]. Another phase I active, clinical trial (NCT01103635) is examining tremelimumab in combination with CP-870,893 CD40 agonist monoclonal antibody) for metastatic melanoma [104].

\subsection{Ipilimumab/MDX010/BMS-734016}

This human monoclonal antibody against CTLA-4 was developed by YERVOY Medarex/BMS. It was approved by the FDA in 2011 for the treatment of unresectable or metastatic melanoma [105]. There are current, active clinical trials devoted to assess the efficacy of ipilimumab in combination with other immunotherapies or targeted therapies for metastatic melanoma. A phase I clinical trial (NCT02115243) that assessed ipilimumab as a neoadjuvant followed by melphalan (chemotherapeutic) via isolated limb perfusion in patients with unresectable in-transit extremity melanoma is completed [106]. A phase Ib clinical trial (NCT02117362) evaluating ipilimumab in combination with GR-MD-02 (galnectin inhibitor) in metastatic melanoma patients has been completed [107]. A phase II clinical trial (NCT03153085) examining ipilimumab in combination with TBI-1401(HF10) in Japanese patients with Stage IIIb, IIIc, IV unresectable or metastatic malignant melanoma has been completed [108]. A phase II clinical trial (NCT01970527) looking at SBRT followed by Ipilimumab in patients with stage IV and recurrent melanoma has been completed [109].

\section{3. $B C D-145$}

This human monoclonal antibody against CTLA-4 is developed by BIOCAD [110]. A completed phase I clinical trial (NCT03472027) studied the efficacy of BCD-145 in unresectable/metastatic melanoma [111]. The combination of anti-PD-1/PD-L1 and anti-CTLA-4 are also being tested in the clinic for stage III/IV melanoma patients. A phase I clinical trial (NCT02935790) evaluating ipilimumab and nivolumab in combination with ACY-241 (selective HDAC inhibitor) is completed [112]. Current clinical trials, outcomes and adverse events investigating the efficacy of anti-CTLA-4, anti-PD-1/PD-L1 therapies and their combinations used to treat metastatic melanoma patients are listed in Table 1 [113-160]. 
Table 1. Summary of clinical trials, outcomes and adverse events associated with anti-PD-1/PD-L1, anti-CTLA-4 and their combination in metastatic melanoma patients.

\begin{tabular}{|c|c|c|c|c|c|}
\hline Treatment & Status & Sponsor & Phase and NCT & Clinical Outcomes & Adverse Events \\
\hline \multicolumn{6}{|c|}{ Anti-PD-1/PD-L1 } \\
\hline $\begin{array}{l}\text { Pembrolizumab in Japenese } \\
\text { patients with advanced } \\
\text { melanoma (KEYNOTE-041) } \\
\text { [113] }\end{array}$ & Completed & $\begin{array}{l}\text { Merck Sharp \& } \\
\text { Dohme Corp }\end{array}$ & Ib, NCT02180061 & $\begin{array}{l}\text { Pembrolizumab has promising anti-tumor activity and an } \\
\text { acceptable safety profile in patients with cutaneous melanoma ( } n= \\
\text { 29). As per central review, the median overall survival (OS) and } \\
\text { median duration of response was not reached. The } 1 \text { year OS was } \\
82.7 \% \text {. The median profession-free survival (PFS) and } 6 \text { months } \\
\text { PFS was } 4.2 \text { months ( } 95 \% \text { CI: } 2.8-7 \text { months) and } 41.4 \% \text { respectively. } \\
\text { The overall response, complete response (CR) and partial response } \\
\text { (PR) were } 24.1 \% \text { (95\% CI: } 10.3-43.55), 6.9 \% \text { (95\% CI: } 0.8-22.8 \% \text { ) and } \\
17.2 \% \text { (95\% CI: } 5.8-35.8 \% \text { ) respectively. }\end{array}$ & $\begin{array}{l}\text { Pruritus, anemia, } \\
\text { maculopapular rash, malaise, } \\
\text { and hypothyroidism }\end{array}$ \\
\hline $\begin{array}{l}\text { Study of pembrolizumab } \\
\text { (MK-3475) versus } \\
\text { chemotherapy in patients } \\
\text { with advanced melanoma } \\
\text { KEYNOTE-002) [114] }\end{array}$ & Completed & $\begin{array}{l}\text { Merck Sharp \& } \\
\text { Dohme Corp. }\end{array}$ & II, NCT01704287 & $\begin{array}{l}\text { The progression-free survival was improved in patients assigned to } \\
\text { pembrolizumab } 2 \mathrm{mg} / \mathrm{kg} \text { (HR } 0.57,95 \% \mathrm{CI} 0.45-0.73 ; p<0.0001) \\
\text { and those assigned to pembrolizumab } 10 \mathrm{mg} / \mathrm{kg}(0.50,0.39-0.64 ; p \\
<0.0001 \text { ) compared with those assigned to chemotherapy. 6-month } \\
\text { progression-free survival was } 34 \%(95 \% \mathrm{CI} 27-41) \text { in the } \\
\text { pembrolizumab } 2 \mathrm{mg} / \mathrm{kg} \text { group, } 38 \%(31-45) \text { in the } 10 \mathrm{mg} / \mathrm{kg} \text { group, } \\
\text { and } 16 \%(10-22) \text { in the chemotherapy group. }\end{array}$ & $\begin{array}{l}\text { Fatigue, generalised oedema, } \\
\text { myalgia, hypopituitarism, } \\
\text { colitis, diarrhoea, anemia } \\
\text { decreased appetite, } \\
\text { hyponatremia, pneumonitis, } \\
\text { neutropenia and leucopenia. }\end{array}$ \\
\hline $\begin{array}{l}\text { Pembrolizumab versus } \\
\text { ipilimumab in advanced } \\
\text { melanoma (KEYNOTE-006) } \\
\text { [115] }\end{array}$ & Completed & $\begin{array}{l}\text { Merck Sharp \& } \\
\text { Dohme Corp. }\end{array}$ & III, NCT01866319 & $\begin{array}{l}\text { Pemrolizumab showed superiority over ipilimumab at } 5 \text { year } \\
\text { follow up time. } 834 \text { patients were stratified into three groups: (i) } \\
\text { Pembrolizumab ( } 10 \mathrm{mg} / \mathrm{kg} \text { i.v. every } 2 \text { weeks), (ii) Pembrolizumab } \\
\text { ( } 10 \mathrm{mg} / \mathrm{kg} \text { i.v. every } 3 \text { weeks) and Ipilimumab ( } \mathrm{mg} / \mathrm{kg} \text { i.v. every } 3 \\
\text { weeks). The median follow up was } 57.5 \text { months (IQR: } 56.7-59.2 \\
\text { months). Combined Pembrolizumab groups: The median OS and } \\
\text { PFS were } 32.7 \text { months ( } 95 \% \text { CI: } 24.5-41.6 \text { months) and } 8.4 \text { months } \\
\text { (95\% CI: } 6.6-11.3 \text { months) respectively. The ORR was } 42 \% \text { ( } 95 \% \text { CI: } \\
38.1-46.5 \%) \text {. } \\
\text { Ipilimumab groups: The median OS and PFS were } 15.9 \text { months } \\
\text { (95\% CI:13.3-22 months; HR 0.73; } 95 \% \text { CI for HR- } 0.61-0.88 ; p= \\
0.00049) \text { and } 3.4 \text { months ( } 95 \% \text { CI: } 2.9-4.2 \text { months; HR } 0.57 ; 95 \% \text { CI } \\
\text { for HR: } 0.48-0.67 ; p<0.0001) \text { respectively. The ORR was } 17 \%(95 \% \\
\text { CI: } 12.4-21.4 \%) \text {. }\end{array}$ & $\begin{array}{l}\text { Fatigue, colitis, diarrhea, } \\
\text { asthenia, arthralgia, rash, } \\
\text { pruritus, vitiligo. }\end{array}$ \\
\hline $\begin{array}{l}\text { Durvalumab in combination } \\
\quad \text { with Dabrafenib and } \\
\text { Trametinib in patients with } \\
\text { advanced melanoma [116] }\end{array}$ & Completed & MedImmune LLC & I. NCT02027961 & $\begin{array}{c}\text { Durvalumab in combination with dabrafeib and trametinib had } \\
\text { manageable safety profile. No maximum tolerated dose was } \\
\text { identified }(n=50) \text { and durvalumab } 10 \mathrm{mg} / \mathrm{kg} \text { was selected for } \\
\text { further studies. }\end{array}$ & $\begin{array}{l}\text { Pyrexia, fatigue, diarrhea, rash, } \\
\text { vomiting and other drug } \\
\text { related toxicities }\end{array}$ \\
\hline
\end{tabular}


Table 1. Cont.

\begin{tabular}{|c|c|c|c|c|c|}
\hline Treatment & Status & Sponsor & Phase and NCT & Clinical Outcomes & Adverse Events \\
\hline $\begin{array}{l}\text { Nivolumab in metastatic } \\
\text { melanoma patients [117] }\end{array}$ & $\begin{array}{l}\text { Active, } \\
\text { not } \\
\text { recruiting }\end{array}$ & $\begin{array}{c}\text { BMS in } \\
\text { collaboration with } \\
\text { Ono } \\
\text { Pharmaceutical Co. } \\
\text { Ltd. }\end{array}$ & I, NCT00730639 & $\begin{array}{c}\text { Treatment with nivolumab is associated with long-term survival in } \\
\text { patients with melanoma ( } n=72 \text { ). The median duration to response } \\
\text { and objective response rate (ORR) was } 22.9 \text { months ( } 95 \% \text { CI: } \\
\text { 19.7-31.8 months) and } 31.8 \% \text { respectively. The median, estimated } 3 \\
\text { years and } 5 \text { year overall survival rates were } 20.3 \text { months }(95 \% \text { CI: } \\
12.5-37.9 \text { months), } 42.3 \% \text { ( } 95 \% \text { CI: } 32.7-51.6 \%) \text { and } 34.2 \% \text { ( } 95 \% \text { CI: } \\
25.2-43.4 \%) \text { respectively. Patients who had an ORR had } \\
\text { significantly higher mean baseline absolute lymphocytes count } \\
\text { (1480 cells/uL) as compared to patients without response (1300 } \\
\text { cells/uL; } p=0.4) \text {. }\end{array}$ & $\begin{array}{l}\text { Anemia, hypothryoididm, } \\
\text { gastrointestinal disorder, } \\
\text { general disorder, muscular } \\
\text { disorder, nasopharyngitis, } \\
\text { decreased apatite, nervous and } \\
\text { respiratory problems, vascular } \\
\text { and skin disorder }\end{array}$ \\
\hline $\begin{array}{l}\text { Atezolizumab in } \\
\text { combination with } \\
\text { vemurafenib alone or in } \\
\text { combination with } \\
\text { cobimetinib [118] }\end{array}$ & $\begin{array}{c}\text { Active, } \\
\text { not } \\
\text { recruiting }\end{array}$ & Genentech, Inc. & Ib, NCT01656642 & $\begin{array}{l}\text { The triple combination was safe, tolerable and had a promising } \\
\text { anti-tumor activity. Atezolimumab + Vemurafenib ( } n=17) \text { : The } \\
\text { best objective response rate and complete response rate was } 76.5 \% \\
\text { (95\% CI: } 50.1-93.2 \% \text { ) and } 17.6 \% \text { respectively. All the patients } \\
\text { demonstrated a reduction in the sum of the longest diameter of the } \\
\text { target lesion. The median duration of response, PFS and OS was } \\
10.6 \text { months ( } 95 \% \text { CI: } 9.1-37.6 \text { months), } 10.9 \text { months ( } 95 \% \text { CI: } 5.7-22 \\
\text { months) and } 46.2 \text { months ( } 95 \% \text { CI: } 24.1 \text {-not reached) respectively. } \\
\text { Estimated OS rates for } 1 \text { year were } 82 \% \text {. } \\
\text { Atezolimumab + Vemurafenib + Cobimetinib ( } n=39) \text { : The best } \\
\text { objective response rate and complete response rate was } 71.8 \% \text { ( } 95 \% \\
\text { CI: } 55.1-85 \% \text { and } 20.5 \% \text { respectively. All the patients } \\
\text { demonstrated a reduction in the sum of the longest diameter of the } \\
\text { target lesion. The median duration of response and PFS was } 17.4 \\
\text { months ( } 95 \% \text { CI: } 10.6-25.3 \text { months), } 12.9 \text { months ( } 95 \% \text { CI: } 8.7-21.4 \\
\text { months) respectively. The median OS was not reached. Estimated } \\
\text { OS rates for } 1 \text { year were } 83 \% \text {. Treatment with vemurafenib alone or } \\
\text { in combination with cobimetinib exhibited an increase in the } \\
\text { proliferating CD4+ T-helper cells and addition of atezolizumab led } \\
\text { to further escalation in these cells. CD } 8+\text { cytotoxic T cells were } \\
\text { augmented on addition of atezolizumab. }\end{array}$ & $\begin{array}{l}\text { Increase in AST, ALT and blood } \\
\text { bilirubin, hyponatremia, blood } \\
\text { alkaline phosphatase, rash, } \\
\text { diarrhea, vomiting. }\end{array}$ \\
\hline
\end{tabular}


Table 1. Cont.

\begin{tabular}{|c|c|c|c|c|c|}
\hline Treatment & Status & Sponsor & Phase and NCT & Clinical Outcomes & Adverse Events \\
\hline $\begin{array}{c}\text { Tremelimumab in patients } \\
\text { with advanced refractory } \\
\text { and/or relapsed melanoma } \\
\text { [119] }\end{array}$ & Completed & AstraZeneca & II, NCT00254579 & $\begin{array}{l}\text { Tremelimumab showed a durable response in these patients }(n= \\
\text { 241). The ORR was } 6.6 \% \text { and the duration of response was } 8.9-29.8 \\
\text { months. The median OS and clinical benefit rate was } 10.1 \text { months } \\
\text { ( } 95 \% \text { CI: } 7.9-11.7 \text { months) and } 21 \% \text { respectively.. The survival rate } \\
\text { at } 1 \text { and } 2 \text { years was } 40 \% \text { ( } 95 \% \text { CI: } 34-46 \%) \text { and } 22 \% \text { ( } 95 \% \text { CI: } \\
17-27 \% \text { ) respectively. Median PFS and } 6 \text { months PFS was } 2.8 \\
\text { months ( } 95 \% \text { CI: } 2.7-2.8 \text { months) and } 15 \% \text { respectively. As per } \\
\text { Response Evaluation Criteria in Solid Tumors (RECIST) criteria, } \\
3.3 \% \text { of the patients achieved response at the target lesion. }\end{array}$ & $\begin{array}{l}\text { Diarrhea, pruritus, rash, nausea, } \\
\text { fatigue, vomiting and colitis. }\end{array}$ \\
\hline $\begin{array}{l}\text { Ipilimumab alone or in } \\
\text { combination with } \\
\text { dacarbazine, paclitaxel and } \\
\text { carboplatin [120] }\end{array}$ & Completed & $\begin{array}{c}\text { BMS in } \\
\text { collaboration with } \\
\text { Medarex }\end{array}$ & I, NCT00796991 & 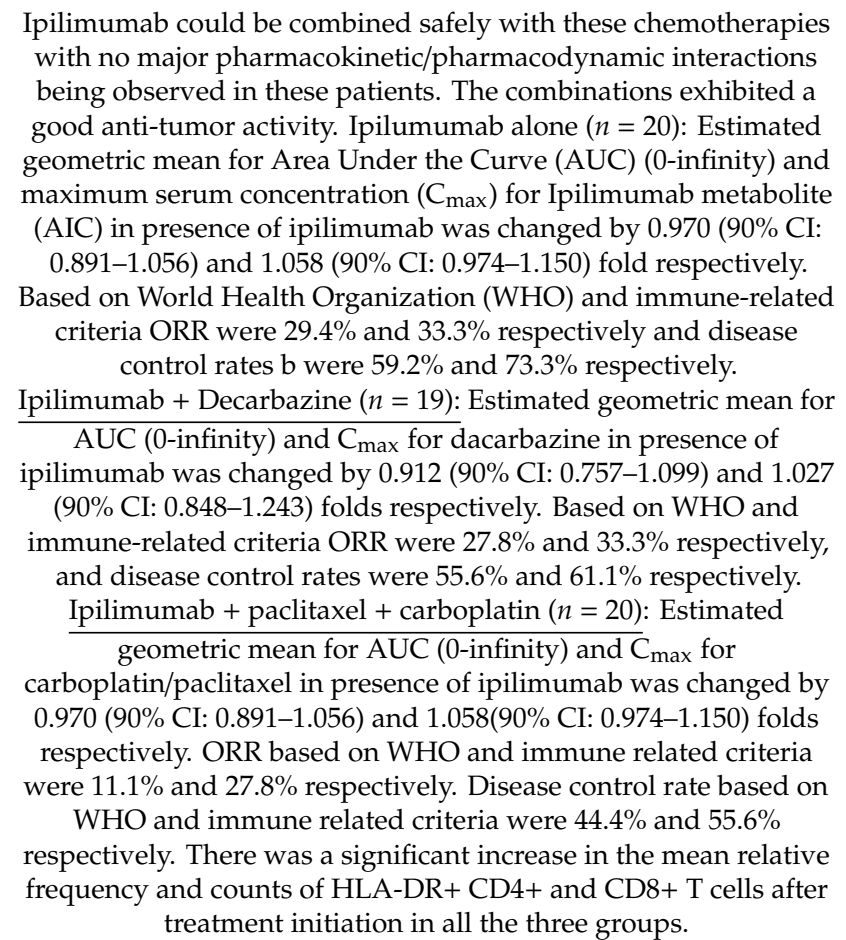 & $\begin{array}{l}\text { Rash, fatigue, diarrhea, } \\
\text { pruritus, nausea, increase in } \\
\text { ALT and AST, decreased } \\
\text { neutrophil count. }\end{array}$ \\
\hline
\end{tabular}


Table 1. Cont.

\begin{tabular}{|c|c|c|c|c|c|}
\hline Treatment & Status & Sponsor & Phase and NCT & Clinical Outcomes & Adverse Events \\
\hline $\begin{array}{l}\text { Ipilimumab in combination } \\
\text { with imatinib mesylate in } \\
\text { patients with advanced } \\
\text { malignancies [121] }\end{array}$ & Completed & $\begin{array}{c}\text { M.D. Anderson } \\
\text { Cancer Center in } \\
\text { collaboration with } \\
\text { NCI }\end{array}$ & I, NCT01738139 & $\begin{array}{l}\text { The combination was well tolerated and safe and the MTD and } \\
\text { recommended phase } 2 \text { dose for intravenous ipilimumab was } 3 \\
\mathrm{mg} / \mathrm{kg} \text { every } 3 \text { weeks and imatinib mesylate at } 400 \mathrm{mg} \text { orally twice } \\
\text { daily. Twenty six patients were enrolled in dose escalation cohort } \\
\text { Expression of ICOS and OX } 40 \text { was increased on the CD4 + T cells } \\
\text { upon ipilimumab treatment. }\end{array}$ & $\begin{array}{l}\text { Fatigue, nausea, vomiting, } \\
\text { edema, anemia, diarrhea, rash, } \\
\text { fever. }\end{array}$ \\
\hline $\begin{array}{l}\text { Ipilimumab and high dose } \\
\text { IFN- } \alpha 2 B \text { as a neoadjuvant } \\
\text { combination for } \\
\text { locally/regionally } \\
\text { advanced/recurrent } \\
\text { melanoma [122] }\end{array}$ & Completed & $\begin{array}{l}\text { Diwakar Davar, } \\
\text { University of } \\
\text { Pittsburgh }\end{array}$ & I, NCT01608594 & $\begin{array}{l}\text { The combination was well tolerated and exhibited promising } \\
\text { durable clinical response rates. } 30 \text { patients were enrolled. The } \\
\text { median follow-up was } 32 \text { months and the pathologic complete } \\
\text { response rate was } 32 \%(95 \% \text { CI: } 18-51 \%) \text {. The radiologic response } \\
\text { rate was } 36 \% \text { ( } 95 \% \text { CI: } 21-54 \% \text { ). The median PFS was not reached } \\
\text { and the probability of PFS at } 12 \text { and } 6 \text { months was } 0.79 \text { ( } 95 \% \text { CI: } \\
0.65-0.95) \text { and } 0.86 \text { ( } 95 \% \text { CI: } 0.74-1 \text { ) respectively. The probability of } \\
\text { OS at } 2 \text { years and } 1 \text { year was } 0.89 \text { (95\% CI: } 0.79-1) \text { and } 0.93 \text { ( } 95 \% \text { Ci: } \\
0.84-1 \text { ) respectively. The peripheral blood mononuclear cell was } \\
\text { significantly lower at } 12 \text { weeks ( } p=0.025) \text {. The tumor-infiltrating } \\
\text { lymphocyte (TIL) was significantly higher in primary melanoma } \\
\text { tumors for patients with pathologic complete response ( } p=0.033) \text {. } \\
\text { There was an increase in the number of tumor associated clones } \\
\text { following the neoadjuvant treatment and it showed a strong } \\
\text { correlation with TIL fraction }(\rho=0.7299 ; p=0.0003) \text { and TIL clone } \\
\text { diversity ( } \rho=0.882 ; p=2.7-7) \text {. The increase in the tumor T-cell } \\
\text { clonality in the primary tumor and a further increase in the } \\
\text { clonality after neoadjuvant therapy was statistically significant } \\
\text { with relapse-free survival. }(p=0.048 \text { for tumor clonality and } p= \\
0.018 \text { for post treatment metastatic clonality). }\end{array}$ & $\begin{array}{c}\text { Fever, fatigue, creatinine } \\
\text { increase, skin, GI, hepatic, } \\
\text { endocrine and hematologic } \\
\text { disorders. }\end{array}$ \\
\hline $\begin{array}{l}\text { Ipilimumab in combination } \\
\text { with PEG-Intrerferon (IFN) } \\
\alpha 2 B \text { on for Stage IIb/c/IV } \\
\text { unresected melanoma [123] }\end{array}$ & Completed & $\begin{array}{l}\text { H. Lee Moffitt } \\
\text { Cancer Center and } \\
\text { Research Institute } \\
\text { in collaboration } \\
\text { with Merck Sharp } \\
\text { \& Dohme Corp. }\end{array}$ & Ib, NCT01496807 & $\begin{array}{l}\text { The maximum tolerated dose established was } 3 \mathrm{mg} / \mathrm{kg} \text { of } \\
\text { Ipilimumab and } 2 \mathrm{ug} / \mathrm{kg} / \text { week of peginterferon alfa- } 2 \mathrm{~b} \text { was } \\
\text { efficacious and well tolerated. } 30 \text { patients were enrolled. } \\
\text { Immune related response criteria: } 3.33 \% \text { and } 36.67 \% \text { of the subjects } \\
\text { achieved a CR and PR respectively. The overall response rate was } \\
40 \% \text {. The median follow up time was } 35.8 \text { months (Range: } \\
\text { 19.7-50.2 months). The median PFS was } 5.9 \text { months and median } \\
\text { OS was not reached. At } 40.3 \text { months, } 16.7 \% \text { of the patients had a } \\
\text { prolonged PFS without any need for further therapy. } 85.6 \% \text { of the } \\
\text { subjects had an objective response. Here was a significant } \\
\text { correlation between autoimmune vitiligo and objective response ( } p \\
=0.009 \text { ). }\end{array}$ & $\begin{array}{l}\text { Anemia, dry eye, GI disorders, } \\
\text { chills, fatigue, fever, increase in } \\
\text { blood enzymes, anorexia, } \\
\text { muskoskeletal and connective } \\
\text { tissue disorders, nervous } \\
\text { system disorders. Cough, } \\
\text { dyspnea, depression, skin and } \\
\text { subcutaneous tissue disorders }\end{array}$ \\
\hline
\end{tabular}


Table 1. Cont.

\begin{tabular}{|c|c|c|c|c|c|}
\hline Treatment & Status & Sponsor & Phase and NCT & Clinical Outcomes & Adverse Events \\
\hline $\begin{array}{l}\text { Intratumoral injection of } \\
\text { Ipilimumab and IL-2 for } \\
\text { unresectable stage III/IV } \\
\text { melanoma }[124,125]\end{array}$ & Completed & University of Utah & I, NCT01672450 & 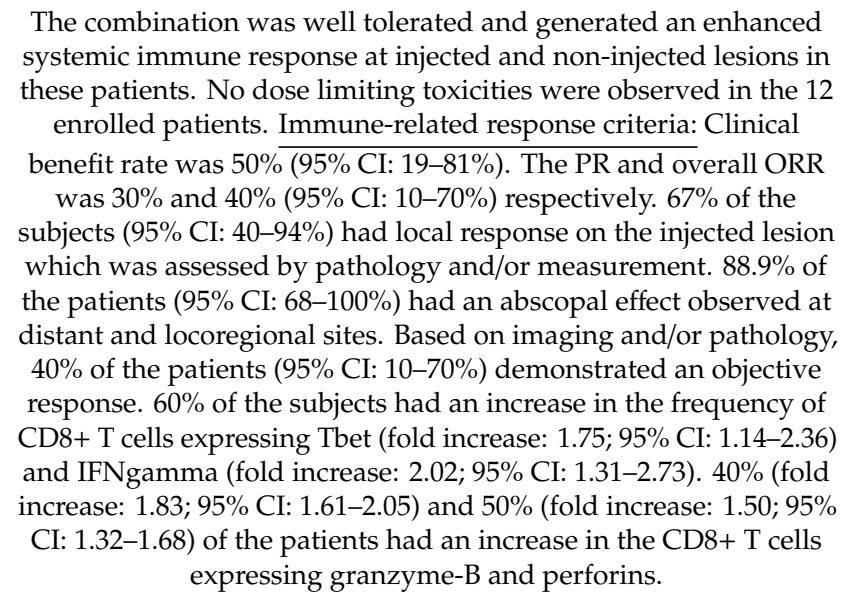 & $\begin{array}{l}\text { Chills, fatigue, flu like } \\
\text { symptoms, pain and ulceration } \\
\text { at site of injection, rash, soft } \\
\text { tissue infection. No grade } 4 / 5 \\
\text { toxicities were observed. }\end{array}$ \\
\hline $\begin{array}{c}\text { Ipilimumab in combination } \\
\text { with Stereotactic } \\
\text { Radiosurgery (SRS) or } \\
\text { Whole Brain Radiation } \\
\text { Therapy (WBRT) [126] }\end{array}$ & Completed & $\begin{array}{c}\text { Sidney Kimmel } \\
\text { Cancer Center at } \\
\text { Thomas Jefferson } \\
\text { University in } \\
\text { collaboration with } \\
\text { BMS }\end{array}$ & I, NCT01703507 & $\begin{array}{l}\text { The combination of ipilimumab ( } 3 \mathrm{mg} / \mathrm{kg} ; n=7 \text { or } 10 \mathrm{mg} / \mathrm{kg} ; n=9) \\
\text { and SRS was safe without any dose limiting toxicities. } \\
\text { Arm A (WBTR; } n=5 \text { ): The median follow-up time was } 8 \text { months } \\
\text { (Range: } 3.5-24.1 \text { months). Median time to intracranial progression, } \\
\text { PFS and OS were } 2.53 \text { months (Range } 0.3-18 \text { months), } 2.5 \text { months } \\
\text { and } 8 \text { months respectively. Arm B (SRS; } n=11 \text { ): the median } \\
\text { follow-up time was } 10.5 \text { months (Range: } 1.8-36.8 \text { months). Median } \\
\text { time to intracranial progression and PFS was } 2.45 \text { months (Range: } \\
\text { 1-37 months) } 2.1 \text { months respectively. The median OS was not } \\
\text { reached. Immune-related PR was } 7 \% \text {. }\end{array}$ & $\begin{array}{l}\text { Neurotoxic effects, headache, } \\
\text { GI toxicity, vomiting, } \\
\text { subclinical intracranial } \\
\text { hemorrhage, increase in ALT, } \\
\text { dizziness, tinnitus. No grade } \\
\text { 4/5 and radionecrosis were } \\
\text { observed. }\end{array}$ \\
\hline
\end{tabular}


Table 1. Cont

\begin{tabular}{|c|c|c|c|c|c|}
\hline Treatment & Status & Sponsor & Phase and NCT & Clinical Outcomes & Adverse Events \\
\hline $\begin{array}{l}\text { Ipilimumab in subjects with } \\
\text { previously treated } \\
\text { unresectable stage III/IV } \\
\text { melanoma [127] }\end{array}$ & Completed & $\begin{array}{c}\text { BMS in } \\
\text { collaboration with } \\
\text { Medarex }\end{array}$ & II NCT00289640 & 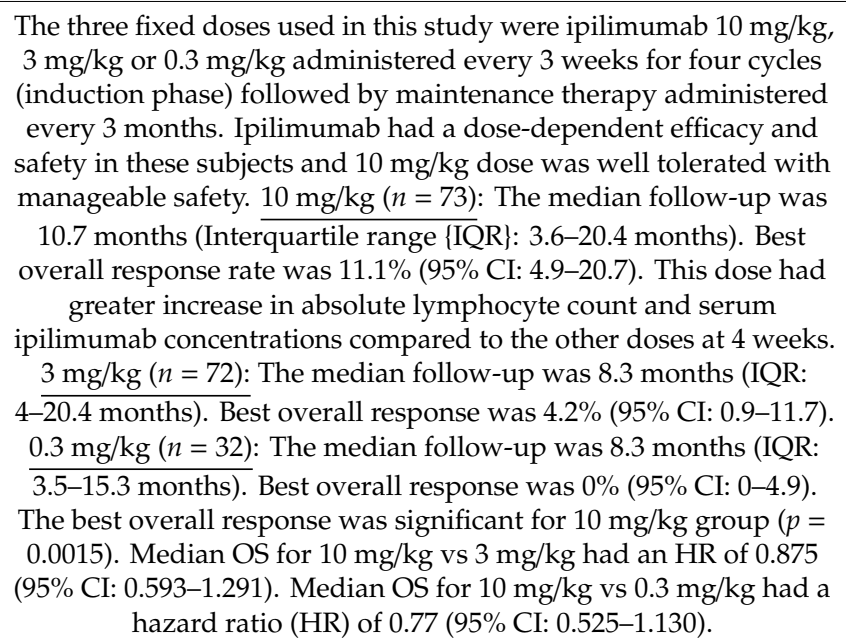 & $\begin{array}{l}\text { Immune-related grade 3-4 } \\
\text { events were GI related, skin } \\
\text { related, nausea, vomiting, } \\
\text { pruritus, rash, endocrine. Some } \\
\text { immune related grade } 5 \\
\text { adverse events were observed. }\end{array}$ \\
\hline $\begin{array}{l}\text { Ipilimumab in combination } \\
\text { with Fotemustine for } \\
\text { unresectable locally } \\
\text { advanced or metastatic } \\
\text { malignant melanoma with } \\
\text { or without brain metastasis } \\
\text { (NIMIT-M1) [128] }\end{array}$ & Completed & $\begin{array}{l}\text { Italian Network } \\
\text { for Tumor } \\
\text { Biotherapy in } \\
\text { collaboration with } \\
\text { BMS }\end{array}$ & II, NCT01654692 & 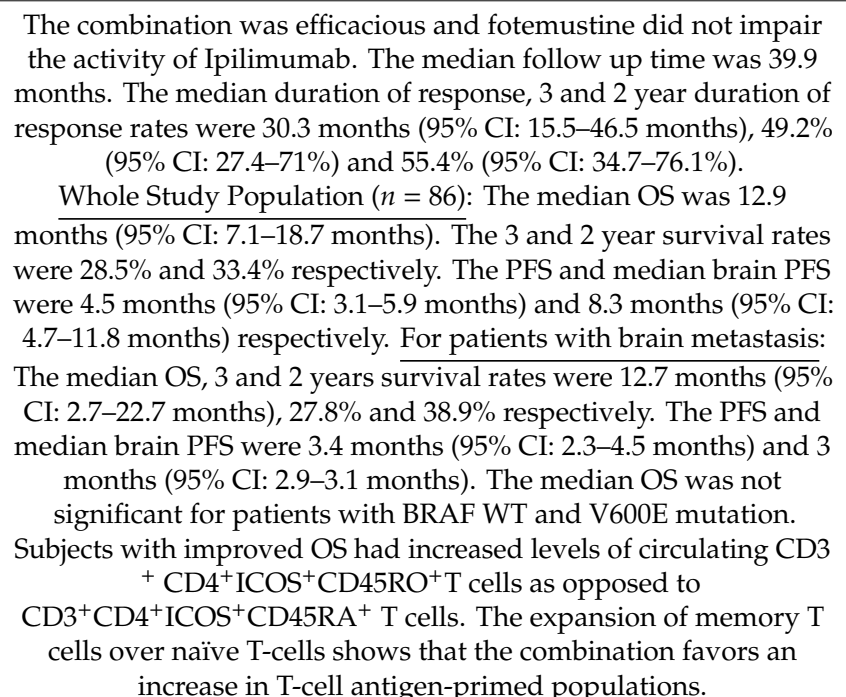 & Rash, pruritus \\
\hline
\end{tabular}


Table 1. Cont.

\begin{tabular}{|c|c|c|c|c|c|}
\hline Treatment & Status & Sponsor & Phase and NCT & Clinical Outcomes & Adverse Events \\
\hline $\begin{array}{l}\text { Ipilimumab in advanced } \\
\text { melanoma patients with } \\
\text { preexisting humoral } \\
\text { response to NY-ESO-1 [129] }\end{array}$ & Completed & $\begin{array}{c}\text { National Center } \\
\text { for Tumor } \\
\text { Diseases, } \\
\text { Heidelberg in } \\
\text { collaboration with } \\
\text { University } \\
\text { Hospital } \\
\text { Heidelberg }\end{array}$ & II, NCT01216696 & $\begin{array}{l}\text { Ipilimumab demonstrated a higher clinical efficacy in patients with } \\
\text { NY-ESO-1, maybe used as a surrogate for preexisting immune } \\
\text { response to tumor antigens. } 25 \text { patients were enrolled in the study. } \\
\text { The median duration of treatment was } 64 \text { days (Range: } 1-352 \text { days). } \\
\text { Immune-related response criteria: the disease control rate was } 52 \% \\
\text { (90\% CI: } 34.1-69.5 \%) \text {. } 36 \% \text { of the subjects had a PR. The PFS was } \\
7.8 \text { months ( } 95 \% \text { CI: } 2.6-n \text { moths). No significant association was } \\
\text { observed between best response and the amount of } \\
\text { NY-ESO-1-specific T-cells. RECIST criteria: } 24 \% \text { of the subjects had } \\
\text { a PR. The PFS was } 2.9 \text { months (95\%CI: } 2.5-8.1 \text { months). The } \\
\text { median OS was } 22.7 \text { months (95\%CI: } 9.5-n \text { months). The } 1 \text { year } \\
\text { survival rate was } 66.8 \% \text { ( } 95 \% C I \text { : } 0.44-0.82) \text {. The best overall } \\
\text { response (BOR) had a statistically significant association with the } \\
\text { OS ( } p=0.0031) \text {. For a small subset of patients there was a } \\
\text { statistically significant association between PFS and } \\
\text { NY-ESO-1-specific CD3+ T-cells (HR: } 1.039 ; p=0.0478 \text { ). }\end{array}$ & $\begin{array}{l}\text { Endocrine, GR, hepatobiliary, } \\
\text { musculoskeletal and connective } \\
\text { tissue disorders, headache, skin } \\
\text { and subcutaneous tissue } \\
\text { disorders }\end{array}$ \\
\hline $\begin{array}{l}\text { Vemurafenib followed by } \\
\text { ipilimumab in V600 BRAF } \\
\text { mutant, untreated } \\
\text { metastatic melanoma } \\
\text { patients [130] }\end{array}$ & Completed & BMS & II, NCT01673854 & $\begin{array}{l}\text { The study was divided into two parts: one where patients received } \\
\text { vemurafenib followed by ipilimumab and the other where subjects } \\
\text { who progressed after ipilimumab received vemurafenib. The } \\
\text { sequential treatment was efficacious and had a manageable safety } \\
\text { profile. The use of targeted therapy followed by immune } \\
\text { modulation therapy has helped to understand the optimum } \\
\text { regimen of these therapies. VEM1-IPI: } 46 \text { patients were treated } \\
\text { with vemurafenib followed by } 46 \text { patients on ipilimumab induction } \\
\text { and eight patients on ipilimumab maintenance. The median } \\
\text { duration of response and follow-up was } 23.1 \text { months ( } 95 \% \text { CI: } \\
\text { 5.03-not reached). The BOR was } 32.6 \% \text {. The median PFS and OS } \\
\text { was } 4.5 \text { months (95\%CI: 4.17-6.57 months) and } 18.5 \text { months (95\%CI: } \\
\text { 11.96-not evaluated). VEM2: } 19 \text { patients progressed on pilimumab } \\
\text { were treated with vemurafenib. The median follow-up and overall } \\
\text { survival was } 15.3 \text { months and } 18.5 \text { months ( } 95 \% \text { CI: } 11.96-\text { not } \\
\text { evaluated) respectively. The median PFS was } 4.5 \text { months ( } 95 \% \text { CI: } \\
4.17-6.57 \text { months). The BOR rate was } 36.8 \% \text {. } 4.3 \% \text { of patients had a } \\
\text { CR and } 28.3 \% \text { had a PR. }\end{array}$ & $\begin{array}{l}\text { Rash, erythema, pruritus, GI } \\
\text { toxicities, hetaobiliary toxicities, } \\
\text { nausea, vomiting. }\end{array}$ \\
\hline
\end{tabular}


Table 1. Cont

\begin{tabular}{|c|c|c|c|c|c|}
\hline Treatment & Status & Sponsor & Phase and NCT & Clinical Outcomes & Adverse Events \\
\hline $\begin{array}{l}\text { Ipilimumab in combination } \\
\text { with HF-10 (replication } \\
\text {-competent HSV-1 oncolytic } \\
\text { virus) in stage IIIb/c/IV } \\
\text { unresectable or metastatic } \\
\text { malignant melanoma [131] }\end{array}$ & Completed & $\begin{array}{l}\text { Takara Bio Inc. in } \\
\text { collaboration with } \\
\text { Theradex }\end{array}$ & II, NCT02272855 & $\begin{array}{l}\text { The combination was well tolerated, beneficial and elicited } \\
\text { anti-tumor activity. The combination induced an immune-cell } \\
\text { infiltration in the TME. } 46 \text { patienrs were enrolled. The best overall } \\
\text { response rate was at } 24 \text { weeks. Immune-related response criteria: } \\
18 \% \text { and } 23 \% \text { of the patients had a CR and PR respectively. The } \\
\text { median PFS and OS were } 19 \text { months and } 26 \text { months respectively. } \\
\text { There was increase om the total tumor infiltrating CD } 8+\text { T-cells and } \\
\text { lymphocytes along with a decrease in the CD4+ T-cells. }\end{array}$ & $\begin{array}{l}\text { Treatment related grade } 3 / 4 \\
\text { events. Majority of the AEs } \\
\text { were due to Ipilimumab which } \\
\text { are immune related events. }\end{array}$ \\
\hline $\begin{array}{l}\text { Ipilimumab in combination } \\
\text { with standard melphalan } \\
\text { and dactinomycin to isolate } \\
\text { limb infusion (ILI) for } \\
\text { advanced unresectable } \\
\text { melanoma of the extremity } \\
\text { [132] }\end{array}$ & Completed & $\begin{array}{l}\text { Memorial Sloan } \\
\text { Kettering Cancer } \\
\text { Center in } \\
\text { collaboration with } \\
\quad \text { BMS }\end{array}$ & II, NCT01323517 & $\begin{array}{l}\text { The combination was safe and efficacious. } 18 \text { patients were } \\
\text { enrolled. The median follow-up time was } 18 \text { months. At } 3 \text { months } \\
\text { timepoint, } 89 \% \text { of the patients had a limb response from which } 65 \% \\
\text { and } 24 \% \text { had a CR and PR, respectively. At } 18 \text { months, the median } \\
\text { OS was } 78 \% \text {. The PFS at one year was } 57 \% \text {. The levels of } \\
\text { eosinophils and ALC were elevated in all the subjects. }\end{array}$ & $\begin{array}{l}\text { Limb toxicity, colitis, } \\
\text { hypophysitis, rash. }\end{array}$ \\
\hline $\begin{array}{c}\text { Ipilimumab in Japanese } \\
\text { patients with unresectable } \\
\text { or metastatic melanoma } \\
\text { [133] }\end{array}$ & Completed & BMS & II, NCT01990859 & $\begin{array}{l}\text { Ipilimumab was well tolerated and demonstrated an anti-tumor } \\
\text { response in these patients }(n=20) \text {. The median OS and PFS was } \\
8.71 \text { months ( } 95 \% \text { CI: } 3.71-n r \text { months) and } 2.74 \text { months }(95 \% \text { CI: } \\
1.25-2.83 \text { months) respectively. The disease control rate and best } \\
\text { overall response rates were } 20 \% \text { ( } 95 \% \text { CI: } 5.7-43.7) \text { and } 10 \% \text { ( } 95 \% \\
\text { CI: } 1.2-31.7 \text { ) respectively. } 10 \% \text { of the subjects had a CR. }\end{array}$ & $\begin{array}{l}\text { Rash, pruritus, pyrexia, GI } \\
\text { disorder, increase in AST and } \\
\text { ALT, skin, liver and endocrine } \\
\text { related immune events. No } \\
\text { grade } 4 \text { drug related adverse } \\
\text { events were observed. }\end{array}$ \\
\hline $\begin{array}{l}\text { Ipilimumab in combination } \\
\text { with temozolamide in } \\
\text { metastatic melanoma } \\
\text { patients }[134,135]\end{array}$ & Completed & $\begin{array}{c}\text { M.D. Anderson } \\
\text { Cancer Center in } \\
\text { collaboration with } \\
\text { BMS }\end{array}$ & II, NCT01119508 & $\begin{array}{l}\text { The combination exhibited an enhanced antitumor activity. } 64 \\
\text { patients were enrolled. The median duration of response and } \\
\text { median follow-up was } 35 \text { months (Range: } 2-57 \text { months) and } 20 \\
\text { months (Range: } 2-60 \text { months). } 15.6 \% \text { of the subjects had a CR and } \\
\text { PR. The median PFS and OS was } 5 \text { months and } 24.5 \text { months } \\
\text { respectively. } 6 \text { months PFS was } 45 \% \text {. The PFS for patients with } \\
\text { bone metastasis was significantly decreased ( } p=0.014 \text { ) but not for } \\
\text { subjects with liver metastasis. } 21 \% \text { and } 7 \% \text { of the subjects with } \\
\text { liver metastasis had a CR and PR respectively while no ORR was } \\
\text { observed in subjects with bone metastasis }\end{array}$ & $\begin{array}{l}\text { Pruritus, skin rash, nausea, } \\
\text { constipation, diarrhea, colitis, } \\
\text { increase in ALT and AST, } \\
\text { hematologic toxicities. No drug } \\
\text { related grade } 5 \text { toxicities were } \\
\text { observed. }\end{array}$ \\
\hline
\end{tabular}


Table 1. Cont.

\begin{tabular}{|c|c|c|c|c|c|}
\hline Treatment & Status & Sponsor & Phase and NCT & Clinical Outcomes & Adverse Events \\
\hline $\begin{array}{l}\text { Ipilimumab as } \\
\text { monotherapy for previously } \\
\text { treated unresectable stage } \\
\text { III/IV melanoma [136,137] }\end{array}$ & Completed & $\begin{array}{c}\text { BMS in } \\
\text { collaboration with } \\
\text { Medarex }\end{array}$ & II, NCT00289627 & $\begin{array}{l}\text { Ipilimumab demonstrated good clinical activity in these patients } \\
\text { which consists of subjects who did not respond to prior therapy. } \\
155 \text { patients were enrolled in the study. The median follow-up and } \\
\text { OS was } 10 \text { months (Range } 0.32-33.1 \text { months) and } 10.2 \text { months ( } 95 \% \\
\text { CI: } 7.6-16.3 \%) \text {. The best overall response rate and disease control } \\
\text { rate was } 5.8 \% \text { ( } 95 \% \text { CI: } 2.7-10.7 \% \text { ) and } 27 \% \text { ( } 95 \% \text { CI: } 20-35 \%) \\
\text { respectively. } 5.8 \% \text { of the subjects had a PR and no CR was } \\
\text { observed. The } 1 \text { year, } 18 \text { months and } 2 \text { year survival rates were } \\
47.2 \% \text { (95\% CI: } 39.5-55.1 \%), 39.4 \% \text { (95\% CI: } 31.7-47.2 \% \text { ) and } 32.8 \% \\
\text { (95\% CI: } 25.4-40.5 \%) \text {, respectively. }\end{array}$ & $\begin{array}{l}\text { Immune related grade } 3 \text { and } 4 \\
\text { events - skin and GI tract, liver } \\
\text { and endocrine. No grade } 5 \\
\text { immune related adverse events } \\
\text { were observed. }\end{array}$ \\
\hline $\begin{array}{l}\text { Ipilimumab in combination } \\
\text { with autologous TriMix } \\
\text {-DC therapeutic vaccine for } \\
\text { previously treated } \\
\text { unresectable stage III/IV } \\
\text { melanoma }[138,139]\end{array}$ & Completed & $\begin{array}{c}\text { Bart Neyns, } \\
\text { Universitair } \\
\text { Ziekenhuis Brussel } \\
\text { in collaboration } \\
\text { with Vrije } \\
\text { Universiteit } \\
\text { Brussel }\end{array}$ & II, NCT01302496 & 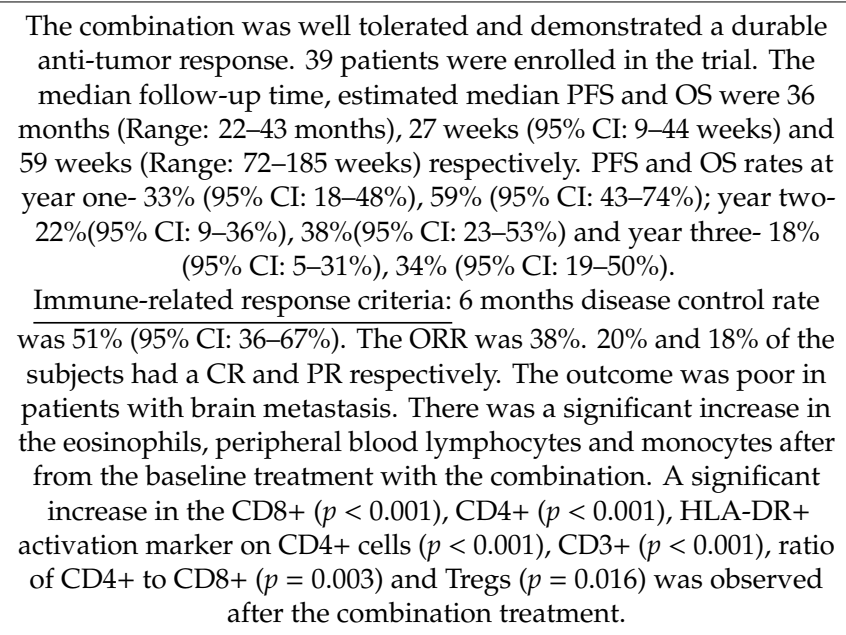 & $\begin{array}{l}\text { Dermal injection site reactions, } \\
\text { post-infusion chills, flu-like } \\
\text { symptoms. Immune related } \\
\text { adverse events- dermatitis, } \\
\text { colitis, diarrhea, hypophysitis, } \\
\text { neumonitis, lymphadenopathy } \\
\text { Grade } 3 / 4 \text { immune related } \\
\text { adverse events were observed } \\
\text { with no grade } 5 \text { events. }\end{array}$ \\
\hline $\begin{array}{l}\text { Ipilimumab in combination } \\
\text { with WBRT for melanoma } \\
\text { patients and brain } \\
\text { metastases (GEM STUDY, } \\
\text { GRAY-B) }[140,141]\end{array}$ & Completed & $\begin{array}{l}\text { Grupo Español } \\
\text { Multidisciplinar } \\
\text { de Melanoma in } \\
\text { collaboration with } \\
\text { BMS }\end{array}$ & II, NCT02115139 & $\begin{array}{l}\text { The combination was well tolerated and safe. Fifty eight patients } \\
\text { were enrolled in the study. The overall survival at } 1 \text { year was } 31.8 \% \\
\text { (95\% CI: } 18.8-44.8 \% \text { ). The median OS and PFS was 5.8 months } \\
\text { ( } 95 \% \text { CI: 3.6-5.9 months) and } 4.8 \text { months (95\% CI: } 2.2-3.4 \text { months). }\end{array}$ & $\begin{array}{l}\text { WBRT related- vomiting and } \\
\text { headache. } \\
\text { Immune therapy related- } \\
\text { diarrhea, intestinal perforation } \\
\text { increase in AST and ALT, } \\
\text { headache. }\end{array}$ \\
\hline
\end{tabular}


Table 1. Cont.

\begin{tabular}{|c|c|c|c|c|c|}
\hline Treatment & Status & Sponsor & Phase and NCT & Clinical Outcomes & Adverse Events \\
\hline $\begin{array}{l}\text { Ipilimumab in combination } \\
\text { with SRS for subjects with } \\
\text { brain metastasis [142] }\end{array}$ & Completed & $\begin{array}{l}\text { University } \\
\text { Hospital, Lille in } \\
\text { collaboration with } \\
\text { BMS }\end{array}$ & II, NCT02662725 & $\begin{array}{c}\text { High dose of ipilimumab and SRS was effective with a manageable } \\
\text { safety profile. } 57 \text { patients were enrolled in the study. Median } \\
\text { survival time for reference population vs study population was } 5.6 \\
\text { months vs } 13.2 \text { months (HR: } 0.29,95 \% \text { CI: } 0.19-0.39 ; p<0.0001 \text { ) } \\
\text { with } 49 \% \text { disease control rate. }\end{array}$ & $\begin{array}{l}\text { Colitis, hepatitis, hypophiisitis, } \\
\text { headache. One subject showed } \\
\text { radionecrosis. }\end{array}$ \\
\hline $\begin{array}{l}\text { Ipilumumab alone or in } \\
\text { combination with } \\
\text { decarbazine in previously } \\
\text { untreated metastatic } \\
\text { melanoma patients [143] }\end{array}$ & Completed & BMS & II, NCT00050102 & $\begin{array}{l}\text { The combination was well tolerated and a durable, clinically } \\
\text { meaningful responses were observed. Decarbazine did not affect } \\
\text { the PK of ipilimumab. Ipilimumab alone }(n=37) \text { : The median } \\
\text { follow up time and median OS were } 16.4 \text { months and } 11.4 \text { months } \\
(95 \% \text { CI: } 6.1-15.6 \text { months) respectively. The objective response rate } \\
\text { and disease control rate were } 5.4 \% \text { ( } 95 \% \text { CI: } 0.7-18.2 \%) \text { and } 21.6 \% \\
(95 \% \text { CI: } 9.8-38.2 \%) \text {, respectively. } 5.4 \% \text { of the subjects had a PR. } \\
\text { The survival rates for } 1 \text { year, } 2 \text { year and } 36 \text { months were } 45 \%, 21 \% \\
\text { and 9\%, respectively. } \\
\text { Combination ( } n=35) \text { : The median follow up time and the OS were } \\
20.9 \text { months and } 14.3 \text { months ( } 95 \% \text { CI: } 10.2-18.8 \text { month) } \\
\text { respectively. The objective response rate and disease control rate } \\
\text { was } 14.3 \%(95 \% \text { CI: } 4.8-30.3 \% \text { ) and } 37.1 \% \text { ( } 95 \% \text { CI: } 21.5-55.1 \%) \\
\text { respectively. } 5.7 \% \text { and } 8.6 \% \text { of the patients had a CR and PR for } \\
\text { more than } 24 \text { weeks respectively. The survival rates for } 1 \text { year, } 2 \\
\text { year and } 36 \text { months were } 62 \%, 24 \% \text { and } 20 \% \text { respectively. } \\
\text { CD4+ and CD8+ expressing HLA-DR T cells were increased in } \\
\text { both the groups. }\end{array}$ & $\begin{array}{l}\text { Colitis, muscle weakness, } \\
\text { anemia, tachycardia, abdominal } \\
\text { pain. Fatigue, dehydration, } \\
\text { increased ALT/AST, rash, } \\
\text { pruritus, vasculitis. }\end{array}$ \\
\hline $\begin{array}{l}\text { Ipilimumab in combination } \\
\text { with HF10 for unresectable } \\
\text { Stage IIIb/c/IV or metastatic } \\
\text { malignant melanoma [144] }\end{array}$ & Completed & $\begin{array}{l}\text { Takara Bio Inc. in } \\
\text { collaboration with } \\
\text { Theradex }\end{array}$ & II, NCT02272855 & $\begin{array}{l}\text { The combination was well tolerated with positive antitumor } \\
\text { activity and there were no dose limiting toxicities. } 46 \text { patients were } \\
\text { enrolled. The median PFS and OS was } 19 \text { months and } 21.8 \text { months } \\
\text { respectively. Immune-related response criteria: The best overall } \\
\text { response rate and disease stability rate was } 41 \% \text { and } 68 \% \text {, } \\
\text { respectively. } 16 \% \text { and } 25 \% \text { of the patients had CR and PR, } \\
\text { respectively. }\end{array}$ & $\begin{array}{l}\text { Embolism, lymphedema, } \\
\text { diarrhea, hypoglycemia, groin } \\
\text { pain, immune related events. }\end{array}$ \\
\hline
\end{tabular}


Table 1. Cont.

\begin{tabular}{|c|c|c|c|c|c|}
\hline Treatment & Status & Sponsor & Phase and NCT & Clinical Outcomes & Adverse Events \\
\hline $\begin{array}{l}\text { Decarbazine alone or in } \\
\text { combination with } \\
\text { ipilimumab for unresectable } \\
\text { stage III/IV melanoma [145] }\end{array}$ & Completed & $\begin{array}{c}\text { BMS in } \\
\text { collaboration with } \\
\text { Medarex }\end{array}$ & II, NCT00324155 & $\begin{array}{l}\text { The combination of ipilimumab and decarbazine was well } \\
\text { tolerated and had a long-term durable overall survival. } \\
\text { Ipilimumab and decarbazine group }(n=250) \text { : The median } \\
\text { survival follow-up time and OS was } 11 \text { months (Range: } 0.4-71.9 \\
\text { months) and } 11.2 \text { months ( } 95 \% \text { CI: } 9.5-13.8 \text { months) respectively. } \\
\text { At } 5 \text { years, } 18.2 \% \text { of the patients were alive which was significantly } \\
\text { higher than that in the other group ( } p=0.002) .7 .5 \% \text { and } 42.5 \% \text { of } \\
\text { the patients had a CR and PR respectively. No median OS was } \\
\text { reached for the responders while that for the non-responders was } \\
\text { was } 14.3 \text { months ( } 95 \% \text { CI: } 11.4-16.9 \text { months; HR: } 0.28,95 \% \text { CI: } \\
\text { 0.16-0.47). Decarbazine and placebo group ( } n=252) \text { : The median } \\
\text { survival follow-up time and OS was } 8.9 \text { months (Range: } 0.1-73.2 \\
\text { months) and } 9.1 \text { months ( } 95 \% \text { CI: } 7.8-10.5 \text { months; HR: } 0.69 ; 95 \% \\
\text { CI: } 0.57-0.84 \text { ) respectively. At } 5 \text { years, } 8.8 \% \text { of the patients were } \\
\text { alive. } 35 \% \text { of the patients had a PR and no CR was achieved. The } \\
\text { median OS for non responders and responders was } 12.3 \text { months } \\
\text { (95\% CI: } 10.9-15.4 \text { months) and } 20.2 \text { months ( } 95 \% \text { CI: } 14.6-45.3 \\
\text { months; HR: } 0.51,95 \% \text { CI: } 0.32-0.84) \text {, respectively. }\end{array}$ & $\begin{array}{l}\text { Rash, pruritus, vitiligo, GI, liver } \\
\text { and endocrine related events. } \\
\text { Grade } 3 \text { to } 4 \text { immune related } \\
\text { adverse events were observed } \\
\text { in skin with no grade } 5 \text { events. }\end{array}$ \\
\hline $\begin{array}{l}\text { Ipilimumab antibody } \\
\text { (MDX-010) alone or in } \\
\text { combination with } \\
\text { melanoma peptide vaccine } \\
\text { (MDX-1379; gp100) for } \\
\text { previously untreated } \\
\text { unresectble stage III/IV } \\
\text { melanoma [146] }\end{array}$ & Completed & BMS & III, NCT00094653 & $\begin{array}{l}\text { Overall ipilimumab resulted in survival of } 20 \% \text { of the patients for } \\
\text { more than } 2 \text { years. } 45 \% \text { of the patients who survived for more than } \\
22 \text { years survived for more than } 3 \text { years. } \\
\text { Ipilimumab + placebo }(n=137): 25 \% \text { of the patients survived for } \\
\text { more than } 2 \text { years and } 3 \text { years. The disease control rate for } \\
\text { on-study response and for patients surviving more than } 2 \text { years } \\
\text { was } 28.5 \%(1.5 \% \text { CR and } 9.5 \% \text { PR) and } 83.3 \%(8.3 \% \text { CR and } 41.7 \% \\
\text { PR) respectively. Gp100 vaccine alone }(n=136): 17 \% \text { and } 10 \% \text { of } \\
\text { the patients survived for more than } 2 \text { year and } 3 \text { years respectively. } \\
\text { The disease control rate for on-study response and for patients } \\
\text { surviving more than } 2 \text { years was } 11 \%(1.5 \% \text { PR) and } 43.8 \% \text {, } \\
\text { respectively. Combination }(n=403): 19 \% \text { and } 15 \% \text { of the patients } \\
\text { survived for more than } 2 \text { years and } 3 \text { years respectively. The } \\
\text { disease control rate for on-study response and for patients } \\
\text { surviving more than } 2 \text { years was } 20.1 \%(0.2 \% \text { CR and } 5.5 \% \text { PR) and } \\
66.7 \%(1.9 \% \text { CR and } 22.2 \% \text { PR), respectively. }\end{array}$ & $\begin{array}{c}\text { Immune related adverse events- } \\
\text { colitis, vitiligo, diarrhea, } \\
\text { hypogonadism, proctitis, } \\
\text { dermatologic, GI, endocrine } \\
\text { related events, increase ALT. } \\
\text { No grade } 4 / 5 \text { immune related } \\
\text { adverse effects were observed. }\end{array}$ \\
\hline
\end{tabular}


Table 1. Cont.

\begin{tabular}{|c|c|c|c|c|c|}
\hline Treatment & Status & Sponsor & Phase and NCT & Clinical Outcomes & Adverse Events \\
\hline $\begin{array}{l}\text { Ipilimumab doses- } 3 \mathrm{mg} / \mathrm{kg} \\
\text { vs } 10 \mathrm{mg} / \mathrm{kg} \text { for previously } \\
\text { treated or untreated } \\
\text { unresectable or metastatic } \\
\text { melanoma [147] }\end{array}$ & Completed & BMS & III, NCT01515189 & 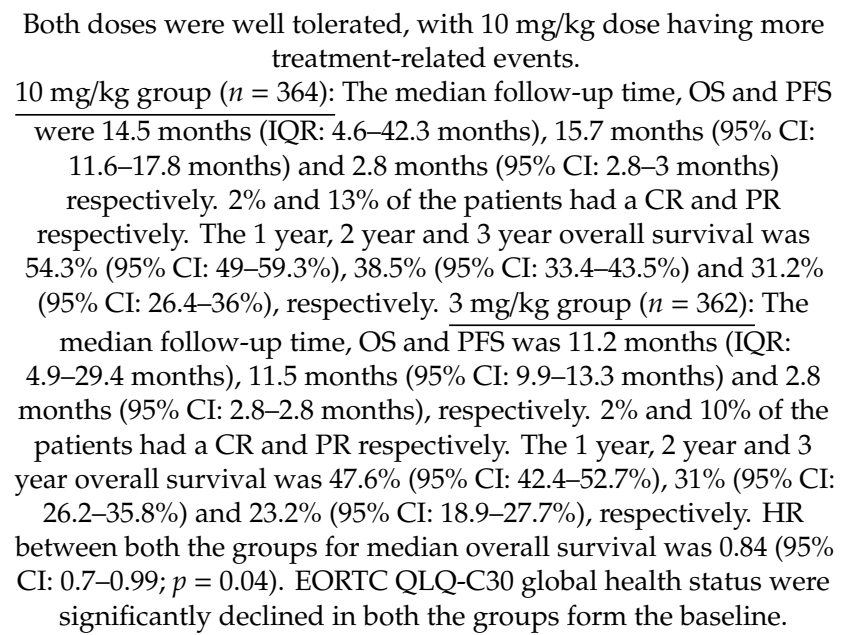 & $\begin{array}{c}\text { Headache, diarrhea, colitis, } \\
\text { increase in ALT, hypophysitis. } \\
\text { No grade } 5 \text { toxicities were } \\
\text { observed. }\end{array}$ \\
\hline $\begin{array}{l}\text { Ipilimumab alone or in } \\
\text { combination with } \\
\text { talimogene laherparepvec } \\
\text { (T-VEC) in patients with } \\
\text { previously untreated } \\
\text { unresected, Stage IIIb-IV } \\
\text { melanoma [148] }\end{array}$ & $\begin{array}{c}\text { Active, } \\
\text { not } \\
\text { recruiting }\end{array}$ & Amgen & $\begin{array}{c}\mathrm{Ib} / \mathrm{II} \\
\text { NCT01740297 }\end{array}$ & $\begin{array}{l}\text { The combination was well tolerated and had a greater systemic } \\
\text { antitumor response (in uninjected and visceral lesions) as } \\
\text { compared to single agent. Ipilimumab + Laherparepvec }(n=98) \text { : } \\
\text { The median duration of treatment with laherparepved and } \\
\text { ipilimumab was } 21.1 \text { and } 9.1 \text { weeks, respectively. The median } \\
\text { followup time and time to response was } 68 \text { weeks (Range: } 0-156 \\
\text { weeks) and } 5.8 \text { months ( } 95 \% \text { CI: } 5.4-10.9 \text { months) respectively. } 39 \% \\
\text { of the patients had an ORR ( } 13 \% \text { CR and } 26 \% \text { PR) and visceral } \\
\text { lesions decrease was observed in } 52 \% \text { of the patient population. } \\
\text { The median PFS was } 8.2 \text { months ( } 95 \% \text { CI: } 4.2-21.5 \text { months). } \\
\text { Ipilimumab alone ( } n=100) \text { : The median duration of treatment of } \\
\text { ipilumumab was } 9.1 \text { weeks. The median followup time was } 58 \\
\text { weeks (Range: } 0-152 \text { weeks). The median time to response was not } \\
\text { estimated (HR }=1.41 ; 95 \% \text { CI: } 0.8-2.5) .18 \% \text { of the patients had an } \\
\text { ORR ( } 7 \% \text { CR and } 11 \% \text { PR; OR: } 2.9,95 \% \text { CI: } 1.5-5.5, p=0.002) \text { and } \\
\text { visceral lesion decrease was observed in } 23 \% \text { of the patient } \\
\text { population. The median PFS was } 6.4 \text { months (95\% CI: } 4.2-21.5 \\
\text { months). }\end{array}$ & $\begin{array}{l}\text { Fatigue, chills, GI disorders, } \\
\text { pruritus, rash and nausea. }\end{array}$ \\
\hline
\end{tabular}


Table 1. Cont.

\begin{tabular}{|c|c|c|c|c|c|}
\hline Treatment & Status & Sponsor & Phase and NCT & Clinical Outcomes & Adverse Events \\
\hline $\begin{array}{l}\text { Ipilimumab in Stage IV } \\
\text { melanoma patients } \\
\text { receiving palliative } \\
\text { radiation therapy [149] }\end{array}$ & $\begin{array}{l}\text { Active, } \\
\text { not } \\
\text { recruiting }\end{array}$ & $\begin{array}{l}\text { Stanford } \\
\text { University }\end{array}$ & II, NCT01449279 & $\begin{array}{l}\text { The combination was safe and efficacious. } 22 \text { patients were } \\
\text { enrolled and treated in the study. } 50 \% \text { of the patients had benefited } \\
\text { from the therapy including CR and PR at } 55 \text { week follow-up. } 27.3 \% \\
\text { of the patients had an ongoing systemic complete response to the } \\
\text { combination ( } 95 \% \text { CI- } 9.7-56.9 \% \text { ) with no evidence of disease at } 55 \\
\text { week. } 27.3 \% \text { ( } 95 \% \text { CI- } 9.7-56.96 \% \text { ) of the patients has an initial PR } \\
\text { without progression for median of } 40 \text { weeks (Range: } 29-53 \text { ). The } \\
\text { median PFS was } 26 \text { weeks (Range: } 2-65 ; 95 \% \text { CI: } 16.3-35.7 \text { and the } \\
\text { median overall survival was } 55 \text { weeks (Range: } 8-141 ; 95 \% \text { CI: } \\
\text { 39.2-70.8) with the patients receiving the combination. The median } \\
\text { time for response for patients who had CR or PR was } 19 \text { weeks } \\
\text { (Range: } 12-52 \text { ). The strong antitumor response in patients with CR } \\
\text { or PR can be attributed to increased levels of IL-2 producing CD } 8+ \\
\text { T cells and central memory CD } 8+\text { T cells in comparison to patients } \\
\text { with melanoma could be used as biomarkers further. }\end{array}$ & $\begin{array}{l}\text { Colitis, hypophysitis, rash, } \\
\text { anemia, nausea and radiation } \\
\text { dermatitis. }\end{array}$ \\
\hline $\begin{array}{l}\text { Ipilimumab alone or in } \\
\text { combination with } \\
\text { sargramostim (GM-CSF) in } \\
\text { Stage III/IV melanoma that } \\
\text { cannot be removed } \\
\text { surgically [150] }\end{array}$ & $\begin{array}{l}\text { Active, } \\
\text { not } \\
\text { recruiting }\end{array}$ & $\mathrm{NCI}$ & II, NCT01134614 & $\begin{array}{l}\text { The combination was advantageous and had a lower toxicity } \\
\text { profile. The median follow-up was } 13.3 \text { months (Range: } 0.03-19.9 \\
\text { months). Ipilimumab + Sargarmostim }(n=132) \text { : The median OS } \\
\text { was } 17.5 \text { months ( } 95 \% \text { CI: } 14.9 \text {-not reached). The one year survival } \\
\text { rate was } 68.9 \% \text { ( } 95 \% \text { CI: } 60.6-85.5 \%) \text {. } \\
\text { Ipilimumab alone }(n=122) \text { : The median OS was } 12.7 \text { months }(95 \% \\
\text { CI: } 10-\text { not reached). The one year survival rate was } 52.9 \%(95 \% \text { CI: } \\
\text { 43.6-62.2\%). There was no difference in PFS across both the groups. }\end{array}$ & $\begin{array}{l}\text { GI toxicity, pulmonary } \\
\text { toxicities, }\end{array}$ \\
\hline $\begin{array}{l}\text { Ipilimumab as adjuvant } \\
\text { therapy after complete } \\
\text { resection of high risk stage } \\
\text { III melanoma [151] }\end{array}$ & $\begin{array}{c}\text { Active, } \\
\text { not } \\
\text { recruiting }\end{array}$ & BMS & III, NCT00636168 & $\begin{array}{l}\text { Addition of Ipilimumab as adjuvant therapy benefited patients } \\
\text { with microscopic involvement only (sentinel node-positive) and for } \\
\text { patient with macroscopic or palpable nodes. The median follow up } \\
\text { was } 5.3 \text { years. } \\
\text { Ipilimumab group ( } n=475) \text { : The } 5 \text { years recurrence-free survival } \\
\text { and OS was } 40.8 \% \text { and } 65.4 \% \text { respectively. The rate of distant } \\
\text { metastasis free survival at } 5 \text { years was } 48.3 \% \text {. } \\
\text { Placebo group }(n=476) \text { : The } 5 \text { years recurrence free survival and } \\
\text { OS was } 30.3 \% \text { (HR: } 0.76 ; 95 \% \text { CI: } 0.64-0.89 ; p<0.001 \text { ) and } 54.4 \% \\
\text { (HR: } 0.72 ; 95 \% \text { CI: } 0.58-0.88 ; p=0.001 \text { ) respectively. The rate of } \\
\text { distant metastasis free survival at } 5 \text { years was } 38.9 \% \text { (HR: } 0.76 ; 95 \% \\
\text { CI: } 0.64-0.92 ; p=0.002 \text { ). }\end{array}$ & $\begin{array}{l}\text { Immune related adverse events- } \\
\text { GI, hepatic, endocrine, skin and } \\
\text { neurologic. }\end{array}$ \\
\hline
\end{tabular}


Table 1. Cont.

\begin{tabular}{|c|c|c|c|c|c|}
\hline Treatment & Status & Sponsor & Phase and NCT & Clinical Outcomes & Adverse Events \\
\hline \multicolumn{6}{|c|}{ Combination of Anti-PD-1/PD-L1 and anti-CTLA-4 } \\
\hline $\begin{array}{l}\text { Ipilimumab in low dose as } \\
\text { an adjuvant in combination } \\
\text { with nivolumab after } \\
\text { resection of melanoma } \\
\text { macrometastases [152] }\end{array}$ & Completed & $\begin{array}{c}\text { Universitair } \\
\text { Ziekenhuis Brussel }\end{array}$ & Ib, NCT02941744 & $\begin{array}{l}\text { Ipilumumab at low doses in combination with nivolumab had an } \\
\text { acceptable safety profile. } \\
\text { Ipilumumab (50 mg) + Nivolumab }(10 \mathrm{mg})(n=34) \text { : the median } \\
\text { follow up was } 86 \text { weeks. One year relapse-free survival, overall } \\
\text { survival and distant metastasis-free survival was } 55 \% \text { ( } 95 \% \text { CI: } \\
39-72 \%) ; 97 \%(95 \% \text { CI: } 94-100 \%) \text { and } 79 \%(95 \% \text { CI: } 65-92 \%) \\
\text { respectively. Median relapse free survival was } 84 \text { weeks }(95 \% \text { CI: } \\
28-139 \text { weeks). Nivolumab }(10 \mathrm{mg})(n=22) \text { : The median follow } \\
\text { up was } 36 \text { weeks. One year relapse-free survival and overall } \\
\text { survival was } 78 \%(95 \% \text { CI: } 73-82 \%) \text { and } 100 \% \text { respectively. Distant } \\
\text { metastasis was not observed. The median relapse free survival was } \\
\text { not reached. }\end{array}$ & $\begin{array}{l}4-8 \% \text { grade } 3 \text { immune related } \\
\text { adverse events were across both } \\
\text { the cohorts. }\end{array}$ \\
\hline $\begin{array}{c}\text { LTX-315 alone or in } \\
\text { combination with } \\
\text { Ipilimumab or } \\
\text { Pembrolizumab in patients } \\
\text { with transdermally } \\
\text { accessible tumors }[153,154]\end{array}$ & Completed & $\begin{array}{c}\text { Lytix Biopharma } \\
\text { AS in collaboration } \\
\text { with Theradex and } \\
\text { ICON plcI }\end{array}$ & I, NCT01986326 & $\begin{array}{l}\text { Combination of immune checkpoint inhibitors with LTX-315 was } \\
\text { safe and tolerable and demonstrated a potent anti-tumor activity. } \\
\text { Of } 6 \text { melanoma patients received LTX-315 in combination with } \\
\text { Ipilimumab, stable disease was observed in } 33 \% \text { of the patients. } \\
\text { LTX-315 when administered to patients with solid tumors resulted } \\
\text { in increase in number of CD8+ T cells at the site of treated lesions } \\
\text { along with tumor infiltrating lymphocyte population. Clonal } \\
\text { expansion of T-cells in blood was observed after treatment with } \\
\text { LTX-315 as revealed by T-cell receptor sequencing. }\end{array}$ & $\begin{array}{c}\text { LTX-315-related grade } 3 \text { and } 4 \\
\text { adverse events } \\
\text { (allergic/anaphylaxis) were } \\
\text { observed along with tingling } \\
\text { post injection, rash, fatigue, } \\
\text { diarrhea, hypo and hyper } \\
\text { tension, weakness. }\end{array}$ \\
\hline $\begin{array}{l}\text { Nivolumab and Ipilimumab } \\
\text { alone or in combination in } \\
\text { patients with previously } \\
\text { untreated unresectable or } \\
\text { metastatic melanoma } \\
\text { (CheckMate067) [155] }\end{array}$ & $\begin{array}{l}\text { Active, } \\
\text { not } \\
\text { recruiting }\end{array}$ & BMS & III, NCT01844505 & $\begin{array}{c}\text { Combination of ipilimumab and nivolumab or nivolumab alone } \\
\text { was superior over monotherapy with ipilimumab. No new toxic } \\
\text { effects associated with chronic use of these therapies were observed. } \\
\text { Nivolumab plus Ipilimumab group }(n=314) \text { : Median overall } \\
\text { survival was more than } 60 \text { months. Hazard ratio for death versus } \\
\text { Ipilimumab group was } 0.52 .5 \text { year overall survival rate was } 52 \% \text {. } \\
\text { Nivolumab group }(n=316) \text { : Median overall survival was } 36.9 \\
\text { months. Hazard ratio for death versus Ipilimumab group was } 0.63 \text {. } \\
5 \text { year overall survival rate was } 44 \% \text {. Ipilimumab group }(n=315) \text { : } \\
\text { Median overall survival was } 19.9 \text { months. } 5 \text { year overall survival } \\
\text { rate was } 26 \% \text {. }\end{array}$ & \\
\hline
\end{tabular}


Table 1. Cont

\begin{tabular}{|c|c|c|c|c|c|}
\hline Treatment & Status & Sponsor & Phase and NCT & Clinical Outcomes & Adverse Events \\
\hline $\begin{array}{l}\text { Ipilimumab in combination } \\
\text { with Nivolumab in patients } \\
\text { with unresectable Stage } \\
\text { III/IV malignant melanoma } \\
\text { [156] }\end{array}$ & $\begin{array}{c}\text { Active, } \\
\text { not } \\
\text { recruiting }\end{array}$ & $\begin{array}{c}\text { BMS in } \\
\text { collaboration with } \\
\text { Medarex and Ono } \\
\text { Pharma USA Inc }\end{array}$ & Ib, NCT01024231 & $\begin{array}{l}\text { The combination of Ipilimumab and nivolumab had durable } \\
\text { clinical activity in patients with advanced melanoma. } 94 \text { patients } \\
\text { were enrolled in the study. At the target lesions, the mean } \\
\text { reduction in tumor burden was around } 64.7 \% \text {. The median } \\
\text { follow-up was } 30.3 \text { to } 55 \text { months while the median OS was not } \\
\text { reached at } 3 \text { years. The median PFS was } 6.2 \text { months ( } 95 \% \text { CI: } 3.2-11 \\
\text { months). The median duration of response was } 22.3 \text { months }(95 \% \\
\text { CI: } 13.8-25.8 \text { months). The best overall response rate and objective } \\
\text { response rate by modified WHO criteria were } 19.1 \% \text { and } 41.5 \% \\
\text { (95\% CI: } 31.4-52.1 \%) \text {. The CR and PR rates were } 22.3 \% \text { and } 16 \% \\
\text { respectively. The OS and median PFS rates at } 1 \text { year were } 81 \%(95 \% \\
\text { CI: } 71-87 \% \text { ) and } 37 \% \text { ( } 95 \% \text { CI: } 27-47 \% \text { ) respectively. The OS and } \\
\text { median PFS rates at } 2 \text { years were } 72 \% \text { ( } 95 \% \text { CI: } 62-80 \% \text { ) and } 28 \% \\
\text { (95\% CI: } 19-38 \% \text { ) respectively. The OS and median PFS at year } 3 \\
\text { were } 63 \% \text { (95\% CI: } 52-72 \% \text { ) and } 17 \% \text { (95\% CI: } 8-29 \%) \text { respectively. }\end{array}$ & $\begin{array}{c}\text { Grade } 3 \text { and } 4 \text { immune related } \\
\text { toxicities such as rash, diarrhea, } \\
\text { increase in lipase, AST, ALT } \\
\text { and amylase, rthralgia, colitis, } \\
\text { were observed. }\end{array}$ \\
\hline $\begin{array}{l}\text { Nivolumab alone or in } \\
\text { combination with } \\
\text { ipilimumab in melanoma } \\
\text { patients with brain } \\
\text { metastases [157] }\end{array}$ & $\begin{array}{l}\text { Active, } \\
\text { not } \\
\text { recruiting }\end{array}$ & $\begin{array}{c}\text { Melanoma } \\
\text { Institute Australia } \\
\text { in collaboration } \\
\text { with Melanoma } \\
\text { and Skin Cancer } \\
\text { Trials Limited and } \\
\text { BMS }\end{array}$ & II, NCT02374242 & 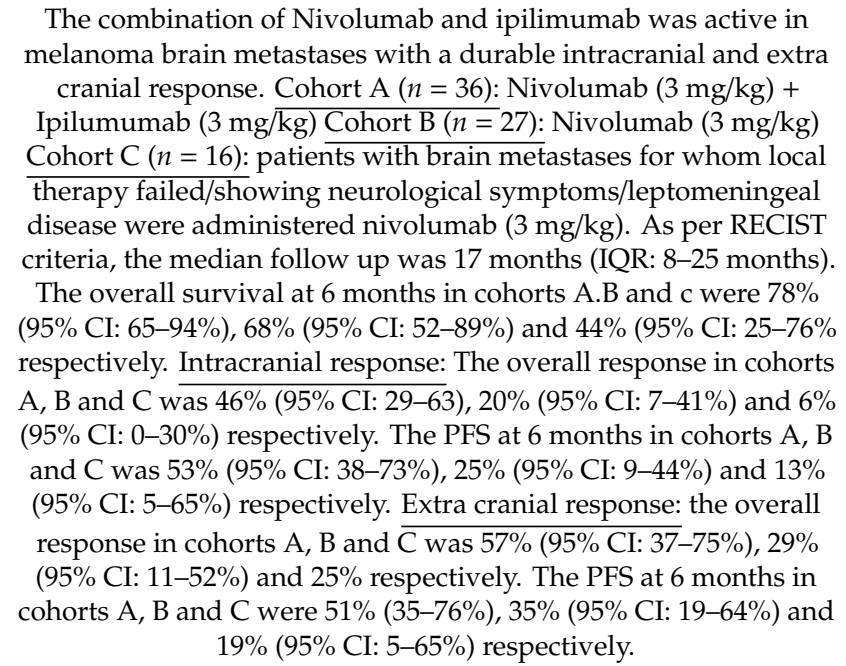 & $\begin{array}{l}\text { Grade } 1 \text { and } 2 \text { treatment related } \\
\text { adverse events were commonly } \\
\text { observed such as skin, GI, } \\
\text { endocrine, musculoskeletal, } \\
\text { respiratory related and fatigue. } \\
\text { Grade } 3 / 4 \text { related adverse } \\
\text { events were infrequent. }\end{array}$ \\
\hline
\end{tabular}


Table 1. Cont.

\begin{tabular}{|c|c|c|c|c|c|}
\hline Treatment & Status & Sponsor & Phase and NCT & Clinical Outcomes & Adverse Events \\
\hline $\begin{array}{l}\text { Pembrolizumab in } \\
\text { combination with reduced } \\
\text { dose Ipilimumab or } \\
\text { Pegylated Interferon } \\
\text { Alfa-2b in patients with } \\
\text { advanced melanoma } \\
\text { (KEYNOTE-29) [158] }\end{array}$ & $\begin{array}{l}\text { Active, } \\
\text { not } \\
\text { recruiting }\end{array}$ & $\begin{array}{l}\text { Merck Sharp \& } \\
\text { Dohme Corp. }\end{array}$ & I/II, NCT02089685 & $\begin{array}{l}\text { While the combination of Pembrolizumab and ipilimumab had } \\
\text { good antitumor activity and manageable safety profile, the } \\
\text { combination of pembrolizumab and PEF-INF did not. } \\
\text { Pembrolizumab and Ipilimumab }(n=12) \text { : The median follow-up } \\
\text { was } 25.1 \text { months (Range: } 0.8-38.7 \text { months). The median duration of } \\
\text { response was not reached. The objective response rate as per } \\
\text { independent central review was found to be } 42 \% \text { ( } 95 \% \text { CI: } 15-72 \%) \text {. } \\
\text { The CR and PR rates were } 8.33 \% \text { and } 33.33 \% \text { respectively. As per } \\
\text { investigator review, the objective response rate and PR were } 33 \% \\
\text { (95\% CI: } 10-655) \text { and } 33.33 \% \text { respectively. } \\
\text { Pembrolizumab and PEG-IFN ( } n=17) \text { : The median follow up was } \\
22.2 \text { months (Range- } 25-377 \text { months). As per central and } \\
\text { investigator review, the objective response rate was } 20 \% \text { and the } \\
\text { partial response rate was } 20 \% \text {. }\end{array}$ & $\begin{array}{c}\text { Pembrolizumab and Ipilimumab: } \\
\text { Grade } 1 / 2 \text { treatment related } \\
\text { adverse events- fatigue, } \\
\text { diarrhea, rash, nausea, colitis, } \\
\text { increased lipase, ALT and AST. } \\
\text { Immune-related adverse events- } \\
\text { colitis, hyper and hypo } \\
\text { thyroidism. } \\
\text { Pembrolizumab and PEG-IFN: } \\
\text { Treatment related AEs- } \\
\text { elevation is AST, ALT nerve } \\
\text { disorder, fatigue, chills, pyrexia, } \\
\text { diarrhea, rash, pruritus, nausea, } \\
\text { anemia. Immune-related AEs- } \\
\text { hyperthyroidism, pneumonitis, } \\
\text { hepatitis. }\end{array}$ \\
\hline $\begin{array}{l}\text { Nivolumab combined with } \\
\text { Ipilimumab or Ipilimumab } \\
\text { alone in patients with } \\
\text { untreated, unresectableor } \\
\text { metastatic melanoma [159] }\end{array}$ & $\begin{array}{l}\text { Active, } \\
\text { not } \\
\text { recruiting }\end{array}$ & BMS & II, NCT01927419 & 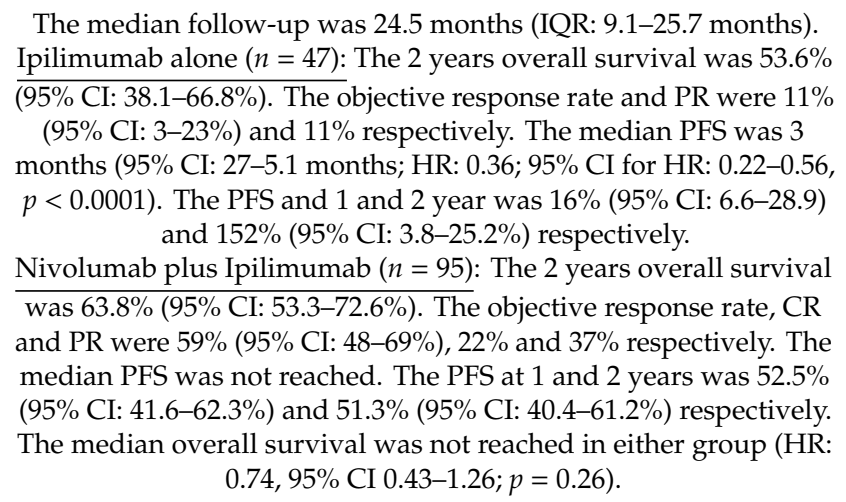 & $\begin{array}{l}\text { Colitis, Diarrhea, Hypophysitis, } \\
\text { Pneumonitis, Anaemia, } \\
\text { Hypothyrodism, increased ALT. }\end{array}$ \\
\hline
\end{tabular}


Table 1. Cont

\begin{tabular}{|c|c|c|c|c|c|}
\hline Treatment & Status & Sponsor & Phase and NCT & Clinical Outcomes & Adverse Events \\
\hline $\begin{array}{l}\text { Nivolumab administered } \\
\text { sequentially with } \\
\text { Ipilimumab in subjects with } \\
\text { advanced or metastatic } \\
\text { melanoma (CheckMate064) } \\
\text { [160] }\end{array}$ & $\begin{array}{l}\text { Active, } \\
\text { not } \\
\text { recruiting }\end{array}$ & BMS & II, NCT01783938 & $\begin{array}{l}\text { Nivolumab followed by ipilimumab was more clinically beneficial. } \\
\text { Nivolumab followed by Ipilimumab }(n=70) \text { : The median overall } \\
\text { survival was not reached. The } 1 \text { year overall survial was } 76 \%(95 \% \\
\text { CI: } 64-85 \%) \text {. The overall response rate, CR and PR was } 56 \%(95 \% \\
\text { CI: } 43.3-67 \%), 12 \% \text { and } 44 \% \text { respectively. } \\
\text { Ipilimumab followed by Nivolumab }(n=70) \text { : The median overall } \\
\text { survival was } 16.9 \text { months }(95 \% \text { CI: } 9.2-26.5 \text { months; HR: } 0.48 ; 95 \% \\
\text { CI for HR: } 0.29-0.8) \text {. The } 1 \text { year overall survival was } 54 \% \text { (95\% CI: } \\
\text { 42-65\%). The overall response rate, CR and PR was } 31 \% \text { ( } 95 \% \text { CI: } \\
\text { 20.9-43.6\%), } 6 \% \text { and } 26 \% \text { respectively. }\end{array}$ & $\begin{array}{l}\text { Pruiritus, rash, fatigue, chills, } \\
\text { pyrexia, vitiligo, diarrhoea, } \\
\text { nausea, increased ALT, AST } \\
\text { and lipase. }\end{array}$ \\
\hline
\end{tabular}




\section{AXL Inhibitors}

The TAM family of receptor tyrosine kinases (RTKs) is comprised of Tyro-3, Axl and Mer (TAM). These TAMS regulate cell proliferation, survival, adhesion, migration, invasion and metastasis of neoplasms [161]. The AXL gene is located on chromosome 19q13.2; encoded by 20 exons. The protein structure consists of an extracellular domain consisting of a combination of two IgG like domains and two fibronectin type III repeats; a conserved intracellular kinase domain and a transmembrane domain [162,163]. Even though all three TAMS have transforming potential, the aberrant overexpression of $\mathrm{Axl}$ is associated with cancer progression, drug resistance and supports tumor immune escape in several cancers including melanoma [164-172]. In primary and acquired resistance in melanoma, Axl levels inversely correlate with levels of melanocyte lineage factor- Microphthalmia-associated transcription factor (MITF). The high Axl, low MITF drug resistance phenotype is found frequently among BRAF mutant melanoma cell lines. This is associated with a phenotype switch of cells form proliferative to an invasive phenotype and promotes metastasis $[165,173,174]$. The Axl inhibitors can be classified into 2 types. Type I encompasses inhibitors that compete with ATP and bind to the active conformation of the receptor, DGF-in (constitutes of the aspartate-phenylalanine-glycine (DFG) motif oriented towards the active site). Type II inhibitors interact with the DFG residues of the activation loop which open up an allosteric region, adopt an extended conformation and prefer binding to the inactive DFG-out conformation. [175]

\subsection{BGB-324/Bemcentinib (Type I)}

This highly selective orally bioavailable inhibitor was developed by BerGenBio [176]. Upregulation of Axl leads to drug resistance of BRAF directed therapies in the context of melanoma and also reduces response to PD-1 blockade. A Phase Ib/II trial is ongoing (NCT02872259) evaluating BGB324 in combination with dabrafenib/tramatenib or pembrolizumab in advanced non-resectable Stage IIIc/IV melanoma. The interim results for this study indicate that the combination was well tolerated at the recommended phase 2 dose of $200 \mathrm{mg}$ daily of Bemcentinib. The common adverse events were diarrhea, fatigue, rash and pyrexia [177].

\subsection{TP-0903 (Type I)}

This oral Axl kinase inhibitor was developed by Tolero Pharmaceuticals, Inc. A first-in-human phase Ia/lb trial (NCT02729298) evaluating TP-0903 in patients with advanced solid tumors encompassing BRAF mutated melanoma patients who haven't responded to BRAF/MEK inhibitor combination or immunotherapy is currently recruiting patients [178,179].

\subsection{Cabozantinib/XL184/BMS-907351 (Type II)}

This inhibitor, developed by Exelixis [180], is an orally bioavailable small molecule inhibitor against various tyrosine kinases which include Axl, MET and VEGF. A phase II trial (NCT00940225) evaluating cabozantinib in patients with metastatic melanoma was discontinued as the study was underpowered to detect statistical significance [181]. A phase I/II trial (NCT03957551) evaluating the combination of cabozantinib and pembrolizumab as a front-line therapy has been initiated for patients with advanced metastatic melanoma [182].

\subsection{LDC1267 (Type II)}

This inhibitor preferentially inhibits Axl, Mer and Tyro3. In an in vivo model, it was observed that treatment with LDC1267 unleashes natural killer (NK) cells to target and kill tumor cells. Treatment with LDC1267 reduced the metastatic spreading of melanoma in an in vivo B16F10 melanoma model [183]. Further pre-clinical and clinical trials need to be initiated to test the efficacy of this drug in melanoma. 


\subsection{AXL-1047-MMAE}

This is an antibody-drug conjugate (ADC) in which the Axl targeting human antibody is conjugated to monomethyl auristatin $\mathrm{E}$ (MMAE), a microtubule disrupting agent by a valine citrulline linker which is protease-cleavable. This ADC induces cytotoxicity in vitro and in vivo in melanoma models. Treatment with the ADC prevents the emergence of BRAF-inhibitor resistant clones and potentiates the efficacy of BRAF and MEK inhibitors and co-operatively targets the growth of resistant cells. This ADC along with BRAF and MEK inhibitors has shown efficacy in treatment naïve and MAPK pathway inhibitor resistant melanoma. A phase I/II trial (NCT02988817) evaluating enapotamab vendotin (HuMax-AXL-ADC) has been initiated in patients with solid tumors, including melanoma $[184,185]$

\section{BRAF Inhibitors}

BRAF inhibitors are small molecule inhibitors that selectively target mutant BRAF isoforms, preferentially V600E but also other isoforms such as V600K or V600D [186]. BRAF inhibitors are typically used in combination with inhibitors of MEK, the downstream target of BRAF, in order to delay the development of resistance to BRAF inhibitor monotherapy as in the current standard of care for late-stage BRAF ${ }^{\mathrm{V} 600 \mathrm{E}}$ melanoma, dabrafenib and trametinib. Vemurafenib/PLX4032/RG7204, a serine/threonine kinase inhibitor, was the first selective BRAF inhibitor that was approved by the FDA. It binds to the ATP-binding domain of BRAF mutants such as V600E, V600R and V600D [187]. $960 \mathrm{mg}$ twice daily was established as the recommended phase 2 dose in the phase 1 (NCT00405587) dose escalation clinical trial [186]. The FDA approval was granted based on the Phase 3 trial (BRIM-3) results (NCT01006980) which exhibited improved overall survival and progression-free survival rate in patients with BRAFV600E mutant melanoma [188]. Dabrafenib, a type I-kinase inhibitor was the second BRAF inhibitor that was approved by the FDA. This reversible ATP-competitive inhibitor, inhibits BRAFV600E, V600D and V600K proteins [189]. The Phase 2 trial (BREAK-2; NCT01153763) trial established a dose of $150 \mathrm{mg}$ twice daily which can either be used as a single agent or in combination with trametinib [190,191]. It was granted FDA approval on the basis of the outcomes of Phase 3 trial (NCT01227889) in which it exhibited improved progression-free survival vs. decarbazine [24].

\section{Encorafenib/LGX818}

This molecule is an oral BRAF inhibitor selective for $\mathrm{BRAF}^{\mathrm{V} 600 \mathrm{E}}$ that was approved by the FDA in June 2018 for use in combination with the MEK inhibitor binimetinib (MEK162) in treating metastatic melanoma patients with the $\mathrm{BRAF}^{\mathrm{V} 600 \mathrm{E}}$ mutation [192]. A phase II trial (NCT02631447) to determine the optimal sequencing of BRAFi + MEKi (encorafenib + binimetinib) therapy and immunomodulatory antibody (ipilimumab + nivolumab) therapy in stage III-IV metastatic BRAF V600 melanoma is ongoing [193]. A phase II trial (NCT02159066) evaluating the use of third agent in encorafenib + binimetinib therapy in stage III-IV metastatic BRAF V600 melanoma [194].

\section{MEK Inhibitors}

MEK inhibitors are small molecule inhibitors targeting MEK1/2 proteins in the MAPK pathway. The addition of a MEK inhibitor in combination with a BRAF inhibitor delayed the development of resistance and decreased the toxicities associated with BRAF inhibitor monotherapy [195]. Trametinib/GSK1120212, a reversible, non-ATP-competitive inhibitor of MEK1/2 was the first MEK inhibitor approved by the FDA. The phase 1 study (NCT00687622) identified $2 \mathrm{mg}$ daily dose of trametinib, which could be safety, administered to the patients [196]. The phase 3 COMBI-D trial (NCT01584648) provided evidence of combining dabrafenib and trametinib in patients with metastatic BRAFV600E/K mutant melanoma as compared to monotherapy with dabrefenib [197]. Cobimetinib/GDC-0973 is used in combination with vemurafenib and is approved for patients with BRAFV600E/K mutant metastatic melanoma. The FDA approval was granted based on the efficacy results of combination of vemurafenib and cobimetinib in Phase-3 co-BRM trial (NCT01689519) [198]. 
Binimetinib/MEK162 is used in combination with encorafenib and is used in patients harbouring BRAFV600E/K mutation.

\section{1. $K Z-001$}

This selective MEK1/2 inhibitor is a benzoxazole compound with high potency and exhibits anti-tumor activity in BRAF- and NRAS-mutant tumor cell lines. It presented a synergistic effect in in vitro and in vivo xenograft models when used in combination with docetaxel (microtubule-stabilizing chemotherapeutic agent) and vemurafenib [199].

\section{2. $E 6201$}

This MEK1 inhibitor was developed by Eisai Inc. This ATP-competitive MEK inhibitor is a synthetic analog of a natural product f152A1 occuring from the fungus Curvularia verruculosa [200]. NCT00794781 was a Phase I trial, evaluating the efficacy and safety of E6201 in patients with BRAF mutant advanced melanoma was terminated early due to futility based on response data [201].

\subsection{TAK-733}

This selective, oral, potent, non-ATP competitive allosteric site MEK inhibitor was developed by Millenium Pharmaceuticals, Inc. It demonstrated anti-tumor effects in vitro in melanoma cell lines and in vivo in patients-derived xenograft models [202]. NCT00948467 was a Phase 1 dose escalation trial evaluating TAK-733 in advanced solid tumors including patients with advanced metastatic melanoma had manageable toxicity profile but had limited antitumor activity and based on this result the further investigations are not planned [203].

\subsection{PD-0325901/Mirdametinib}

This selective, potent, oral, noncompetitive MEK inhibitor was developed by Pfizer. It inhibited ERK phosphorylation in in vitro model. It inhibited growth of melanoma cell lines in vitro and in xenograft models. This molecule also inhibited angiogenesis by inhibiting VEGF production and induced apoptosis in in vitro models [204]. NCT00147550, a phase I/II clinical trial evaluating the efficacy of PD-0325901 in advanced melanoma has been terminated due to ocular, neurological and musculoskeletal toxicities at higher doses ( $>15 \mathrm{mg}$ twice a day) [205].

\section{ERK Inhibitors}

ERK plays a unique role in the MAPK/ERK pathway; it has more than 100 substrates, some of which are involved in MAPK/ERK activating/de-activating feedback loops, yet it has only one upstream effector, MEK1/2 [206]. Due to this role, ERK inhibitors may show promise as a method of overcoming the development of resistance and re-activation of BRAF and MEK in BRAF ${ }^{\mathrm{V} 600 \mathrm{E}}$ melanoma. While presently far behind BRAF and MEK inhibitors in development, there has been a recent increase in the development and evaluation of ERK inhibitors for treating $\mathrm{BRAF}^{\mathrm{V} 600 \mathrm{E}}$ melanoma.

\subsection{Ulixertinib/BVD-523}

Ulixertinib is a novel, selective ERK1/2 inhibitor developed by BioMed Valley Discoveries, that inhibits ERK1/2 in a reversible and competitive manner. Importantly, ulixertinib presented equivalent efficacy in BRAF mutant cells and BRAF + MEK double mutant cells, while the efficacy of BRAF and MEK inhibitors decreased in the double mutant line [207]. Currently, it has been designated for fast track status by the FDA in the treatment of metastatic BRAFV600E-mutant melanoma [208]. 


\section{2. $L Y 3214996$}

A selective ERK1/2 inhibitor developed by Eli Lilly currently in phase I clinical trials $[209,210]$. Further details of this pre-clinical characterization have not been made publicly available, and Phase I trials are on-going.

\section{3. $M K 8353$}

An orally dosed, selective inhibitor of activated ERK1/2, and non-activated ERK2 developed by Merck \& Co. currently recruiting for phase I trials [211,212]. A phase I clinical trial was initiated following these results in healthy volunteers (NCT01358331); however, the study was terminated after phase Ia MTD determination (400 mg orally once daily) for strategic reasons [213].

\section{4. $L T T 462$}

An oral ERK inhibitor developed by Novartis. LTT-462 has completed a phase I clinical trial for use in advanced cancers, including melanoma. A phase I clinical trial (NCT02711345) evaluating the use of LTT462 in advanced melanoma and other advanced cancer has concluded; however, the results are not yet publicly available [214].

\section{5. $\mathrm{KO}-947$}

A highly potent and selective ERK1/2 inhibitor developed by Kura Oncology [215].

\subsection{GDC0994}

An orally-dosed, selective ERK1/2 inhibitor developed by Genentech [216]. A phase Ia trial (NCT01875705) was conducted on MAPK-dysregulated cancers not including melanoma. The phase Ia trial found a safety profile consistent with MAPK inhibition with tolerable adverse events [217]. A following phase Ib trial (NCT02457793) investigating the use of GDC0994 in combination with cobimetinib (MEKi) in advanced cancers including advanced melanoma has completed; however, the comprehensive results have not yet been released [218].

\subsection{SCH772984}

This is a selective, ATP-competitive ERK inhibitor developed by Merck. It exhibits antitumor activity against BRAFV600E mutant and NRAS mutant melanoma. It blocks proliferation of melanoma cell lines in BRAF and MEK inhibitor resistant cell lines in vitro [219]. The synergistic combination of SCH772984 with Vemurafenib delayed the onset of acquired resistance in in vitro models [220]. Intermitent dosing with RAF inhibitor, MEK inhibitor and ERK inhibitor (SCH772984) inhibited tumor growth in low-level BRAF amplification patient derived xenograft model of melanoma [221].

Table 2 summarizes the clinical trials, outcomes and adverse effects of novel BRAF and ERK inhibitors that are under investigation in the clinic to treat metastatic melanoma patients [211,222-224]. 
Table 2. Summary of clinical trials, outcomes and adverse events associated with novel BRAF inhibitors and ERK inhibitors in patients with metastatic melanoma.

\begin{tabular}{|c|c|c|c|c|c|}
\hline Treatment & Status & Sponsor & Phase and NCT & Clinical Outcomes & Adverse Events \\
\hline \multicolumn{6}{|c|}{ BRAF inhibitors } \\
\hline $\begin{array}{l}\text { LGX818 in patients with } \\
\text { advanced or metastatic } \\
\text { BRAF mutant melanoma } \\
\text { [222] }\end{array}$ & $\begin{array}{l}\text { Active, not } \\
\text { recruiting }\end{array}$ & $\begin{array}{c}\text { Array } \\
\text { BioPharma }\end{array}$ & I, NCT01436656 & $\begin{array}{l}25 \text { BRAF-naïve and } 29 \text { BRAF inhibitor pretreated patients were enrolled in the study. } \\
\text { The treatment was tolerable up to the MTD of } 450 \mathrm{mg} \text { once daily, however the RP2D } \\
\text { was declared as } 300 \mathrm{mg} \text { once daily due to the increased risk of adverse events at } 450 \\
\text { mg. BRAFi-naive patients treated with } 300-450 \mathrm{mg} \text { once daily saw an RR of } 60 \% \text { and } \\
\text { PFS of } 12.4 \text { months ( } 95 \% \text { CI: 7.4-Not Reached), while for BRAFi-pretreated patients } \\
\text { the RR was } 22 \% \text { and the PFS was } 1.9 \text { months ( } 95 \% \text { CI: } 0.9-3.7 \text { months). }\end{array}$ & Nausea, myalgia, PPED \\
\hline $\begin{array}{l}\text { LGX818 in combination } \\
\text { with MEK162 in patients } \\
\text { with advanced solid } \\
\text { tumors } \\
\text { [223] }\end{array}$ & $\begin{array}{l}\text { Active, not } \\
\text { recruiting }\end{array}$ & $\begin{array}{c}\text { Array } \\
\text { BioPharma }\end{array}$ & $\begin{array}{c}\mathrm{Ib} / \mathrm{II} \\
\text { NCT01543698 }\end{array}$ & $\begin{array}{l}\text { The combination was safe with no substantial adverse evets observed. Nine BRAF } \\
\text { naïve and } 14 \text { BRAF inhibitor pretreated patients were enrolled. The MTD was unable } \\
\text { to be determined and the RP2D was } 450-600 \text { mg LGX818 }+45 \mathrm{mg} \text { MEK162 orally } \\
\text { once daily. CR and PR for BRAF-naïve patients were } 11 \% \text { and } 78 \% \text { respectively. The } \\
\text { PR for BRAF inhibitor pretreated patient groups was } 21 \% \text {. }\end{array}$ & $\begin{array}{l}\text { Nausea, abdominal pain, } \\
\text { headache, diarrhea, } \\
\text { fatigue, visual } \\
\text { impairment. }\end{array}$ \\
\hline $\begin{array}{c}\text { Encorafenib in } \\
\text { combination with } \\
\text { Binimetinib or } \\
\text { Vemurafenib in patients } \\
\text { with BRAF-mutant } \\
\text { melanoma (COLUMBUS) } \\
\text { [224] }\end{array}$ & $\begin{array}{l}\text { Active, not } \\
\text { recruiting }\end{array}$ & $\begin{array}{c}\text { Array } \\
\text { BioPharma }\end{array}$ & $\begin{array}{c}\text { III, } \\
\text { NCT01909453 }\end{array}$ & 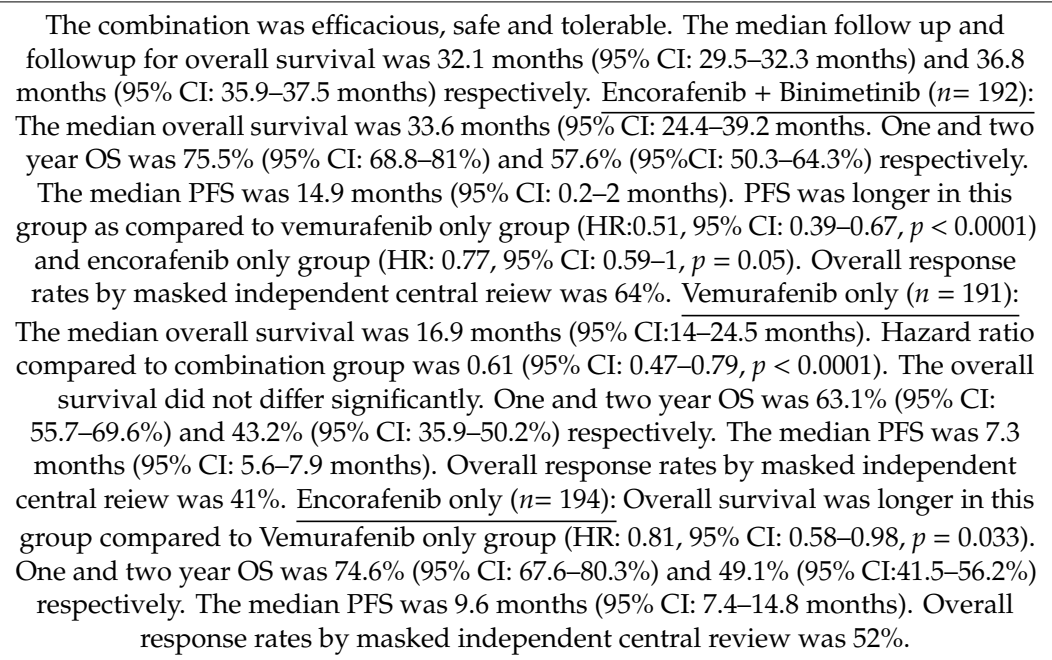 & $\begin{array}{c}\text { Palmar-plantar } \\
\text { erythrodysaesthesia, } \\
\text { nausea, diarrhea, } \\
\text { vomiting, fatigue, } \\
\text { myalgia, arthralgia, } \\
\text { increased } \\
\gamma \text {-glutamyltransferase, } \\
\text { increased blood creatine } \\
\text { phosphokinase, } \\
\text { hypertension }\end{array}$ \\
\hline \multicolumn{6}{|c|}{ ERK inhibitor } \\
\hline $\begin{array}{l}\text { Ulixertinib in patients } \\
\text { with advanced solid } \\
\text { tumors } \\
\text { [211] }\end{array}$ & Completed & $\begin{array}{l}\text { BioMed } \\
\text { Valley } \\
\text { Discoveries, } \\
\quad \text { Inc. }\end{array}$ & I, NCT01781429 & $\begin{array}{l}135 \text { patients were enrolled in the study. The treatment was well tolerated and had an } \\
\text { acceptable safety profile at doses of } 600 \mathrm{mg} \text { twice daily and this dose was established } \\
\text { as MTD and RP2D. This dose demonstrated anti-tumor activity in patients with } \\
\text { treatment naïve or those progressed on MAPK pathway inhibitors. The PR was } 12 \% \text {. }\end{array}$ & $\begin{array}{l}\text { Diarrhea, fatigue, } \\
\text { dehydration, nausea, rash, } \\
\text { dermatitis acneiform, } \\
\text { increased blood } \\
\text { creatinine. }\end{array}$ \\
\hline
\end{tabular}




\section{ROS Activated Prodrugs}

Redox homeostasis is essential for cell transcription, proliferation and survival. Failure of regulating redox homeostasis can cause DNA damage and cell apoptosis [225]. Cancer cells are known to express increased reactive oxygen species (ROS) such as superoxide, $\mathrm{H}_{2} \mathrm{O}_{2}$ and the hydroxyl radicals [226-229]. Evidence has shown a significant increase in ROS levels after B-RAF inhibition in melanoma cells [230]. ROS-activated prodrugs can be potentially utilized in combination with B-RAF inhibitors to target metastatic melanoma cells.

\subsection{Protein Ribonuclease A (RNase A)/SN-38}

These ROS activated drugs usually contain two separate functional domains- a ROS-accepting moiety, "Trigger", and an "Effector". In the presence of $\mathrm{H}_{2} \mathrm{O}_{2}$, the B-C bond within the aryl Byronic acid or esters will become oxidized, releasing the phenol group and activating the pro-drug. Protein ribonuclease A (RNase A) and SN-38 are being studied in the B16F10 murine melanoma cell line which mimics primary tumor growth [231,232]. SN-38 significantly decreases the proliferation of B16F10 murine melanoma cell line [231]. The enzymatic activity of RNase A will be reduced and cytotoxicity is improved when being activated via high ROS levels against skin melanoma cancer cells (B16F10) [232]. The success of these prodrugs in reducing tumor proliferation in murine melanoma cells gives the potential to study these drugs in human melanoma cell lines and potentially into clinical trials.

\subsection{A100/RAC1}

A100 is a quinone derivative. Quinones have substituents on the activated alkene, which are also called Michael acceptors. Cell damage and cytotoxicity occurs through the alkylation of DNA or cellular proteins. A100 sensitizes dabrafenib-resistant melanoma cells to BRAF protein kinase inhibitors [233]. A100, in the presence of high ROS levels, can self-cyclize into a bicyclic ring and cause DNA double strand breaks in cancer cells [234]. This compound and related ROS activated pro-drugs could be useful therapeutic agents where a BRAF inhibition has failed as the first line of treatment in melanoma patients harboring $\mathrm{BRAF}^{\mathrm{V} 600 \mathrm{E}}$ mutation.

\section{Conclusions}

Resistance to therapies continues to push the need to expand our understanding of melanoma treatment. This has led to exploring new treatments that utilizes combination therapies in order to achieve maximum anti-tumor efficacy over long durations of treatment avoiding resistance. Advances in the treatment of metastatic melanoma are on the rise with progress in targeted molecular therapy and immunotherapy. Targeted therapies are now expanding to include new BRAF and MEK inhibitors together and in combination with other therapies. Progress is being made in the field for targeting Axl and with ROS activated prodrugs. Immunotherapies are a new area of interest focusing on manipulation of checkpoint inhibition with durable clinical responses in patients. Melanoma has a strong molecular and genetic basis of pathogenicity, which allows for the development of personalized medicine. Selecting unique and individual treatments for melanoma patient makes it more likely to achieve high success rates in the clinic. Continual research and clinical trials are ongoing to further elucidate and expand knowledge on mechanisms of resistance and novel treatment strategies such as immunotherapies, new small molecule inhibitors and ROS-activated prodrugs to provide effective care to patients with metastatic melanoma.

Author Contributions: Conceptualization, H.P., J.T.G.; writing-original draft preparation, H.P., N.Y., R.M., A.W., L.Y.; writing-reviewing and editing, H.P., N.Y., R.M., S.A., J.T.G.; table preparation, H.P., R.M., A.W.; figure preparation, N.Y.; supervision, J.T.G.; revised manuscript, H.P., N.Y., J.T.G. All authors have read and agreed to the published version of the manuscript.

Funding: This work was supported by DOD CDMRP PRCRP Career Development W81XWH1910441.

Conflicts of Interest: The authors declare no conflict of interest. 


\section{References}

1. Miller, A.J.; Mihm, M.C., Jr. Melanoma. N. Engl. J. Med. 2006, 355, 51-65. [CrossRef] [PubMed]

2. American Cancer Society. Cancer Facts \& Figures. 2019. Available online: https: //www.cancer.org/content/dam/cancer-org/research/cancer-facts-and-statistics/annual-cancer-factsand-figures/2019/cancer-facts-and-figures-2019.pdf (accessed on 22 November 2019).

3. Dobry, A.S.; Zogg, C.K.; Hodi, F.S.; Smith, T.R.; Ott, P.A.; Iorgulescu, J.B. Management of metastatic melanoma: Improved survival in a national cohort following the approvals of checkpoint blockade immunotherapies and targeted therapies. Cancer Immunol. Immunother. 2018, 67, 1833-1844. [CrossRef] [PubMed]

4. Albertini, M.R. The age of enlightenment in melanoma immunotherapy. J. Immunother. Cancer 2018, 6, 80. [CrossRef] [PubMed]

5. ASCO Post. Long-Term Survival Outcomes with New Treatments for Advanced Melanoma: Questions Still in Need of Answers. Available online: https://www.ascopost.com/issues/october-25-2019/long-termsurvival-outcomes-with-new-treatments-for-advanced-melanoma/ (accessed on 30 January 2020).

6. Liu, Y.; Sheikh, M.S. Melanoma: Molecular pathogenesis and therapeutic management. Mol. Cell. Pharmacol. 2014, 6, 228.

7. Dhillon, A.S.; Hagan, S.; Rath, O.; Kolch, W. MAPK kinase signaling pathways in cancer. Oncogene 2007, 26, 3279-3290. [CrossRef]

8. Millet, A.; Martin, A.R.; Ronoco, C.; Rocchi, S.; Benhida, R. Metastatic: Insights into the evolution of the treatments and future challenges. Med. Res. Rev. 2017, 37, 98-148. [CrossRef]

9. Cheng, L.; Lopez-Beltran, A.; Massari, F.; MacLennan, G.T.; Montironi, R. Molecular testing for BRAF mutations to inform melanoma treatment decisions: A move toward precision medicine. Mod. Pathol. 2018, 31, 24-38. [CrossRef]

10. Kong, B.Y.; Carlino, M.S.; Menzies, A.M. Biology and treatment of BRAF mutant metastatic melanoma. Melanoma Manag. 2016, 3, 33-45. [CrossRef]

11. American Cancer Society. Treating Melanoma Skin Cancer. Available online: https://www.cancer.org/cancer/ melanoma-skin-cancer/treating.html (accessed on 22 November 2019).

12. Shirley, M. Encorafenib and Binimetinib: First global approvals. Drugs 2018, 78, 1277-1284. [CrossRef] [PubMed]

13. Eroglu, Z.; Ribas, A. Combination therapy with BRAF and MEK inhibitors for melanoma: Latest evidence and place in therapy. Ther. Adv. Med. Oncol. 2016, 8, 48-56. [CrossRef]

14. Marconcini, R.; Spagnolo, F.; Stucci, L.S.; Ribero, S.; Marra, E.; Rosa, F.; Picasso, V.; Di Gurado, L.; Cimminiello, C.; Cavalieri, S.; et al. Current status and perspective in immunotherapy for metastatic melanoma. Oncotarget 2018, 9, 12452-12470. [PubMed]

15. Ribas, A.; Lawrence, D.; Atkinson, V.; Agarwal, S.; Miller, W.H., Jr.; Carlino, M.S.; Fisher, R.; Long, G.V.; Hodi, F.S.; Tsoi, J.; et al. Combined BRAF and MEK inhibition with PD-1 blockade immunotherapy in BRAF-mutant melanoma. Nat. Med. 2019, 25, 936-940. [CrossRef] [PubMed]

16. Simeone, E.; Grimaldi, A.M.; Festino, L.; Vanella, V.; Palla, M.; Ascierto, P.A. Combination treatment of patients with BRAF-mutant melanoma: A new standard of care. BioDrugs 2017, 31, 51-61. [CrossRef] [PubMed]

17. Davies, M.A.; Kwong, L.N. Navigating the therapeutic complexity of PI3K pathway inhibition in melanoma. Clin. Cancer Res. 2013, 19, 5310-5319.

18. Harris, A.L.; Lee, S.E.; Dawson, L.K.; Marlow, L.A.; Edenfield, B.H.; Durham, W.F.; Flotte, T.J.; Thompson, M.; Small, D.L.; Synnott, A.J. Targeting the cyclin dependent kinase and retinoblastoma axis overcomes standard

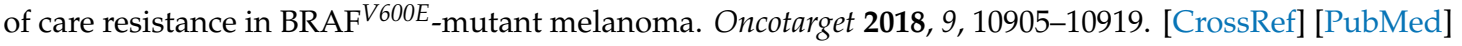

19. Aasen, S.N.; Parajuli, H.; Hoang, T.; Feng, Z.; Stokke, K.; Wang, J.; Roy, K.; Bjerkvig, R.; Knappskog, S.; Thorsen, F. Effective Treatment of Metastatic Melanoma by Combining MAPK and PI3K Signaling Pathway Inhibitors. Int. J. Mol. Sci. 2019, 20, 4235. [CrossRef] [PubMed]

20. Schettini, F.; Santo, I.D.; Rea, C.G.; Placido, P.D.; Formisano, L.; Giuliano, M.; Arpino, G.; Laurentiis, M.D.; Puglisi, F.; Placido, S.D.; et al. CDK 4/6 Inhibitors as Single Agent in Advanced Solid Tumors. Front Oncol. 2018, 8, 608. [CrossRef]

21. Kollmann, K.; Briand, C.; Bellutti, F.; Schicher, N.; Blunder, S.; Zojer, M.; Hoeller, C. The interplay of CDK4 and CDK6 in melanoma. Oncotarget 2019, 10, 1346-1359. [CrossRef] 
22. Lee, B.; McArthur, G.A. CDK4 inhibitors an emerging strategy for the treatment of melanoma. Melanoma Manag. 2015, 2, 255-266. [CrossRef]

23. Sosman, J.A.; Kim, K.B.; Schuchter, L.; Gonzalez, R.; Pavlick, A.C.; Weber, J.S.; McArthur, G.A.; Hutson, T.E.; Moschos, S.J.; Flaherty, K.T.; et al. Survival in BRAF V600-mutant advanced melanoma treated with vemurafenib. N. Engl. J. Med. 2012, 366, 707-714. [CrossRef]

24. Hauschild, A.; Grob, J.J.; Demidov, L.V.; Jouary, T.; Gutzmer, R.; Millward, M.; Rutkowski, P.; Blanik, C.U.; Miller, W.H., Jr.; Kaempgen, E.; et al. Dabrafenib in BRAF-mutated metastatic melanoma: A multicentre, open-label, phase 3 randomised controlled trial. Lancet 2012, 380, 358-365. [CrossRef]

25. Spagnolo, F.; Ghiorzo, P.; Orgiano, L.; Pastorino, L.; Picasso, V.; Tornari, E.; Ottaviano, V.; Queirolo, P. BRAF-mutant melanoma: Treatment approaches, resistance mechanisms, and diagnostic strategies. OncoTargets Ther. 2015, 8, 157-168. [CrossRef] [PubMed]

26. Manzano, J.L.; Layos, L.; Bugés, C.; Llanos Gil, M.; Vila, L.; Martínez-Balibrea, E.; Martínez-Cardús, A. Resistant mechanisms to BRAF inhibitors in melanoma. Ann. Transl. Med. 2016, 4, 237. [CrossRef] [PubMed]

27. Wu, H.; Goel, V.; Haluska, F.G. PTEN signaling pathways in melanoma. Oncogene 2003, 22, 3113-3122. [CrossRef] [PubMed]

28. Davies, M.A. The multi-faceted roles of the PI3K-AKT pathway in melanoma. J. Transl. Med. 2015, 13 (Suppl. 1), K1. [CrossRef]

29. LoPiccolo, J.; Blumenthal, G.M.; Bernstein, W.B.; Dennis, P.A. Targeting the PI3K/Akt/mTOR pathway: Effective combinations and clinical considerations. Drug. Resist. Updates 2008, 11, 32-50. [CrossRef]

30. Sullivan, R.J.; Flaherty, K.T. Resistance to BRAF-targeted therapy in melanoma. Eur. J. Cancer 2013, 49, 1297-1304. [CrossRef]

31. Sauter, E.R.; Yeo, U.C.; von Stemm, A.; Zhu, W.; Litwin, S.; Tichansky, D.S.; Pistritto, G.; Nesbit, M.; Pinkel, D.; Herlyn, M.; et al. Cyclin D1 is a candidate oncogene in cutaneous melanoma. Cancer Res. 2002, 62, 3200-3206.

32. Smalley, K.S.; Lioni, M.; Dalla Palma, M.; Xiao, M.; Desai, B.; Egyhazi, S.; Hansson, J.; Wu, H.; King, A.J.; Van Bella, P.; et al. Increased cyclin D1 expression can mediate BRAF inhibitor resistance in BRAF V600E-mutated melanomas. Mol. Cancer Ther. 2008, 7, 2876-2883. [CrossRef]

33. Nissan, M.H.; Pratilas, C.A.; Jones, A.M.; Ramirez, R.; Won, H.; Liu, C.; Tiwari, S.; Kong, L.; Hanrahan, A.J.; Yao, Z.; et al. Loss of NF1 in cutaneous melanoma is associated with RAS activation and MEK dependence. Cancer Res. 2014, 74, 2340-2350. [CrossRef]

34. Kiuru, M.; Busam, K.J. The NF1 gene in tumor syndromes and melanoma. Lab. Investig. 2017, 97, $146-157$. [CrossRef] [PubMed]

35. Watson, I.R.; Li, L.; Cabeceiras; Mahdavi, M.; Gutschner, T.; Genovese, G.; Wang, G.; Fang, Z.; Tepper, J.M.; Stemke-Hale, K.; et al. The RAC1 P29S hotspot mutation in melanoma confers resistance to pharmacological inhibition of RAF. Cancer Res. 2014, 74, 4845-4852. [CrossRef] [PubMed]

36. Wertheimer, E.; Gutierrez-Uzquiza, A.; Rosemblit, C.; Lopez-Haber, C.; Sosa, M.S.; Kazanietz, M.G. Rac signaling in breast cancer: A tale of GEFs and GAPs. Cell Signal. 2012, 24, 353-362. [CrossRef]

37. Hodis, E.; Watson, I.R.; Kryukov, G.V.; Arold, S.T.; Imielinski, M.; Theurillat, J.P.; Nickerson, E.; Auclair, D.; Li, L.; Place, C.; et al. A landscape of driver mutations in melanoma. Cell 2012, 150, 251-263. [CrossRef] [PubMed]

38. Carlino, M.S.; Fung, C.; Shahheydari, H.; Todd, J.R.; Boyd, S.C.; Irvine, M.; Nagrial, A.M.; Scolyer, R.A.; Kefford, R.F.; Long, G.V.; et al. Preexisting MEK1P124 mutations diminish response to BRAF inhibitors in metastatic melanoma patients. Clin. Cancer Res. 2015, 21, 98-105. [CrossRef] [PubMed]

39. Sun, C.; Wang, L.; Huang, S.; Heynen, G.J.; Prahallad, A.; Robert, C.; Haanen, J.; Blank, C.; Wesseling, J.; Willems, S.M.; et al. Reversible and adaptive resistance to BRAF(V600E) inhibition in melanoma. Nature 2014, 508, 118-122. [CrossRef] [PubMed]

40. Nazarian, R.; Shi, H.; Wang, Q.; Kong, X.; Koya, R.C.; Lee, H.; Chen, Z.; Lee, M.K.; Attar, N.; Sazegar, H.; et al. Melanomas acquire resistance to B-RAF(V600E) inhibition by RTK or N-RAS upregulation. Nature 2010, 468, 973-977. [CrossRef]

41. Villanueva, J.; Vultur, A.; Lee, J.T.; Somasundaram, R.; Fukunaga-Kalabis, M.; Cipolla, A.K.; Wubbenhorst, B.; Xu, X.; Gimotty, P.A.; Kee, D.; et al. Acquired resistance to BRAF inhibitors mediated by a RAF kinase switch in melanoma can be overcome by cotargeting MEK and IGF-1R/PI3K. Cancer Cell 2010, 18, 683-695. [CrossRef] 
42. Wang, J.; Huang, S.K.; Marzese, D.M.; Hsu, S.C.; Kawas, N.P.; Chong, K.K.; Long, G.V.; Menzies, A.M.; Scolyer, R.A.; Izraely, S.; et al. Epigenetic changes of EGFR have an important role in BRAF inhibitor-resistant cutaneous melanomas. J. Investig. Dermatol. 2015, 135, 532-541. [CrossRef]

43. Muñoz-Couselo, E.; Zamora Adelantado, E.; Ortiz, C.; Soberino García, J.; Perez-Garcia, J. NRAS-mutant melanoma: Current challenges and future prospect. OncoTargets Ther. 2017, 10, 3941-3947.

44. Malumbres, M.; Barbacid, M. RAS oncogenes: The first 30 years. Nat. Rev. Cancer 2003, 3, 459-465. [CrossRef] [PubMed]

45. Heidorn, S.J.; Milagre, C.; Whittaker, S.; Nourry, A.; Niculescu-Duvas, I.; Dhomen, N.; Hussain, J.; ReisFilho, J.S.; Springer, C.J.; Pritchard, C.; et al. Kinase-dead BRAF and oncogenic RAS cooperate to drive tumor progression through CRAF. Cell 2010, 140, 209-221. [CrossRef] [PubMed]

46. Oh, Y.T.; Deng, J.; Yue, P.; Sun, S.Y. Paradoxical activation of MEK/ERK signaling induced by B-Raf inhibition enhances DR5 expression and DR5 activation-induced apoptosis in Ras-mutant cancer cells. Sci. Rep. 2016, 6, 26803. [CrossRef] [PubMed]

47. Poulikakos, P.I.; Zhang, C.; Bollag, G.; Shokat, K.M.; Rosen, N. RAF inhibitors transactivate RAF dimers and ERK signalling in cells with wild-type BRAF. Nature 2010, 464, 427-430. [CrossRef] [PubMed]

48. Poulikakos, P.I.; Persaud, Y.; Janakiraman, M.; Kong, X.; Ng, C.; Moriceau, G.; Shi, H.; Atefi, M.; Titz, B.; Gabay, M.T; et al. RAF inhibitor resistance is mediated by dimerization of aberrantly spliced BRAF(V600E). Nature 2011, 480, 387-390. [CrossRef] [PubMed]

49. Shi, H.; Moriceau, G.; Kong, X.; Lee, M.K.; Lee, H.; Koya, R.C.; Ng, C.; Chodon, T.; Scolyer, R.A.; Dahlman, K.B.; et al. Melanoma whole-exome sequencing identifies V600EB-RAF amplification-mediated acquired B-RAF inhibitor resistance. Nat. Commun. 2012, 3, 724. [CrossRef]

50. Montagut, C.; Sharma, S.V.; Shioda, T.; McDermott, U.; Ulman, M.; Ulkus, L.E.; Dias-Santagata, D.; Stubbs, H.; Lee, D.Y.; Singh, A.; et al. Elevated CRAF as a potential mechanism of acquired resistance to BRAF inhibition in melanoma. Cancer Res. 2008, 68, 4853-4861. [CrossRef]

51. Poulikakos, P.; Rosen, N. Mutant BRAF melanomas-dependence and resistance. Cancer Cell 2011, 19, 11-15. [CrossRef]

52. Straussman, R.; Morikawa, T.; Shee, K.; Barzily-Rokni, M.; Qian, Z.R.; Du, J.; Davis, A.; Mongare, M.M.; Gould, J.; Frederick, D.T.; et al. Tumour micro-environment elicits innate resistance to RAF inhibitors through HGF secretion. Nature 2012, 487, 500-504. [CrossRef]

53. Van Allen, E.M.; Wagle, N.; Sucker, A.; Treacy, D.J.; Johannessen, C.M.; Goetz, E.M.; Place, C.S.; Taylor-Weiner, A.; Whittaker, S.; Kryukov, G.V.; et al. The genetic landscape of clinical resistance to RAF inhibition in metastatic melanoma. Cancer Discov. 2014, 4, 94-109. [CrossRef]

54. Emery, C.M.; Vijayendran, K.G.; Zipser, M.C.; Sawyer, A.M.; Niu, L.; Kim, J.J.; Hatton, C.; Chopra, R.; Oberholzer, P.A.; Karpova, M.B.; et al. MEK1 mutations confer resistance to MEK and B-RAF inhibiton. Proc. Natl. Acad. Sci. USA. 2009, 106, 20411-20416. [CrossRef] [PubMed]

55. Nikolaev, S.I.; Rimoldi, D.; Iseli, C.; Valsesia, A.; Robyr, D.; Gehrig, C.; Harshman, K.; Guipponi, M.; Bukach, O.; Zoete, V. Exome sequencing identifies recurrent somatic MAP2K1 and MAP2K2 mutations in melanoma. Nat. Genet. 2011, 44, 133-139. [CrossRef] [PubMed]

56. Trunzer, K.; Pavlick, A.C.; Schuchter, L.; Gonzalez, R.; McArthur, G.A.; Hutson, T.E.; Moschos, S.J.; Flaherty, K.T.; Kim, K.B.; Weber, J.S.; et al. Pharmacodynamic effects and mechanisms of resistance to vemurafenib in patients with metastatic melanoma. J. Clin. Oncol. 2013, 31, 1767-1774. [CrossRef] [PubMed]

57. Little, A.S.; Balmanno, K.; Sale, M.J.; Newman, S.; Dry, J.R.; Hampson, M.; Edwards, P.A.W.; Smith, P.D.; Cook, S.J. A correction to the Research Article titled: Amplification of the driving oncogene, KRAS or BRAF, underpins acquired resistance to MEK1/2 inhibitors in colorectal cancer cells. Sci. Signal. 2011, 4, er2. [CrossRef]

58. Tirosh, I.; Izar, B.; Prakadan, S.M.; Wadsworth, M.H.; Treacy, D.; Trombetta, J.J.; Rotem, A.; Rodman, C.; Lian, C.; Murphy, G.; et al. Dissecting the multicellular ecosystem of metastatic melanoma by single-cell RNA-seq. Science 2016, 352, 189-196. [CrossRef]

59. Hugo, W.; Shi, H.; Sun, L.; Piva, M.; Song, C.; Kong, X.; Moriceau, G.; Hong, A.; Dahlman, K.B.; Johnson, D.B.; et al. Non-genomic and immune evolution of melanoma acquiring MAPKi resistance. Cell 2015, 162, 1271-1285. [CrossRef] 
60. Wagle, N.; Van Allen, E.M.; Treacy, D.J.; Frederick, D.T.; Cooper, Z.A.; Taylor-Weiner, A.; Rosenberg, M.; Goetz, E.M.; Sullivan, R.J.; Farlow, D.N.; et al. MAP kinase pathway alterations in BRAF-mutant melanoma patients with acquired resistance to combined RAF/MEK inhibition. Cancer Discov. 2014, 4, 61-68. [CrossRef]

61. Moriceau, G.; Hugo, W.; Hong, A.; Shi, H.; Kong, X.; Yu, C.C.; Koya, R.C.; Samatar, A.A.; Khanlou, N.; Braun, J.; et al. Tunable-combinatorial mechanisms of acquired resistance limit the efficacy of BRAF/MEK cotargeting but result in melanoma drug addiction. Cancer Cell 2015, 27, 240-256. [CrossRef]

62. Long, G.V.; Fung, C.; Menzies, A.M.; Pupo, G.M.; Carlino, M.S.; Hyman, J.; Shahheydari, H.; Tembe, V.; Thompson, J.F.; Saw, R.P.; et al. Increased MAPK reactivation in early resistance to dabrafenib/trametinib combination therapy of BRAF-mutant metastatic melanoma. Nat. Commun. 2014, 5, 5694. [CrossRef]

63. Seidel, J.A.; Otsuka, A.; Kabashima, K. Anti-PD-1 and Anti-CTLA-4 Therapies in Cancer: Mechanisms of Action, Efficacy, and Limitations. Front. Oncol. 2018, 8, 86. [CrossRef]

64. Pieper, N.; Zaremba, A.; Leonardelli, S.; Harbers, F.N.; Schwamborn, M.; Lübcke, S.; Schrörs, B.; Baingo, J.; Schramm, A.; Haferkamp, S.; et al. Evolution of melanoma cross-resistance to $\mathrm{CD}^{+} \mathrm{T}$ cells and MAPK inhibition in the course of BRAFi treatment. Oncoimmunology 2018, 7, e1450127. [CrossRef] [PubMed]

65. Jiang, X.; Zhou, J.; Giobbie-Hurder, A.; Wargo, J.; Hodi, F.S. The activation of MAPK in melanoma cells resistant to BRAF inhibition promotes PD-L1 expression that is reversible by MEK and PI3K inhibition. Clin. Cancer Res. 2013, 19, 598-609. [CrossRef] [PubMed]

66. Ascierto, P.A.; Dummer, R. Immunological effects of BRAF+MEK inhibition. Oncoimmunology 2018, 7, e1468955. [CrossRef] [PubMed]

67. Ackerman, A.; Klein, O.; McDermott, D.F.; Wang, W.; Ibrahim, N.; Lawrence, D.P.; Gunturi, A.; Flaherty, K.T.; Hodi, F.S.; Kefford, R.; et al. Outcomes of patients with metastatic melanoma treated with immunotherapy prior to or after BRAF inhibitors. Cancer 2014, 120, 1695-1701. [CrossRef]

68. Johnson, D.B.; Pectasides, E.; Feld, E.; Ye, F.; Zhao, S.; Johnpulle, R.; Merritt, R.; McDermott, D.F.; Puzanov, I.; Lawrence, D.; et al. Sequencing treatment in BRAFV600 mutant melanoma: Anti-pd-1 before and after BRAF inhibition. J. Immunother. 2017, 40, 31-35. [CrossRef]

69. Tétu, P.; Mangana, J.; Dummer, R.; Dutriaux, C.; Beneton, N.; Dalle, S.; Meyer, N.; Oriano, B.; Michielin, O.; Lebbe, C. Benefit of the nivolumab and ipilimumab combination in pretreated advanced melanoma. Eur. J. Cancer 2018, 93, 147-149. [CrossRef]

70. Jenkins, R.W.; Barbie, D.A.; Flaherty, K.T. Mechanisms of resistance to immune checkpoint inhibitors. Br. J. Cancer 2018, 118, 9-16. [CrossRef]

71. Pitt, J.M.; Vetizou, M.; Daillere, R.; Roberti, M.P.; Yamazaki, T.; Routy, B.; Lepage, P.; Boneca, I.G.; Chamaillard, M.; Kroemer, G.; et al. Resistance mechanisms to immune-checkpoint blockade in cancer: Tumor-intrinsic and -extrinsic factors. Immunity 2016, 44, 1255-1269. [CrossRef]

72. O'Donnell, J.S.; Long, G.V.; Scolyer, R.A.; Teng, M.W.; Smyth, M.J. Resistance to PD1/PDL1 checkpoint inhibition. Cancer Treat. Rev. 2017, 52, 71-81. [CrossRef]

73. Ott, P.A.; Hu, Z.; Keskin, D.B.; Shukla, S.A.; Sun, J.; Bozym, D.J.; Zhang, W.; Luoma, A.; Giobbie-Hurder, A.; Peter, L.; et al. An immunogenic personal neoantigen vaccine for patients with melanoma. Nature 2017, 547, 217-221. [CrossRef]

74. ASCO Post. Early Data Suggest TLR9 Agonist May Combat PD-1 Resistance in Advanced Melanoma. Available online: https:/www.ascopost.com/issues/july-10-2018/tlr9-agonist-may-combat-pd1-resistance-inadvanced-melanoma/ (accessed on 30 January 2020).

75. Warming "cold" melanoma with TLR9 agonists. Cancer Disocv. 2018, 8, 670. [CrossRef] [PubMed]

76. Bayan, C.Y.; Lopez, A.T.; Gartrell, R.D.; Komatsubara, K.M.; Bogardus, M.; Rao, N.; Chen, C.; Hart, T.D.; Enzler, T.; Rizk, E.M.; et al. The role of oncolytic viruses in the treatment of melanoma. Curr. Oncol. Rep. 2018, 20, 80. [CrossRef] [PubMed]

77. Rothermel, L.D.; Zager, J.S. Engineered oncolytic viruses to treat melanoma: Where are we now and what comes next? Expert Opin. Biol. Ther. 2018, 18, 1199-1207. [CrossRef] [PubMed]

78. Alsaab, H.O.; Sau, S.; Alzhrani, R.; Tatiparti, K.; Bhise, K.; Kashaw, S.K.; Iyer, A.K. PD-1 and PD-L1 checkpoint signaling inhibition for cancer immunotherapy: Mechanism, combinations, and clinical outcome. Front. Pharmacol. 2017, 8, 561. [CrossRef]

79. U.S. FDA. Available online: https://www.accessdata.fda.gov/drugsatfda_docs/label/2017/125514s014lbl.pdf (accessed on 25 November 2019). 
80. Sundar, R.; Cho, B.C.; Brahmer, J.R.; Soo, R.A. Nivolumab in NSCLC: Latest evidence and clinical potential. Ther. Adv. Med. Oncol. 2015, 7, 85-96. [CrossRef]

81. Opdivo (Nivolumab). Available online: https://www.opdivo.com/ (accessed on 25 November 2019).

82. U.S. FDA. Available online: https://www.fda.gov/drugs/resources-information-approved-drugs/fda-grantsregular-approval-nivolumab-adjuvant-treatment-melanoma (accessed on 25 November 2019).

83. Pfizer. Available online: https://pfe-pfizercom-prod.s3.amazonaws.com/news/asco/Merck-PfizerAlliance_ AvelumabFactSheet_19May2015US.pdf (accessed on 25 November 2019).

84. Hamid, O.; Robert, C.; Daud, A.; Hodi, F.S.; Hwu, W.J.; Kefford, R.; Wolchok, J.D.; Hersey, P.; Joseph, R.W.; Weber, J.S. Safety and tumor responses with labrolizumab (Anti-PD-1) in melanoma. N. Engl. J. Med. 2013, 369, 134-144. [CrossRef]

85. Clinical Trials.gov. Avelumab in metastatic or locally advanced solid tumors (javelin solid tumor) (NCT01772004). Available online: https://clinicaltrials.gov/ct2/show/NCT01772004 (accessed on 25 November 2019).

86. U.S. FDA. Available online: https://www.fda.gov/drugs/resources-information-approved-drugs/durvalumabimfinzi (accessed on 25 November 2019).

87. WHO Drug Information. Available online: https://www.who.int/medicines/publications/druginformation/ innlists/PL112.pdf (accessed on 25 November 2019).

88. Clinical trials.gov. A study to assess the safety, tolerability and anti-tumour activity of ascending doses of selumetinib in combination with MEDI4736 and selumetinib in combination with MEDI4736 and tremelimumab in patients with advanced solid tumours (NCT02586987). Available online: https://clinicaltrials. gov/ct2/show/NCT02586987 (accessed on 25 November 2019).

89. STAT. Roche scores first U.S. approval of immunotherapy for breast cancer. Available online: https://www. statnews.com/2019/03/08/roche-tecentriq-first-breast-cancer-immunotherapy/ (accessed on 18 February 2020).

90. Genetech. Tecentriq (Atezolizumab). Available online: https://www.tecentriq.com/sclc.html?c=pdl16d97f8fb9c\&gclid=Cj0KCQiAiNnuBRD3ARIsAM8KmlutqqUW05ZgdukIzhafsOMh1gAH4qyuc5Ciohb_ 1847xGc9Aew3ESsaAptpEALw_wcB\&gclsrc=aw.ds (accessed on 25 November 2019).

91. Clinical trials.gov. Neoadjuvant Vemurafenib + Cobimetinib + Atezolizumab in melanoma: NEO-VC (NEO-VC) (NCT02303951). Available online: https://clinicaltrials.gov/ct2/show/NCT02303951 (accessed on 25 November 2019).

92. Clinical trials.gov. A Study of atezolizumab plus cobimetinib and vemurafenib versus placebo plus cobimetinib and vemurafenib in previously untreated BRAFv600 mutation-positive patients with metastatic or unresectable locally advanced melanoma (NCT02908672). Available online: https://clinicaltrials.gov/ct2/ show/NCT02908672 (accessed on 25 November 2019).

93. National Cancer Institute. Spratalizumab. Available online: https:/www.cancer.gov/publications/ dictionaries/cancer-drug/def/spartalizumab (accessed on 27 January 2020).

94. Clinical trials.gov. Study of safety and efficacy of DKY709 alone or in combination with PDR001 in patients with advanced solid tumors (NCT03891953). Available online: https://clinicaltrials.gov/ct2/show/ NCT03891953?term=Spartalizumab\&recrs=ae\&cond=melanoma\&draw=2\&rank=3 (accessed on 27 January 2020).

95. Clinical trials.gov. Study of efficacy and safety of novel spartalizumab combinations in patients with previously treated unresectable or metastatic melanoma (PLATforM) (NCT03484923). Available online: https:/clinicaltrials.gov/ct2/show/NCT03484923?term=Spartalizumab\&recrs=ae\&cond=melanoma\& draw=2\&rank=1 (accessed on 27 January 2020).

96. Clinical trials.gov. A study of the anti-PD1 antibody PDR001, in combination with dabrafenib and trametinib in advanced melanoma (COMBI-i) (NCT02967692). Available online: https:/clinicaltrials.gov/ct2/show/ NCT02967692?term=Spartalizumab\&recrs=ae\&cond=melanoma\&draw=2\&rank=2 (accessed on 27 January 2020).

97. Rowshanravan, B.; Halliday, N.; Sansom, D. CTLA-4: A moving target in immunotherapy. Blood 2018, 131, 58-67. [CrossRef]

98. Stamper, C.C.; Zhang, Y.; Tobin, J.F.; Erbe, D.V.; Ikemizu, S.; Davis, S.J.; Stahl, M.L.; Seehra, J.; Somers, W.S.; Mosyak, L. Crystal structure of the B7-1/CTLA-4 complex that inhibits human immune responses. Nature 2001, 410, 608-611. [CrossRef] 
99. Qureshi, O.S.; Zheng, Y.; Nakamura, K.; Attridge, K.; Manzotti, C.; Schmidt, E.M.; Baker, J.; Jeffery, L.E.; Kaur, S.; Briggs, Z. Trans-endocytosis of CD80 and CD86: A molecular basis for the cell-extrinsic function of CTLA-4. Science 2011, 332, 600-603. [CrossRef]

100. Esensten, J.H.; Helou, Y.A.; Chopra, G.; Weiss, A.; Bluestone, J.A. CD28 costimulation: From mechanism to therapy. Immunity 2016, 44, 973-988. [CrossRef]

101. Chan, D.V.; Gibson, H.M.; Aufiero, B.M.; Wilson, A.J.; Hafner, M.S.; Mi, Q.S.; Wong, H.K. Differential CTLA-4 expression in human CD4+ versus CD8+ T cells is associated with increased NFAT1 and inhibition of CD4+ proliferation. Genes Immunity 2014, 15, 25-32. [CrossRef] [PubMed]

102. Comin-Anduix, B.; Escuin-Ordinas, H.; Ibarrondo, F.J. Tremelimumab: Research and clinical development. OncoTargets Ther. 2016, 9, 1767-1776. [PubMed]

103. Clinical trials.gov. Phase I clinical trial of Tremelimumab plus MEDI3617 in patients with unresectable stage III or stage IV melanoma (NCT02141542). Available online: https://clinicaltrials.gov/ct2/show/NCT02141542? term $=$ nct02141542\&rank $=1$ (accessed on 26 November 2019).

104. Clinical trials.gov. Tremelimumab and CP-870,893 in patients with metastatic melanoma (NCT01103635). Available online: https:/clinicaltrials.gov/ct2/show/NCT01103635?term=nct01103635\&rank=1 (accessed on 26 November 2019).

105. Wolchok, J.D.; Hodi, F.S.; Weber, J.S.; Allison, J.P.; Urba, W.J.; Robert, C.; O’Day, S.J.; Humphrey, R.; Berman, D.M.; Lonberg, N.; et al. Development of ipilimumab: A novel immunotherapeutic approach for the treatment of advanced melanoma. Ann. N. Y. Acad. Sci. 2013, 1291, 1-13. [CrossRef] [PubMed]

106. Clinical trials.gov. Trial of neoadjuvant ipilimumab followed by melphalan via isolated limb infusion for patients with unresectable in-transit extremity melanoma (NCT02115243). Available online: https: //clinicaltrials.gov/ct2/show/NCT02115243?term=02115243\&rank=1 (accessed on 26 November 2019).

107. Clinical trials.gov. Galectin inhibitor (GR-MD-02) and Ipilimumab in patients with metastatic melanoma (NCT02117362). Available online: https:/clinicaltrials.gov/ct2/show/NCT02117362?term=02117362\&rank=1 (accessed on 26 November 2019).

108. Clinical trials.gov. A Study of combination with TBI-1401(HF10) and Ipilimumab in Japanese patients with unresectable or metastatic melanoma (NCT03153085). Available online: https://clinicaltrials.gov/ct2/show/ NCT03153085?term $=03153085 \&$ rank=1 (accessed on 26 November 2019).

109. Clinical trials.gov. Phase II trial of stereotactic body radiotherapy followed by Ipilimumab in treating patients with stage IV melanoma (NCT01970527). Available online: https://clinicaltrials.gov/ct2/show/NCT01970527? term $=01970527 \&$ rank $=1$ (accessed on 26 November 2019).

110. Yano, H.; Andrews, L.P.; Workman, C.J.; Vignali, D.A.A. Intratumoral regulatory T cells: Markers, subsets and their impact on anti-tumor immunity. Immunology 2019, 157, 232-247. [CrossRef]

111. Clinical trials.gov. Phase I study of BCD-145 (anti-CTLA-4) in patients with unresectable/metastatic melanoma (NCT03472027). Available online: https://clinicaltrials.gov/ct2/show/NCT03472027?term=NCT03472027\& rank=1 (accessed on 26 November 2019).

112. Clinical trials.gov. Selective HDAC6 inhibitor ACY-241 in combination with Ipilimumab and Nivolumab (NCT02935790). Available online: https:/clinicaltrials.gov/ct2/show/NCT02935790?term=02935790\&rank=1 (accessed on 26 November 2019).

113. Yamazaki, N.; Takenouchi, T.; Fujimoto, M.; Ihn, H.; Uchi, H.; Inozume, T.; Kiyohara, Y.; Uhara, H.; Nakagawa, K.; Furukawa, H.; et al. Phase 1b study of pembrolizumab (MK-3475; anti-PD-1 monoclonal antibody) in japanese patients with advanced melanoma (KEYNOTE-041). Cancer Chemother. Pharmacol. 2017, 79, 651-660. [CrossRef]

114. Ribas, A.; Puzanov, I.; Dummer, R.; Schadendorf, D.; Hamid, O.; Robert, C.; Hodi, F.S.; Schachter, J.; Pavlick, A.C.; Lewis, K.D.; et al. Pembrolizumab versus investigator-choice chemotherapy for ipilimumab-refractory melanoma (KEYNOTE-002): A randomised, controlled, phase 2 trial. Lancet Oncol. 2015, 16, 908-918. [CrossRef]

115. Robert, C.; Ribas, A.; Schachter, J.; Arance, A.; Grob, J.; Mortier, L.; Daud, A.; Carlino, M.; Mc Neil, C.M.; Lotem, M.; et al. Pembrolizumab versus ipilimumab in advanced melanoma (KEYNOTE-006): Post-hoc 5-year results from an open-label, multicentre, randomised, controlled, phase 3 study. Lancet Oncol. 2019, 20, 1239-1251. [CrossRef] 
116. Ribas, A.; Butler, M.; Lutzky, J.; Lawrence, D.P.; Robert, C.; MillerGerald, W.; Linette, P.; Ascierto, P.A.; Kuzel, T.; Algazi, A.P.; et al. Phase I study combining anti-PD-L1 (MEDI4736) with BRAF (dabrafenib) and/or MEK (trametinib) inhibitors in advanced melanoma. J. Clin. Oncol. 2015, 33, 3003. [CrossRef]

117. Topalian, S.L.; Hodi, F.S.; Brahmer, J.R.; Gettinger, S.N.; Smith, D.C.; McDermott, D.F.; Powderly, J.D.; Sosman, J.A.; Atkins, M.B.; Leming, P.D.; et al. Five-year survival and correlates among patients with advanced melanoma, renal cell carcinoma, or non-small cell lung cancer treated with Nivolumab. JAMA Oncol. 2019, 5, 1411-1420. [CrossRef]

118. Sullivan, R.J.; Hamid, O.; Gonzalez, R.; Infante, J.R.; Patel, M.R.; Hodi, F.S.; Lewis, K.D.; Tawbi, H.A.; Hernandez, G.; Wongchenko, M.J.; et al. Atezolizumab plus cobimetinib and vemurafenib in BRAF-mutated melanoma patients. Nat. Med. 2019, 25, 929-935. [CrossRef]

119. Kirkwood, J.M.; Lorigan, P.; Hersey, P.; Hauschild, A.; Robert, C.; McDermott, D.; Marshall, M.A.; Gomez-Navarro, J.; Liang, J.Q.; Bulanhagui, C.A. Phase II trial of tremelimumab (CP-675,206) in patients with advanced refractory or relapsed melanoma. Clin. Cancer Res. 2010, 16, 1042-1048. [CrossRef] [PubMed]

120. Weber, J.; Hamid, O.; Amin, A.; O’Day, S.; Masson, E.; Goldberg, S.M.; Williams, D.; Parker, S.M.; Chasalow, S.D.; Alaparthy, S.; et al. Randomized phase I pharmacokinetic study of ipilimumab with or without one of two different chemotherapy regimens in patients with untreated advanced melanoma. Cancer Immun. 2013, 13, 7. [PubMed]

121. Reilley, M.J.; Bailey, A.; Subbiah, V.; Janku, F.; Naing, A.; Falchook, G.; Karp, D.; Piha-Paul, S.; Tsimberidou, A.; Fu, S.; et al. Phase I clinical trial of combination imatinib and ipilimumab in patients with advanced malignancies. J. Immunother. Cancer 2017, 5, 35. [CrossRef] [PubMed]

122. Tarhini, A.; Lin, Y.; Lin, H.; Rahman, Z.; Vallabhaneni, P.; Mendiratta, P.; Pingpank, J.F.; Holtzman, M.P.; Yusko, E.C.; Rytlewski, J.A.; et al. Neoadjuvant ipilimumab (3 mg/kg or $10 \mathrm{mg} / \mathrm{kg}$ ) and high dose IFN- $\alpha 2 \mathrm{~b}$ in locally/regionally advanced melanoma: Safety, efficacy and impact on T-cell repertoire. J. Immunother. Cancer 2018, 6, 112. [CrossRef] [PubMed]

123. Brohl, A.S.; Khushalani, N.I.; Eroglu, Z.; Markowitz, J.; Thapa, R.; Chen, Y.A.; Kudchadkar, R.; Weber, J.S. A phase IB study of ipilimumab with peginterferon alfa-2b in patients with unresectable melanoma. $J$. Immunothr. Cancer 2016, 4, 85. [CrossRef]

124. Clinical trials.gov. A study of intratumoral injection of interlukin-2 and ipilimumab in patients with unresectable stages III-IV melanoma (NCT01672450). Available online: https:/clinicaltrials.gov/ct2/show/ NCT01672450?term $=01672450 \&$ rank=1 (accessed on 26 November 2019).

125. Ray, A.; Williams, M.A.; Meek, S.M.; Bowen, R.C.; Grossmann, K.F.; Andtbacka, R.H.; Bowles, T.L.; Hyngstrom, J.R.; Leachman, S.A.; Grossman, D.; et al. A phase I study of intratumoral ipilimumab and interleukin-2 in patients with advanced melanoma. Oncotarget 2016, 7, 64390-64399. [CrossRef]

126. Williams, N.L.; Wuthrick, E.J.; Kim, H.; Palmer, J.D.; Garg, S.; Eldredge-Hindy, H.; Daskalakis, C.; Feeney, K.J.; Mastrangelo, M.J.; Kim, L.J.; et al. Phase 1 study of Ipilimumab combined with whole brain radiation therapy or radiosurgery for melanoma patient with brain metastases. Int. J. Radiat. Oncol. Biol. Phys. 2017, 99, 22-30. [CrossRef]

127. Wolchok, J.D.; Neyns, B.; Linette, G.; Negrier, S.; Lutzky, J.; Thomas, L.; Waterfield, W.; Schadendorf, D.; Smylie, M.; Guthrie, T., Jr.; et al. Ipilimumab monotherapy in patients with pretreated advanced melanoma: A randomised, double-blind, multicentre, phase 2, dose-ranging study. Lancet Oncol. 2010, 11, 155-164. [CrossRef]

128. Di Giacomo, A.M.; Ascierto, P.A.; Queirolo, P.; Pilla, L.; Ridolfi, R.; Santinami, M.; Testori, A.; Simeone, E.; Guidoboni, M.; Maurichi, A.; et al. Three-year follow-up of advanced melanoma patients who received ipilimumab plus fotemustine in the italian network for tumor biotherapy (NIBIT)-M1 phase II study. Ann. Oncol. 2015, 26, 798-803. [CrossRef]

129. Haag, G.M.; Zoernig, I.; Hassel, J.C.; Halama, N.; Dick, J.; Lang, N.; Podola, L.; Funk, J.; Ziegelmeier, C.; Juenger, S.; et al. Phase II trial of ipilimumab in melanoma patients with preexisting humoural immune response to NY-ESO-1. Eur. J. Cancer 2018, 90, 122-129. [CrossRef]

130. Amin, A.; Lawson, D.H.; Salama, A.K.S.; Koon, H.B.; Guthrie, T., Jr.; Thomas, S.S.; O’Day, S.J.; Shaheen, M.F.; Zhang, B.; Francis, S.; et al. Phase II study of vemurafenib followed by ipilimumab in patients with previously untreated BRAF-mutated metastatic melanoma. J. Immunother. Cancer 2016, 4, 44. [CrossRef] [PubMed] 
131. Andtbacka, R.H.I.; Ross, M.I.; Agarwala, S.S.; Taylor, M.H.; Vetto, J.T.; Neves, R.I.; Daud, A.; Khong, H.T.; Ungerleider, R.S.; Tanaka, M. Efficacy and genetic analysis for a phase II multicenter trial of HF10, a replication-competent HSV-1 oncolytic immunotherapy, and ipilimumab combination treatment in patients with stage IIIb-IV unresectable or metastatic melanoma. J. Clin. Oncol. 2018, 36, 9541. [CrossRef]

132. Ariyan, C.E.; Lefkowitz, R.A.; Panageas, K.; Callahan, M.K.; Misholy, O.; Bello, D.; Fisher, C.; Kotin, A.; Siegelbaum, R.; Coit, D.G.; et al. Safety and clinical activity of combining systemic ipilimumab with isolated limb infusion in patients with in-transit melanoma. J. Clin. Oncol. 2014, 32, 9078. [CrossRef]

133. Yamazaki, N.; Kiyohara, Y.; Uhara, H.; Fukushima, S.; Uchi, H.; Shibagaki, N.; Tsutsumida, A.; Yoshikawa, S.; Okuyama, R.; Ito, Y.; et al. Phase II study of ipilimumab monotherapy in Japanese patients with advanced melanoma. Cancer Chemother. Pharmacol. 2015, 76, 997-1004. [CrossRef] [PubMed]

134. Clinical trials.gov. Ipilimumab+Temozolamide in metastatic melanoma (NCT01119508). Available online: https:/clinicaltrials.gov/ct2/show/NCT01119508?term=01119508\&rank=1 (accessed on 26 November 2019).

135. Patel, S.P.; Kim, D.W.; Bassett, R.L.; Cain, S.; Washington, E.; Hwu, W.J.; Kim, K.B.; Papadopoulos, N.E.; Homsi, J.; Hwu, P.; et al. A phase II study of ipilimumab plus temozolomide in patients with metastatic melanoma. Cancer Immunol. Immunother. 2017, 66, 1359-1366. [CrossRef] [PubMed]

136. Clinical trials.gov. A single arm study of Ipilimumab monotherapy in patients with previously treated unresectable stage III or IV melanoma (NCT00289627). Available online: https://clinicaltrials.gov/ct2/show/ NCT00289627?term=00289627\&rank=1 (accessed on 26 November 2019).

137. O’Day, S.J.; Maio, M.; Chiarion-Sileni, V.; Gajewski, T.F.; Pehamberger, H.; Bondarenko, I.N.; Queirolo, P.; Lundgren, L.; Mikhailov, S.; Roman, L.; et al. Efficacy and safety of ipilimumab monotherapy in patients with pretreated advanced melanoma: A multicenter single-arm phase II study. Ann. Oncol. 2010, 21, 1712-1717. [CrossRef] [PubMed]

138. Clinical trails.gov. Autologous TriMix-DC therapeutic vaccine in combination with Ipilimumab in patients with previously treated unresectable stage III or IV melanoma (TriMix-Ipi) (NCT01302496). Available online: https://clinicaltrials.gov/ct2/show/NCT01302496?term=01302496\&rank=1 (accessed on 26 November 2019).

139. Wilgenhof, S.; Corthals, J.; Heirman, C.; van Baren, N.; Lucas, S.; Kvistborg, P.; Thielemans, K.; Neyns, B. Phase II study of autologous monocyte-derived mRNA electroporated dendritic cells (TriMixDC-MEL) plus ipilimumab in patients with pretreated advanced melanoma. J. Clin. Oncol. 2016, 34, 1330-1338. [CrossRef]

140. Clinical trials.gov. GEM study: Radiation and Yervoy in patients with melanoma and brain metastatses (GRAY-B) (NCT02115139). Available online: https:/clinicaltrials.gov/ct2/show/NCT02115139?term= 02115139\&rank=1 (accessed on 26 November 2019).

141. Lopez-Martin, J.A.; Arance, A.M.; de la Cruz-Merino, L.; Illescas, A.; Valduvieco, I.; Berrocal, A.; Lopez Torrecila, J.; Marquez Rodas, I.; Garcia, M.; Soriano, V.; et al. Ipilimumab and radiation in patients with unresectable melanoma brain metastases: A multicenter, open label, phase-2, Spanish Melanoma Group (GEM) study (NCT-2013-001132-22). J. Clin. Oncol. 2018, 36, 9546. [CrossRef]

142. Mortier, L.; Jamme, P.; Lacour, J.P.; Robert, C.; Lesimple, T.; Thomas, L.; Machet, L.; Saiag, P.; Lebbe, C.; Dutriaux, C.; et al. Ipilimumab combined with stereotactic radiosurgery in melanoma patients with brain metastases: A multicenter, open label, phase 2 trial. J. Clin. Oncol. 2018, 36, 9520. [CrossRef]

143. Hersh, E.M.; O’Day, S.J.; Powderly, J.; Khan, K.D.; Pavlick, A.C.; Cranmer, L.D.; Samlowski, W.E.; Nichol, G.M.; Yellin, M.J.; Weber, J.S. A phase II multicenter study of ipilimumab with or without dacarbazine in chemotherapy-naïve patients with advanced melanoma. Investig. New Drugs 2011, 29, 489-498. [CrossRef]

144. Andtbacka, R.H.I.; Ross, M.I.; Agarwala, S.S.; Taylor, M.H.; Vetto, J.T.; Neves, R.I.; Daud, A.; Khong, H.T.; Ungerleider, R.S.; Tanaka, M.; et al. Final results of a phase II multicenter trial of HF10, a replication-competent HSV-1 oncolytic virus, and ipilimumab combination treatment in patients with stage IIIB-IV unresectable or metastatic melanoma. J. Clin. Oncol. 2017, 35, 9510. [CrossRef]

145. Maio, M.; Grob, J.J.; Aamdal, S.; Bondarenko, I.; Robert, C.; Thomas, L.; Garbe, C.; Chiarion-Sileni, V.; Testori, A.; Chen, T.T.; et al. Five-year survival rates for treatment-naive patients with advanced melanoma who received ipilimumab plus dacarbazine in a phase III trial. J. Clin. Oncol. 2015, 33, 1191-1196. [CrossRef] [PubMed]

146. McDermott, D.; Haanen, J.; Chen, T.T.; Lorigan, P.; O’Day, S. MDX010-20 Investigators. Efficacy and safety of ipilimumab in metastatic melanoma patients surviving more than 2 years following treatment in a phase III trial (MDX010-20). Ann. Oncol. 2013, 24, 2694-2698. [CrossRef] 
147. Ascierto, P.A.; Del Vecchio, M.; Robert, C.; Mackiewicz, A.; Chiarion-Sileni, V.; Arance, A.; Lebbé, C.; Bastholt, L.; Hamid, O.; Rutkowski, P.; et al. Ipilimumab $10 \mathrm{mg} / \mathrm{kg}$ versus ipilimumab $3 \mathrm{mg} / \mathrm{kg}$ in patients with unresectable or metastatic melanoma: A randomised, double-blind, multicentre, phase 3 trial. Lancet Oncol. 2017, 18, 611-622. [CrossRef]

148. Chesney, J.; Puzanov, I.; Collichio, F.; Singh, P.; Milhem, M.M.; Glaspy, J.; Hamid, O.; Ross, M.; Friedlander, P.; Garbe, C.; et al. Randomized, open-label phase II study evaluating the efficacy and safety of talimogene laherparepvec in combination with Ipilimumab versus Ipilimumab alone in patients with advanced, unresectable melanoma. J. Clin. Oncol. 2018, 36, 1658-1667. [CrossRef]

149. Hiniker, S.M.; Reddy, S.A.; Maecker, H.T.; Subrahmanyam, P.B.; Rosenberg-Hasson, Y.; Swetter, S.M.; Saha, S.; Shura, L.; Knox, S.J. A prospective clinical trial combining radiation therapy with systemic immunotherapy in metastatic melanoma. Int. J. Radiat. Oncol. Biol. Phys. 2016, 96, 578-588. [CrossRef]

150. Hodi, F.S.; Lee, S.; McDermott, D.F.; Rao, U.N.; Butterfield, L.H.; Tarhini, A.A.; Leming, P.; Puzanov, I.; Shin, D.; Kirkwood, J.M. Ipilimumab plus sargramostim vs ipilimumab alone for treatment of metastatic melanoma: A randomized clinical trial. JAMA 2014, 312, 1744-1753. [CrossRef]

151. Eggermont, A.M.; Chiarion-Sileni, V.; Grob, J.J.; Dummer, R.; Wolchok, J.D.; Schmidt, H.; Hamid, O.; Robert, C.; Ascierto, P.A.; Richards, J.M.; et al. Prolonged survival in stage iii melanoma with ipilimumab adjuvant therapy. N. Engl. J. Med. 2016, 375, 1845-1855. [CrossRef]

152. Schwarze, J.K.; Vandersleyen, V.; Awada, G.; Jansen, Y.; Seremet, T.; Neyns, B. A sequential dual cohort phase II clinical trial on adjuvant low-dose nivolumab with or without low-dose ipilimumab as adjuvant therapy following the resection of melanoma macrometastases (MM). J. Clin. Oncol. 2019, 37, 9585. [CrossRef]

153. Spicer, J.F.; Marabelle, A.; Baurain, J.; Awada, A.; Kristeleit, R.S.; Jossang, D.E.; Jebsen, N.; Loirat, D.; Armstrong, A.C.; Curigliano, G.; et al. A phase I/II study of the oncolytic peptide LTX-315 combined with checkpoint inhibition generates de novo T-cell responses and clinical benefit in patients with advanced solid tumors. J. Clin. Oncol. 2018, 36, 3094. [CrossRef]

154. Marabelle, A.; Baurain, J.; Awada, A.; Kristeleit, R.S.; Loirat, D.; Jossang, D.E.; Jebsen, N.L.; Sveinbjornsson, B.; Rekdal, O.; Gjerstad, V.S.; et al. A Phase I study of the oncolytic peptide LTX-315 generates de novo T-cell responses and clinical benefit in patients with advanced melanoma. In Proceedings of the American Association for Cancer Research Annual Meeting 2019, Atlanta, GA, USA, 29 March-3 April 2019. Abstract no: СТ069.

155. Hodi, F.S.; Chiarion-Sileni, V.; Gonzalez, R.; Grob, J.; Rutkowski, P.; Cowey, C.L.; Lao, C.D.; Schadendorf, D.; Wagstaff, J.; Dummer, R.; et al. Nivolumab plus ipilimumab or nivolumab alone versus ipilimumab alone in advanced melanoma (CheckMate 067): 4-year outcomes of a multicentre, randomised, phase 3 trial. Lancet Oncol. 2018, 19, 1480-1492. [CrossRef]

156. Callahan, M.K.; Kluger, H.; Postow, M.A.; Segal, N.H.; Lesokhin, A.; Atkins, M.B.; Kirkwood, J.M.; Krishnan, S.; Bhore, R.; Horak, C.; et al. Nivolumab plus ipilimumab in patients with advanced melanoma: Updated survival, response, and safety data in a phase I dose-escalation study. J. Clin. Oncol. 2018, 36, 391-398. [CrossRef] [PubMed]

157. Long, G.V.; Atkinson, V.; Lo, S.; Sandhu, S.; Guminski, A.D.; Brown, M.P.; Wilmott, J.S.; Edwards, J.; Gonzalez, M.; Scolyer, R.A.; et al. Combination nivolumab and ipilimumab or nivolumab alone in melanoma brain metastases: A multicentre randomised phase 2 study. Lancet Oncol. 2018, 19, 672-681. [CrossRef]

158. Atkins, M.B.; Hodi, F.S.; Thompson, J.A.; McDermott, D.F.; Hwu, W.J.; Lawrence, D.P.; Dawson, N.A.; Wong, D.J.; Bhatia, S.; James, M.; et al. Pembrolizumab plus pegylated interferon alfa-2b or ipilimumab for advanced melanoma or renal cell carcinoma: Dose-finding results from the phase Ib KEYNOTE-029 study. Clin. Cancer Res. 2018, 24, 1805-1815. [CrossRef] [PubMed]

159. Hodi, F.S.; Chesney, J.; Pavlick, A.C.; Robert, C.; Grossmann, K.F.; McDermott, D.F.; Linette, G.P.; Meyer, N.; Giguere, J.K.; Agarwala, S.S.; et al. Combined nivolumab and ipilimumab versus ipilimumab alone in patients with advanced melanoma: 2-year overall survival outcomes in a multicentre, randomised, controlled, phase 2 trial. Lancet Oncol. 2016, 17, 1558-1568. [CrossRef]

160. Weber, J.S.; Gibney, G.; Sullivan, R.J.; Sosman, J.A.; Slingluff, C.L., Jr.; Lawrence, D.P.; Logan, T.F.; Schuchter, L.M.; Nair, S.; Fecher, L.; et al. Sequential administration of nivolumab and ipilimumab with a planned switch in patients with advanced melanoma (CheckMate 064): An open-label, randomised, phase 2 trial. Lancet Oncol. 2016, 17, 943-955. [CrossRef] 
161. Vouri, M.; Hafizi, S. TAM receptor kinases in cancer drug resistance. Cancer Res. 2017, 77, $2755-2778$. [CrossRef]

162. Linger, R.M.A.; Keating, A.K.; Shelton Earp, H.; Graham, D.K. TAM receptor tyrosine kinases: Biologic functions, signaling, and potential therapeutic targeting in human cancer. Adv. Cancer Res. 2008, 100, $35-83$.

163. Corno, C.; Gatti, L.; Lanzi, C.; Zaffaroni, N.; Colombo, D.; Perego, P. Role of the receptor tyrosine kinase Axl and its targeting in cancer cells. Curr. Med. Chem. 2016, 23, 1496-1512. [CrossRef]

164. Rankin, E.; Giaccia, A.J. The receptor tyrosine kinase axl in cancer progression. Cancers 2016, 8, 103. [CrossRef]

165. Müller, J.; Krijgsman, O.; Tsoi,J.; Robert, L.; Hugo, W.; Song, C.; Kong, X.; Possik, P.A.; Cornelissen-Steijger, P.D.; Geukes Foppen, M.H.; et al. Low MITF/AXL ratio predicts early resistance to multiple targeted drugs in melanoma. Nat. Commun. 2014, 5, 5712. [CrossRef] [PubMed]

166. Uribe, D.J.; Mandell, E.K.; Watson, A.; Martinez, J.D.; Leighton, J.A.; Ghosh, S.; Rothlin, C.V. The receptor tyrosine kinase AXL promotes migration and invasion in colorectal cancer. PLoS ONE 2017, 12, e0179979. [CrossRef] [PubMed]

167. Park, I.K.; Mundy-Bosse, B.; Whitman, S.P.; Zhang, X.; Warner, S.L.; Bearss, D.J.; Blum, W.; Marcucci, G.; Caligiuri, M.A. Receptor tyrosine kinase Axl is required for resistance of leukemic cells to FLT3-targeted therapy in acute myeloid leukemia. Leukemia 2015, 29, 2382-2389. [CrossRef] [PubMed]

168. Goyette, M.A.; Duhamel, S.; Aubert, L.; Pelletier, A.; Savage, P.; Thibault, M.P.; Johnson, R.M.; Carmeliet, P.; Basik, M.; Gaboury, L.; et al. The receptor tyrosine kinase axl is required at multiple steps of the metastatic cascade during her2-positive breast cancer progression. Cell. Rep. 2018, 23, 1476-1490. [CrossRef] [PubMed]

169. Elkabets, M.; Pazarentzos, E.; Juric, D.; Sheng, Q.; Pelossof, R.A.; Brook, S.; Benzaken, A.O.; Rodon, J.; Morse, N.; Yan, J.J.; et al. Axl mediates resistance to PI3K $\alpha$ inhibition by activating the EGFR/PKC/mTOR axis in head and neck and esophageal squamous cell carcinomas. Cancer Cell 2015, 27, 533-546. [CrossRef] [PubMed]

170. Byers, L.A.; Diao, L.; Wang, J.; Saintigny, P.; Girard, L.; Peyton, M.; Shen, L.; Fan, Y.; Giri, U.; Tumula, P.K.; et al. An epithelial-mesenchymal transition gene signature predicts resistance to EGFR and PI3K inhibitors and identifies Axl as a therapeutic target for overcoming EGFR inhibitor resistance. Clin. Cancer Res. 2013, 19, 279-290. [CrossRef]

171. Zhang, Z.; Lee, J.C.; Lin, L.; Olivas, V.; Au, V.; LaFramboise, T.; Abdel-Rahman, M.; Wang, X.; Levine, A.D.; Rho, J.K.; et al. Activation of the AXL kinase causes resistance to EGFR-targeted therapy in lung cancer. Nat. Genet. 2012, 44, 852-860. [CrossRef]

172. Sensi, M.; Catani, M.; Castellano, G.; Nicolini, G.; Alciato, F.; Tragni, G.; De Santis, G.; Bersani, I.; Avanzi, G.; Tomassetti, A.; et al. Human cutaneous melanomas lacking MITF and melanocyte differentiation antigens express a functional Axl receptor kinase. J. Investig. Dermatol. 2011, 131, 2448-2457. [CrossRef]

173. Konieczkowski, D.J.; Johannessen, C.M.; Abudayyeh, O.; Kim, J.W.; Cooper, Z.A.; Piris, A.; Frederick, D.T.; Barzily-Rokni, M.; Straussman, R.; Haq, R.; et al. A melanoma cell state distinction influences sensitivity to MAPK pathway inhibitors. Cancer Discov. 2014, 4, 816-827. [CrossRef]

174. Ohanna, M.; Cheli, Y.; Bonet, C.; Bonazzi, V.F.; Allegra, M.; Giuliano, S.; Bille, K.; Bahadoran, P.; Giacchero, D.; Lacour, J.P.; et al. Secretome from senescent melanoma engages the STAT3 pathway to favor reprogramming of naive melanoma towards a tumor-initiating cell phenotype. Oncotarget 2013, 4, 2212-2224. [CrossRef]

175. Zhao, Z.; Wu, H.; Wang, J.; Liu, Y.; Knapp, S.; Liu, Q.; Gray, N.S. Exploration of Type II Binding Mode: A Privileged Approach for Kinase Inhibitor Focused Drug Discovery? ACS. Chem. Biol. 2014, 9, 1230-1241. [CrossRef] [PubMed]

176. BerGenBio. Bemcentinib, Melanoma. Available online: https://www.bergenbio.com/pipeline/bemcentinibmelanoma/ (accessed on 26 November 2019).

177. Straume, O.; Schuster, C.; Gausdal, G.; Lorens, J.; Gjertsen, B.T. A randomized phase Ib/II study of the selective small molecule axl inhibitor bemcentinib (BGB324) in combination with either dabrafenib/trametinib or pembrolizumab in patients with metastatic melanoma. J. Clin. Oncol. 2018, 36, 9548. [CrossRef]

178. Clinical trials.gov. First-in-human study of oral TP-0903 (a novel inhibitor of AXL kinase) in patients with advanced solid tumors (NCT02729298). Available online: https://clinicaltrials.gov/ct2/show/NCT02729298? term $=02729298 \&$ rank $=1$ (accessed on 26 November 2019). 
179. Sarantopoulos, J.; Shaalan Beg, M.; Fotopoulos, G.; Taverna, J.A.; Anthony, S.P.; Weitman, S.D.; Warner, S.L.; Mouritsen, L.; Bearss, D.; Smith, S.; et al. A phase 1a/1b first-in-human, open-label, dose-escalation, safety, pharmacokinetic, and pharmacodynamic study of oral TP-0903, a potent inhibitor of AXL kinase, administered daily for 21 days to patients with advanced solid tumors. J. Clin. Oncol. 2018, 36. [CrossRef]

180. Exelixis. Cabozantinib development program. Available online: https:/www.exelixis.com/cabozantinibdevelopment-program/ (accessed on 26 November 2019).

181. Daud, A.; Kluger, H.M.; Kurzrock, R.; Schimmoller, F.; Weitzman, A.L.; Samuel, T.A.; Moussa, A.H.; Gordon, M.S.; Shapiro, G.I. Phase II randomised discontinuation trial of the MET/VEGF receptor inhibitor cabozantinib in metastatic melanoma. Br. J. Cancer 2017, 116, 432-440. [CrossRef] [PubMed]

182. Clinical trials.gov. Cabozantinib and pembrolizumab for advanced metastatic melanoma. Available online: https://clinicaltrials.gov/ct2/show/NCT03957551?term=03957551\&rank=1 (accessed on 26 November 2019).

183. Paolino, M.; Choidas, A.; Wallner, S.; Pranjic, B.; Uribesalgo, I.; Loeser, S.; Jamieson, A.M.; Langdon, W.Y.; Ikeda, F.; Fededa, J.P.; et al. The E3 Ligase Cbl-b and TAM receptors regulate cancer metastasis via natural killer cells. Nature 2014, 507, 508-512. [CrossRef] [PubMed]

184. Boshuizen, J.; Koopman, L.A.; Krijgsman, O.; Shahrabi, A.; van den Heuvel, E.G.; Ligtenberg, M.A.; Vredevoogd, D.W.; Kemper, K.; Kuilman, T.; Song, J.Y.; et al. Cooperative targeting of melanoma heterogeneity with an AXL antibody-drug conjugate and BRAF/MEK inhibitors. Nat. Med. 2018, 24, 203-212. [CrossRef] [PubMed]

185. Clinical trials.gov. Enapotamab vedotin (HuMax-AXL-ADC) safety study in patients with solid tumors. Available online: https://clinicaltrials.gov/ct2/show/NCT02988817 (accessed on 26 November 2019).

186. Flaherty, K.T.; Puzanov, I.; Kim, K.B.; Ribas, A.; McArthur, G.A.; Sosman, J.A.; O’Dwyer, P.J.; Lee, R.J.; Grippo, J.F.; Nolop, K.; et al. Inhibition of mutated, activated BRAF in metastatic melanoma. N. Engl. J. Med. 2010, 363, 809-819. [CrossRef]

187. Ascierto, P.A.; Kirkwood, J.M.; Grob, J.; Simeone, E.; Grimaldi, A.M.; Maio, M.; Palmieri, G.; Testori, A.; Marincola, F.M.; Mozzillo, N. The role of BRAF V600 mutation in melanoma. J. Transl. Med. 2012, 10, 85. [CrossRef]

188. Chapman, P.B.; Hauschild, A.; Robert, C.; Haanen, J.B.; Ascierto, P.; Larkin, J.; Dummer, R.; Garbe, C.; Testori, A.; Maio, M.; et al. Improved Survival with Vemurafenib in Melanoma with BRAF V600E Mutation. N. Engl. J. Med. 2011, 364, 2507-2516. [CrossRef]

189. Menzies, A.M.; Long, G.V.; Murali, R. Dabrafenib and its potential for the treatment of metastatic melanoma. Drug Des. Dev. Ther. 2012, 6, 391-405.

190. Ascierto, P.A.; Minor, D.; Ribas, A.; Lebbe, C.; O’Hagan, A.; Guckert, N.A.; Schadernorf, D.; Kefford, R.F.; Grob, J.; Hamid, O.; et al. Phase II trial (BREAK-2) of the BRAF inhibitor dabrafenib (GSK2118436) in patients with metastatic melanoma. J. Clin. Oncol. 2013, 31, 3205-3211. [CrossRef] [PubMed]

191. Novartis. Tafinlar and Mekinist- Dosing \& Administration. Available online: https://www.hcp.novartis.com/ products/tafinlar-mekinist/advanced-melanoma/dosing-and-administration/ (accessed on 27 January 2020).

192. U.S. FDA. FDA approves encorafenib and binimetinib in combination for unresectable or metastatic melanoma with BRAF mutations. Available online: https:/www.fda.gov/drugs/resources-information-approved-drugs/ fda-approves-encorafenib-and-binimetinib-combination-unresectable-or-metastatic-melanoma-braf (accessed on 26 November 2019).

193. Clinical trials.gov. Sequential Combo Immuno and Target Therapy (SECOMBIT) Study (SECOMBIT). Available online: https://clinicaltrials.gov/ct2/show/NCT02631447 (accessed on 26 November 2019).

194. Clinical trials.gov. LGX818 and MEK162 in combination with a third agent (BKM120, LEE011, BGJ398 or INC280) in advanced BRAF melanoma (LOGIC-2). Available online: https://clinicaltrials.gov/ct2/show/ NCT02159066 (accessed on 26 November 2019).

195. Grimaldi, A.M.; Simeone, E.; Festino, L.; Vanella, V.; Strudel, M.; Ascierto, P.A. MEK inhibitors in the treatment of metastatic melanoma and solid tumors. Am. J. Clin. Dermatol. 2017, 18, 745-754. [CrossRef] [PubMed]

196. Infante, J.R.; Fecher, L.A.; Falchook, G.S.; Nallapareddy, S.; Gordon, M.S.; Becerra, C.; DeMarini, D.J.; Cox, D.S.; Xu, Y.; Morris, S.R.; et al. Safety, pharmacokinetic, pharmacodynamic, and efficacy data for the oral MEK inhibitor trametinib: A phase 1 dose-escalation trial. Lancet Oncol. 2012, 13, 773-781. [CrossRef] 
197. Long, G.V.; Flaherty, K.T.; Stroyakovskiy, D.; Gogas, H.; Levchenko, E.; de Braud, F.; Larkin, J.; Garbe, C.; Jouary, T.; Hauschild, A.; et al. Dabrafenib plus trametinib versus dabrafenib monotherapy in patients with metastatic BRAF V600E/K-mutant melanoma: Long-term survival and safety analysis of a phase 3 study. Ann. Oncol. 2017, 28, 1631-1639. [CrossRef] [PubMed]

198. Ascierto, P.A.; McArthur, G.A.; Dréno, B.; Atkinson, V.; Liszkay, G.; Di Giacomo, A.M.; Mandalà, M.; Demidov, L.; Stroyakovskiy, D.; Thomas, L.; et al. Cobimetinib combined with vemurafenib in advanced BRAF(V600)-mutant melanoma (coBRIM): Updated efficacy results from a randomised, double-blind, phase 3 trial. Lancet Oncol. 2016, 17, 1248-1260. [CrossRef]

199. Cheng, Y.; Wang, X.; Xia, X.; Zhang, W.; Tian, H. A benzoxazole compound as a novel MEK inhibitor for the treatment of RAS/RAF mutant cancer. Int. J. Cancer 2019, 145, 586-596. [CrossRef]

200. Goto, M.; Chow, J.; Muramoto, K.; Chiba, K.; Yamamoto, S.; Fujita, M.; Obaishi, H.; Tai, K.; Mizui, Y.; Tanaka, I.; et al. E6201 [(3S,4R,5Z,8S,9S,11E)-14-(ethylamino)-8, 9,16-trihydroxy-3,4-dimethyl3,4,9,19-tetrahydro-1H-2-benzoxacyclotetradecine-1,7(8H)-dione], a novel kinase inhibitor of mitogen-activated protein kinase/extracellular signal-regulated kinase kinase (MEK)-1 and MEK kinase-1: In vitro characterization of its anti-inflammatory and antihyperproliferative activities. J. Pharmacol. Exp. Ther. 2009, 331, 485-495.

201. Tibes, R.; Borad, M.J.; Dutcus, C.E.; Reyderman, L.; Feit, K.; Eisen, A.; Verbel, D.A.; Von Hoff, D.D. Safety, pharmacokinetics, and preliminary efficacy of E6201 in patients with advanced solid tumours, including melanoma: Results of a phase 1 study. Br. J. Cancer 2018, 118, 1580-1585. [CrossRef]

202. Micel, L.N.; Tentler, J.J.; Tan, A.C.; Selby, H.M.; Brunkow, K.L.; Robertson, K.M.; Davis, S.L.; Klauck, P.J.; Pitts, T.M.; Gangolli, E.; et al. Antitumor activity of the MEK inhibitor TAK-733 against melanoma cell lines and patient-derived tumor explants. Mol. Cancer Ther. 2015, 14, 317-325. [CrossRef]

203. Adjei, A.A.; LoRusso, P.; Ribas, A.; Sosman, J.A.; Pavlick, A.; Dy, G.K.; Zhou, X.; Gangolli, E.; Kneissl, M.; Faucette, S.; et al. A phase I dose-escalation study of TAK-733, an investigational oral MEK inhibitor, in patients with advanced solid tumors. Investig. New Drugs 2017, 35, 47-58. [CrossRef]

204. Ciuffreda, L.; Bufalo, D.D.; Desideri, M.; Sanza, C.D.; Stoppacciaro, A.; Ricciardi, M.R.; Chiaretti, S.; Tavolaro, S.; Benassi, B.; Bellacosa, A.; et al. Growth-inhibitory and antiangiogenic activity of the MEK inhibitor PD0325901 in malignant melanoma with or without BRAF mutations. Neoplasia 2009, 11, 720-731. [CrossRef] [PubMed]

205. Boasberg, P.D.; Redfern, C.H.; Daniels, G.A.; Bodkin, D.; Garrett, C.R.; Ricart, A.D. Pilot study of PD-0325901 in previously treated patients with advanced melanoma, breast cancer, and colon cancer. Cancer Chemother. Pharmacol. 2011, 68, 547-552. [CrossRef] [PubMed]

206. Ramos, J.W. The regulation of extracellular signal-regulated kinase (ERK) in mammalian cells. Int. J. Biochem. Cell. Biol. 2008, 40, 2707-2719. [CrossRef] [PubMed]

207. Germann, U.A.; Furey, B.F.; Markland, W.; Hoover, R.R.; Aronov, A.M.; Roix, J.J.; Hale, M.; Boucher, D.M.; Sorrell, D.A.; Martinez-Botella, G.; et al. Targeting the MAPK signaling pathway in cancer: Promising preclinical activity with the novel selective ERK1/2 inhibitor BVD-523 (Ulixertinib). Mol. Cancer Ther. 2017, 16, 2351-2363. [CrossRef]

208. Sullivan, R.J.; Infante, J.R.; Janku, F.; Wong, D.J.L.; Sosman, J.A.; Keedy, V.; Patel, M.R.; Shapiro, G.I.; Mier, J.W.; Tolcher, A.W.; et al. First-in-Class ERK1/2 inhibitor ulixertinib (BVD-523) in patients with MAPK mutant advanced solid tumors: Results of a phase I dose-escalation and expansion study. Cancer Discov. 2018, 8, 184-195. [CrossRef]

209. Clinical trials.gov. A study of LY3214996 administered alone or in combination with other agents in participants with advanced/metastatic cancer (NCT02857270). Available online: https:/clinicaltrials.gov/ct2/ show/NCT02857270 (accessed on 26 November 2019).

210. Pant, S.; Bendell, J.C.; Sullivan, R.J.; Shapiro, G.; Millward, M.; Mi, G.; Yuen, E.; Willard, M.D.; Wang, D.; Joseph, S.; et al. A phase I dose escalation (DE) study of ERK inhibitor, LY3214996, in advanced (adv) cancer (CA) patients (pts). J. Clin. Oncol. 2019, 37, 3001. [CrossRef]

211. Clinical trials.gov. Study of MK-8353 + Selumetinib in advanced/metastatic solid tumors (MK-8353-014) (NCT03745989). Available online: https://clinicaltrials.gov/ct2/show/NCT03745989 (accessed on 26 November 2019). 
212. Clinical trials.gov. Study of MK-8353 in combination with pembrolizumab (MK-3475) in participants with advanced malignancies (MK-8353-013) (NCT02972034). Available online: https://clinicaltrials.gov/ct2/show/ NCT02972034 (accessed on 26 November 2019).

213. Moschos, S.J.; Sullivan, R.J.; Hwu, W.J.; Ramanathan, R.K.; Adjei, A.A.; Fong, P.C.; Shapira-Frommer, R.; Tawbi, H.A.; Rubino, J.; Rush, T.S.; et al. Development of MK-8353, an orally administered ERK1/2 inhibitor, in patients with advanced solid tumors. JCI Insight 2018, 3. [CrossRef]

214. Clinical trials.gov. A phase I clinical study with investigational compound LTT462 in adult patients with specific advanced cancers (NCT02711345). Available online: https://clinicaltrials.gov/ct2/show/NCT02711345 (accessed on 26 November 2019).

215. Burrows, F.; Kessler, L.; Chen, J.; Gao, X.; Hnsen, R.; Li, S.; Thach, C.; Darjania, L.; Yao, Y.; Wang, Y.; et al. KO-947, a potent ERK inhibitor with robust preclinical single agent activity in MAPK pathway dysregulated tumors. In Proceedings of the American Association for Cancer Research Annual Meeting 2017, Washington, DC, USA, 1-5 April 2017. Abstract no: 5168.

216. Blake, J.; Burkard, M.; Chan, J.; Chen, H.; Chou, K.; Diaz, D.; Dudley, D.A.; Gaudino, J.J.; Gould, S.E.; Grina, J.; et al. Discovery of (S)-1-(1-(4-Chloro-3-fluorophenyl)-2-hydroxyethyl)4-(2-((1-methyl-1H-pyrazol-5-yl)amino)pyrimidin-4-yl)pyridin-2(1H)-one (GDC-0994), an extracellular signal-regulated kinase 1/2 (erk1/2) inhibitor in early clinical development. J. Med. Chem. 2016, 59, 5650-5660. [CrossRef]

217. Varja, A.; Soria, J.C.; Hollebecque, A.; LoRusso, P.; Vaishampayan, U.; Okrah, K.; Huang, S.M.A.; Murray, E.; Sanabria-Bohorquez, S.; Tagen, M.; et al. A first-in-human phase I study to evaluate the ERK1/2 inhibitor GDC-0994 in patients with advanced solid tumors. Eur. J. Cancer 2016, 69, S11. [CrossRef]

218. Clinical trials.gov. A study of the safety, tolerability, and effects of cobimetinib and GDC-0994 in patients with locally advanced or metastatic solid tumors (NCT02457793). Available online: https://clinicaltrials.gov/ ct2/show/NCT02457793 (accessed on 26 November 2019).

219. Morris, E.J.; Jha, S.; Restaino, C.R.; Dayananth, P.; Zhu, H.; Cooper, A.; Carr, D.; Deng, Y.; Jin, W.; Black, S.; et al. Discovery of a novel ERK inhibitor with activity in models of acquired resistance to BRAF and MEK inhibitors. Cancer Discov. 2013, 3, 742-750. [CrossRef]

220. Wong, D.J.; Robert, L.; Atefi, M.S.; Lassen, A.; Avarappatt, G.; Cerniglia, M.; Avramis, E.; Tsoi, J.; Foulad, D.; Graeber, T.G.; et al. Antitumor activity of the ERK inhibitor SCH772984 against BRAF mutant, NRAS mutant and wild-type melanoma. Mol. Cancer 2014, 13, 194. [CrossRef] [PubMed]

221. Xue, Y.; Martelotto, L.; Baslan, T.; Vides, A.; Solomon, M.; Mai, T.T.; Chaudhary, N.; Riely, G.J.; Li, B.T.; Scott, K.; et al. An approach to suppress the evolution of resistance in BRAFV600E -mutant cancer. Nat. Med. 2017, 23, 929-937. [CrossRef] [PubMed]

222. Delord, J.; Robert, C.; Nyakas, M.; McArthur, G.A.; Kudchakar, R.; Mahipal, A.; Yamada, Y.; Sullivan, R.; Arance, A.; Kefford, R.F.; et al. Phase I dose-escalation and -expansion study of the BRAF inhibitor encorafenib (LGX818) in metastatic BRAF-mutant melanoma. Clin. Cancer Res. 2017, 23, 5339-5348. [CrossRef] [PubMed]

223. Kefford, R.; Sullivan, R.J.; Miller, W.H.; Elez, E.M.; Tan, D.; Kim, K.B.; Long, G.V.; Flaherty, K.T.; Tai, D.; Stutvoet, S.; et al. Phase Ib/II, open-label, dose-escalation study of LGX818, an oral selective BRAF inhibitor, in combination with MEK162, an oral MEK1/2 inhibitor, in patients with BRAF V600-dependent advanced solid tumors: Preliminary results. J. Transl. Med. 2014, 12, P5. [CrossRef]

224. Dummer, R.; Ascierto, P.A.; Gogas, H.J.; Arance, A.; Mandala, M.; Liszkay, G.; Garbe, C.; Schadendorf, D.; Krajsova, I.; Gutzmer, R.; et al. Overall survival in patients with BRAF-mutant melanoma receiving encorafenib plus binimetinib versus vemurafenib or encorafenib (COLUMBUS): A multicentre, open-label, randomised, phase 3 trial. Lancet Oncol. 2018, 19, 1315-1327. [CrossRef]

225. Brieger, K.; Schiavone, S.; Miller, F.J., Jr.; Krause, K.H. Reactive oxygen species: From health to disease. Swiss. Med. Wkly. 2012, 142, w13659. [CrossRef]

226. Kawanishi, S.; Hiraku, Y.; Pinlaor, S.; Ma, N. Oxidative and nitrative DNA damage in animals and patients with inflammatory diseases in relation to inflammation-related carcinogenesis. Biol. Chem. 2006, 387, 365-372. [CrossRef]

227. Szatrowski, T.P.; Nathan, C.F. Production of large amounts of hydrogen peroxide by human tumor cells. Cancer Res. 1991, 51, 794-798.

228. Hileman, E.O.; Liu, J.; Albitar, M.; Keating, M.J.; Huang, P. Intrinsic oxidative stress in cancer cells: A biochemical basis for therapeutic selectivity. Cancer Chemother. Pharmacol. 2004, 53, 209-219. [CrossRef] 
229. Peng, X.; Gandhi, V. ROS-activated anticancer prodrugs: A new strategy for tumor-specific damage. Ther. Deliv. 2012, 3, 823-833. [CrossRef]

230. Corazao-Rozas, P.; Guerreschi, P.; Jendoubi, M.; André, F.; Jonneaux, A.; Scalbert, C.; Garçon, G.; Malet-Martino, M.; Balayssac, S.; Rocchi, S.; et al. Mitochondrial oxidative stress is the Achille's heel of melanoma cells resistant to Braf-mutant inhibitor. Oncotarget 2013, 4, 1986-1998. [CrossRef] [PubMed]

231. Kim, E.; Bhuniya, S.; Lee, H.; Kim, H.M.; Cheong, C.; Maiti, S.; Hong, K.S.; Kim, J.S. An activatable prodrug for the treatment of metastatic tumors. J. Am. Chem. Soc. 2014, 136, 13888-13894. [CrossRef] [PubMed]

232. Wang, M.; Sun, S.; Neufeld, C.I.; Perez-Ramirez, B.; Xu, Q. Reactive oxygen species-responsive protein modification and its intracellular delivery for targeted cancer therapy. Angew. Chem. Int. Ed. Engl. 2014, 53, 13444-13448. [CrossRef] [PubMed]

233. Yuan, L.; Mishra, R.; Patel, H.; Abdulsalam, S.; Greis, K.D.; Kadekaro, A.L.; Merino, E.J.; Garrett, J.T. Utilization of reactive oxygen species targeted therapy to prolong the efficacy of BRAF inhibitors in melanoma. J. Cancer 2018, 9, 4665-4676. [CrossRef] [PubMed]

234. Thowfeik, F.S.; AbdulSalam, S.F.; Wunderlich, M.; Wyder, M.; Greis, K.D.; Kadekaro, A.L.; Mulloy, J.C.; Merino, E.J. A ROS-Activatable agent elicits homologous recombination DNA repair and synergizes with pathway compounds. ChemBioChem 2015, 16, 2513-2521. [CrossRef] [PubMed]

(C) 2020 by the authors. Licensee MDPI, Basel, Switzerland. This article is an open access article distributed under the terms and conditions of the Creative Commons Attribution (CC BY) license (http://creativecommons.org/licenses/by/4.0/). 